\title{
WestVirginiaUniversity
}

THE RESEARCH REPOSITORY @ WVU

Graduate Theses, Dissertations, and Problem Reports

2004

\section{Origins and the twentieth-century long poem}

Joe W. Moffett

West Virginia University

Follow this and additional works at: https://researchrepository.wvu.edu/etd

\section{Recommended Citation}

Moffett, Joe W., "Origins and the twentieth-century long poem" (2004). Graduate Theses, Dissertations, and Problem Reports. 2084.

https://researchrepository.wvu.edu/etd/2084

This Dissertation is protected by copyright and/or related rights. It has been brought to you by the The Research Repository @ WVU with permission from the rights-holder(s). You are free to use this Dissertation in any way that is permitted by the copyright and related rights legislation that applies to your use. For other uses you must obtain permission from the rights-holder(s) directly, unless additional rights are indicated by a Creative Commons license in the record and/ or on the work itself. This Dissertation has been accepted for inclusion in WVU Graduate Theses, Dissertations, and Problem Reports collection by an authorized administrator of The Research Repository @ WVU.

For more information, please contact researchrepository@mail.wvu.edu. 


\title{
Origins and the Twentieth-Century Long Poem
}

\author{
Joe W. Moffett \\ Dissertation submitted to the \\ Eberly College of Arts and Sciences \\ at West Virginia University \\ in partial fulfillment of the requirements \\ for the degree of
}
Doctor of Philosophy
in
English

\author{
Brian McHale, Ph.D., Chair \\ Dennis Allen, Ph.D. \\ Patrick W. Conner Ph.D. \\ Kathleen McNerney, Ph.D. \\ Lisa Weihman, Ph.D.
}

Department of English
Morgantown, West Virginia 2004

Keywords: Long Poem, Origins, Modernism, Postmodernism, Popular Culture, Postcolonialism, Nationalism, Judy Grahn, Derek Walcott, Geoffrey Hill 


\title{
Abstract \\ Origins and the Twentieth-Century Long Poem
}

\author{
Joe W. Moffett
}

The long poem is often seen by critics as beginning in the nineteenth-century with the publication of Walt Whitman's Song of Myself. It is generally agreed, however, that the form did not come of age until the following century when it became a premier poetic endeavor. Although the long poem has been used to various ends, one theme identifiable among a variety of twentieth-century texts is a concern with origins. In this dissertation poets are seen as seeking to evaluate the societies in which they live by looking into the past to find originary cultures from which their own descend. Employing the insights of Jacques Derrida, Judith Butler, and Edward W. Said, an overview of the concept of the origin in contemporary critical theory is offered. Three specific "originary moments" are then discussed: the Sumerian, the Homeric, and the Anglo-Saxon. Poets such as Ezra Pound, Louis Zukofsky, Charles Olson, Louise Glück, H.D., and Basil Bunting who examine these originary moments are surveyed in the introduction. The main contention is that the search for origins common among modernist poets from the first half of the century is reenvisioned by writers from the latter decades of the century. Although the relatively unguarded appropriation of originary moments among modernists is scrutinized by postmodernists, origins are clearly still a serious consideration in postmodernism and thus there can be seen to be some continuity in the last century's poetic practices. The body chapters include an analysis of Judy Grahn's use of Sumerian myth and contemporary popular culture in A Chronicle of Queens to construct her own origin story, a reading of Derek Walcott's Omeros that explores his ambivalence for European origins in light of the postcolonial situation of his native Caribbean island of St. Lucia, and Geoffrey Hill's repudiation of origin-seeking in attempts to view Anglo-Saxon England as the origin of the modern British nation in his Mercian Hymns. These three writers are taken to represent the tendency in postmodern poetics to evaluate the implications of originary thinking in modernism. 


\section{Acknowledgements}

Any extended project such as this one incurs the debt of many people, whom it gives me great pleasure to thank:

I want to first acknowledge the Stephen F. Crocker Dissertation Fellowship provided to me by the West Virginia University Department of English which enabled the timely completion of this project.

Mary Ann Samyn deserves thanks for providing me with initial bibliographical suggestions, as does Sandy Baldwin who went out of his way to look at an early plan for this project. My thanks go to Gerry LaFemina for being kind enough to read through this dissertation in its first rough state and for helping me to refine my thinking.

I want to thank each of my committee members:

Dennis Allen for taking the time to carefully review each of my chapters at the different stages of this process and for getting me back on course when I would run afoul. His early guidance was instrumental in the successful completion of this project.

Patrick W. Conner for suffering through two semesters of faulty but inspired Old English translations from me and for recommending the book Desire for Origins by Allen Frantzen which inspired my approach here.

Kathleen McNerney, whose acute critical eye caught many more typographical errors than I would ever care to admit made their way into drafts of this work.

Lisa Weihman for being an enthusiastic and empathetic figure throughout the writing and research that went into this dissertation.

I must express my appreciation to the Chair of my committee, Brian McHale, who through a number of graduate courses, a Master's thesis, and this dissertation showed me 
no end of generosity with his knowledge, time, and guidance. It pleases me greatly to have him with me at the end of my formal education.

I want to acknowledge the support extended to me, in a various ways, by my mother-in-law Ann Ritter and my father-in-law Neil Ritter.

I must thank my own parents, Joe and Darla Moffett, as well as my sister Cheyenne, for offering me nothing but love and encouragement in all my endeavors. My son, Devon, merits recognition for making certain that I balance the world of academia with that of toys and plenty of cartoons.

I dedicate my work on this project to my wife, Kelly, who was there from the beginning. 


\section{Table of Contents}

Chapter 1: "Returning to the Origin and Bringing Something Back": The Twentieth-

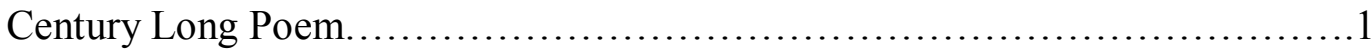

Chapter 2: “A New Myth of Origins": Judy Grahn's Chronicle of Queens and Popular

Culture. .38

Chapter 3: "Master, I Was the Freshest of All Your Readers": Derek Walcott's Omeros and Homer as Literary Origin......

Chapter 4: Narrating the Origins of the Nation: Geoffrey Hill's Mercian Hymns and

"An Apology for the Revival of Christian Architecture in England". 100

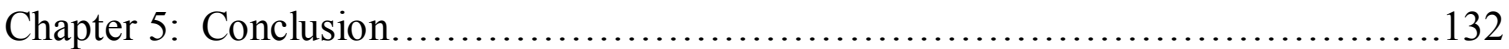

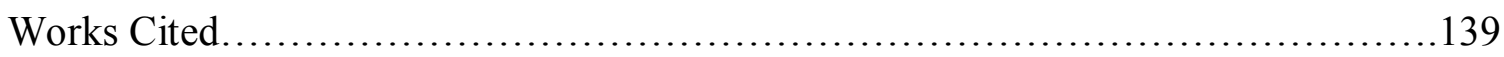

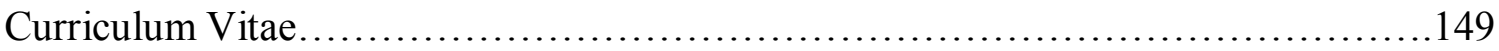




\section{Chapter One}

\section{"Returning to the Origin and Bringing Something Back": The Twentieth- Century Long Poem}

\section{The Legacy of the Long Poem and the Search for Origins}

In 1922 T.S. Eliot's "The Waste Land" set a precedent for literature in the twentieth-century. While encapsulating the anxiety, isolation, confusion, and other qualities that characterize the ethos of modernism across media, the poem also made its very form an issue. The fragmentation of thought and language which Eliot employed in his text became a hallmark of Anglo-American modernism (and by some accounts postmodernism), and an enduring feature of the form we think of as the long poem. While traditional narrative has returned as a viable option in many postmodern long poems, as Marjorie Perloff anticipates in The Dance of the Intellect, ${ }^{1}$ Eliot's text, and the many others that imitated it, used narrative fragmentation to mirror the problems of the modern world, especially modernity's ability to produce feelings of alienation and desperation in the individual. The very capaciousness of the long poem allowed it to be a device well suited to capturing contemporary history as it was experienced by Eliot and modernism's other canonical figures, such as Ezra Pound in The Cantos (1970) and William Carlos Williams in Paterson (1963).

Eliot was less an innovator than he might seem, however. While he certainly influenced several succeeding generations of writers through his content and his form,

\footnotetext{
${ }^{1}$ The seventh chapter of Perloff's book is entitled "From Image to Action: the Return of Story in Postmodern Poetry." Aside from the one narratively-based long poem Perloff examines, Edward Dorn's Gunslinger (1975), we might also cite Rita Dove's Thomas and Beulah (1986), Thomas McGrath's Letter to an Imaginary Friend (1997), and Paul Muldoon's Madoc: A Mystery (1991) as poems which revive story-telling in postmodern poetry. We will study a narrative-driven long poem in chapter three: Derek Walcott's Omeros (1990).
} 
Walt Whitman is typically seen as the progenitor of the American long poem. ${ }^{2}$ If we consider Whitman's "Song of Myself" as perhaps the first modern (if not modernist) long poem, we should concentrate on the early 1855 version, not the 1892 "deathbed" edition that usually finds its way into anthologies and collections of Whitman's work. ${ }^{3}$ The 1892 version has its merits: it is well formed and clearly demarcated by conventional sections and beginnings and endings. The 1855 version, on the other hand, lacks all of this. Instead the work is formless and bereft of the mannered trappings of Whitman's later interventions and stylizations. Roy Harvey Pearce remarked in 1961 that Whitman wrote an "[a]n American equivalent of an epic" (83). But it was not Homer's or Virgil's or even Milton's epic he produced. Instead we can now see him as the first writer of the form that would become known as the twentieth-century long poem. ${ }^{4}$

Like the epic, which, from Virgil to Dante, from Milton to Tennyson, has been the measure of a poet's lifework through the ages, the long poem has attained a premier place in modern literature. John Berryman jokes that, "[t]he only happy people in the world / are those who do not have to write long poems: / muck, administration, toil" (376, Berryman's caesura). The long poem shares affinities with epic, such as its use by poets

\footnotetext{
${ }^{2}$ Recent work has begun to reevaluate what has been the almost exclusively male-centered genre of the long poem. Susan Stanford Friedman identifies "four self-authorizing strategies" women adopt in using the form -- "the ironist, historicist, re-visionist, and experimentalist" (21) -- in their attempts to "feminize the genre" (12). We will see Judy Grahn occupying Friedman's second category, "the revisionist," in chapter two. Lynn Keller's Forms of Expansion is a full-length study of the long poem as it has been practiced by women writers. Keller believes that "precisely because [the long poem] has been so dominated by men, [it] offers - as genres like the novel or lyric, say, cannot - unusually unobstructed perspectives for viewing women's interactions with male-dominated traditions" (16-17).

${ }^{3}$ The Library of America edition (1992) of Whitman's Leaves of Grass publishes the first (1855) and last (1892) versions of the book together. Their juxtaposition shows the earlier, more "modernist" Whitman taming his verse into sections and inserting poeticisms as time goes on.

${ }^{4}$ Whitman's influence of course has been pervasive. Thomas Gardner chronicles his impact on a number of contemporary American poets - John Berryman, James Merrill, John Ashbery, among others - in his book Discovering Ourselves in Whitman: The Contemporary American Long Poem. Jeffrey Walker's Bardic Ethos and the American Epic Poem looks at Whitman's influence on later poets in terms of the public voice they assume. He writes, "my interest lies less with the possible orality or 'oratoricality' of the bardic voice, and more with its broad rhetorical function as an instrument of ethical authority" (xiii).
} 
as a vehicle for public debate, its expansiveness, its centering on a solitary figure or narrator. In fact these resemblances have led Michael André Bernstein to write on what he calls the "modern verse epic." ${ }^{5}$ Bernstein emphasizes the "epic" nature of the poems written by Pound, Williams, and Charles Olson in the last century and he is no doubt correct: their poems do seek to embody reinvigorated, modern versions of the epic. We lose sight of the place of these poems in Anglo-American literature, however, if we label them only as modern verse epics. They are in fact long poems which exhibit epic tendencies. This is a more fruitful distinction. ${ }^{6}$

M.L. Rosenthal and Sally Gall have similarly sought to deepen our appreciation of the long form in poetic writing. They attempt to do so by speaking of the "modern poetic sequence." This approach allows them to include the works of poets such as W.B. Yeats and Emily Dickinson who are otherwise excluded from discussions of the epic or the long poem. Modernist works like Wallace Stevens' Notes Toward a Supreme Fiction (1942) and George Oppen's Of Being Numerous (1968), with the discreet beginnings and endings of each of their sections, might benefit from being considered as sequences. Nevertheless, we must question if the term "modern poetic sequence" is not too far ranging in its implications to be of great use. Surely most long poetic works have a more tightly woven structure than the term "sequence" suggests, and evidence that a poet like Dickinson, for instance, had in mind a sequence when she was writing is debatable.

\footnotetext{
${ }^{5}$ Bernstein admits that the qualities of the epic only offer a "provisional, heuristic value" (15) to his discussion. He nevertheless presents a four-point rubric for the epic, the first and most important of which - "the epic presents a narrative of its audience's own cultural, historical, or mythic heritage, providing models of exemplary conduct (both good and bad) by which its readers can regulate their lives and adjust their shared customs" (14) - applies to a minority of long poems; most clearly reject overt didacticism. ${ }^{6}$ Another way of thinking about the legacy of the epic is to adopt Franco Moretti's suggestion in Modern Epic: The World System from Goethe to García Márquez, that the epic has become a "supercanonical form," and that it has had as much bearing on the novel as it has had on poetry in the last two centuries (4).
} 
Margaret Dickie claims that the long poem is synonymous with American modernism. She writes, "what is American Modernism? It is the long writing of the long poem" (162). Dickie rests with the term "long poem" because she believes the form is "long in the time of composition, in the initial intention, and in the final form"; she concludes, "the Modernist long poem is concerned first and last with its own length" (6). "Long poem" appears to strike a fair compromise between the inclusiveness of "modern poetic sequence" and the exclusiveness of "modern verse epic": it asks us to think of poems in terms of their ambition and physical size rather than focusing on their resemblances to narrative - (epic) or lyric -based (sequence) forms. In fact the long poem can be viewed as a mélange of these two traditions. Beyond its sheer bulk, the long poem lacks strict generic conventions: it does not need to develop character or plot as the novel does; it is not so constricted by compressed space as the lyric, or so constrained by its need to develop the "I"; it does not need to follow any strictly linear progression of thought as we expect of expository prose. It may hold affinities with the epic, but it is not restrained by epic conventions.

This form that Octavio Paz has alternatively labeled the "extensive poem" has been used variously by poets of the last century (7). Texts such as Hart Crane's The Bridge (1930) or Galway Kinnell's The Book of Nightmares (1971) pick up where Whitman left off by assessing the place of poetry in a democratic culture. Other works examine the psychological pressure on the individual in contemporary society, such as the so-called "confessional" poetics of Berryman in The Dream Songs (1969). Issues of

\footnotetext{
${ }^{7}$ In a special issue of Genre on the long poem, however, Charles Altieri argues we must account for the lyric impulse of the long poem: "[t]he most distinctive feature of the modernist long poem is the desire to achieve epic breadth by relying on structural principles inherent in lyric rather than narrative modes," he writes (653).
} 
gender are explored in The Meadowlands (1996) by Louise Glück and The Queen of Wands (1982) by Judy Grahn, both of which I will examine later. The long poem has been a vital force in poetry associated with language play and polysemy, from Louis Zukofsky's “A” (1978) to Charles Bernstein's "The Lives of the Toll Takers" (1994) and Susan Howe's The Europe of Trusts (1990). ${ }^{8}$ This is only to hint at the wide array of subject matter and approaches evident in the long poem in the last century.

Although the long poem is heterogeneous in character, one theme we can observe running throughout twentieth-century texts in various manifestations is a search for origins. The OED postulates that the English word "origin" derives from the French "origine" and dates from around 1512. The OED's second definition is the one most applicable to our purposes: "[t]hat from which anything arises, springs or is derived; source." When I say long poems are engaged in a search for origins I mean that they attempt to use origin or "source" cultures as a way to examine their own present cultures and social conditions. A partial list of long poems concerned with this theme would include H.D.'s Helen in Egypt (1961), Basil Bunting's Briggflatts (1965), Geoffrey Hill's Mercian Hymns (1971), and Derek Walcott's Omeros (1990). I will look at these texts, as well as a number of others, later in this chapter.

Some poets declare their search for origins directly. Seamus Heaney remarks in his short poem "Kinship," "I step through origins / like a dog turning / its memories of wilderness on the kitchen mat" (Poems 195). Indeed the term "origin" often conjures up images of a primal state, one from which the present moment is presumed to descend.

\footnotetext{
${ }^{8}$ Joseph Conte has examined the long poem as it appears among more experimental writers such as these in Unending Design. He abandons the term "long poem" and instead decides to speak of "serial" and "procedure" forms which he notes are "strictly postmodern innovations" (3). The narrowness of his focus makes his terms difficult to apply to our study here.
} 
We might say that the search for origins entails a fundamental inquiry into the past. It asks questions like where did we come from? is the present really a progression from the past? is there any way for us to fully comprehend that which came before us? It also asks, preeminently, can we connect with the past in some tangible way? This question will be central to the modernist poems we will review momentarily. Often, however, poets do not use the term, and we must look to the subtext of their work for evidence of their origin-seeking. We shall see this, for instance, in the case of Zukofsky"s "A" later in this chapter. Nevertheless, I contend that the search for origins is a ubiquitous endeavor, cutting across a number of writers and literary movements over the course of the last century.

With its preoccupation with origins, we can see the long poem as an inheritor of past English epic-inspired poems. ${ }^{9}$ Perhaps the primary difference between the ambitious texts of the twentieth-century and those that came before them, however, is the influence of new archeological discoveries in the latter half of the nineteenth- and beginning of the twentieth-centuries. ${ }^{10}$ These advances transformed poets' perceptions of the past by exhuming originary sites and cultures. ${ }^{11}$ However, poems do not need to directly state a preoccupation with archeological findings to be informed by originary thinking.

\footnotetext{
${ }^{9}$ We can observe origin-seeking in Middle English poems such as Sir Gawain and the Green Knight (ca. 1375-1400) and Layamon's Brut (ca. 1205) which both follow Geoffrey of Monmouth's The History of the Kings of Britain (ca. 1136) in positing the origin of England in the figure of Brutus, great-grandson of Aeneas. In the tradition of the English "epic," we can trace a line from Edmund Spencer's Fairie Queene (1596) to John Milton's Paradise Lost (1667) to Alfred Lord Tennyson's Idylls of the King (1859) which represents an inquiry into the past to divine the origin of the present. This is a tradition that the modernists inherit.

${ }^{10}$ Heinrich Schliemann's uncovering of Troy in the 1880s, the discovery of the Neolithic cave paintings in Altamira, Spain (1879) and Lascaux, France (1940), and the excavation of the Anglo-Saxon burial place Sutton Hoo in 1939 were all significant archeological events. Later in this chapter we will witness the way the discovery and excavation of the ancient Mesopotamian civilization of Sumer informed the thinking of a number of poets in the twentieth-century.

${ }^{11}$ The influence of the uncovering of originary places is clearly evident on Pablo Neruda in his discussion of the lost Incan city of Macchu Picchu in his Canto General (1950). Poets as diverse as W.H. Auden
} 
Indeed, we might cite Ezra Pound's early long poem (or sequence, depending on how one wants to read it) "Hugh Selwyn Mauberley" (1920) as a representative example of originary thinking in modernism. This poem looks into the devastating effects the first World War had on the modern psyche. "Mauberley’s" speaker famously comments, "[t]he age demanded an image / Of its accelerated grimace, / Something for a modern stage, / Not, at any rate, an Attic grace" (Personae 186). Here Pound contrasts his current cultural moment with the grandeur of the "Attic grace." The "grimace" of the modern age pales in comparison with the glories of the classical age. A return to the attitudes or approaches to living characteristic of that earlier era would presumably remedy the problems of the present; there could be a movement away from the "disillusions as never told in the old days, / hysterias, trench confessions, / laughter out of dead bellies" of contemporary existence (188).

In Pound's poem we recognize a desire to connect with the past that runs throughout modernism. John B. Vickery speaks of the "elegiac" mood of modernism, one which calls attention to that which has been lost over time. ${ }^{12}$ Writers like Pound are engaged in identifying and reevaluating historical moments from which current social practices either originated or deviated -- they are seeking "origins" in other words. Usually writers endeavor to adopt worldviews or to appropriate elements of culture (such as "Attic grace") which they perceive belonging to earlier periods. The crucial term here

("Archeology") and William Bronk ("After Tikal") have extolled archeology's virtues. Seamus Heaney's work also has been deeply informed by notions of excavation. A writer we will mention later, Peter Riley, actually uses turn-of-the-century archeological records as source material for the development of his long poem, Distant Points (1995). The list could go on.

${ }_{12}$ Vickery writes, "Modernist literature has a deserved reputation for being radically experimental in theme, structure, and technique. And yet the more one ponders it and its successors in the century, the more its collective voice appears to speak elegiacally" (51). He notes that this "elegiac" perspective requires modernist works to present a "backward look at cultural history perceived as a sequence of receding vistas and superimpositional perspectives" (54). 
is "perceive." Put simply, in this dissertation I am less concerned with critiquing whether or not these poets are accurately depicting past cultures than I am in adequately representing their responses to their perceptions. If Pound is convinced that he lives in a "botched civilization," an "old bitch gone in the teeth," his poetry must be viewed as an attempt to engage the past to offer solutions for present-day problems (188). However right or wrong he appears in his assumptions from our historical perspective is a separate matter.

When we consider originary thinking's role in modernism, T.S. Eliot is again paradigmatic. His account of the "auditory imagination" contains a metaphor which proves a shorthand designation for the modernist search for origins. He explains: What I call the "auditory imagination" is the feeling for syllable and rhythm, penetrating far below the conscious levels of thought and feeling, invigorating every word; sinking to the most primitive and forgotten, returning to the origin and bringing something back, seeking the beginning and the end. It works through meanings, certainly, or not without meanings in the ordinary sense, and fuses the old and obliterated and the trite, the current, and the new and surprising, the most ancient and the most civilized mentality. (The Uses of Poetry 111, emphasis added) Identifying the "origin" is clearly central to Eliot's conception of the poet's task. We will recognize this longing to "return to the origin and bring something back" in a number of long poems later in this chapter. Paul de Man writes that the "quest for the experience of origination is lived with all the intensity of a truly spiritual aspiration" and a sense of that "spiritual aspiration" pervades Eliot's desire to tap into the origin (97). 
The long poem is well suited to this endeavor since, as we have point out, it lacks strict genre conventions and offers poets ample space with which they can think about origins.

Eliot's statement also hints at the primitivist strain that runs throughout modernist conceptions of art and society. Primitivism in the long poem could be the topic of its own study, so I will not delve into the issue here except to say a few words. In the same set of lectures from which the quote above derives, Eliot argues that "[p]oetry begins [...] with a savage beating a drum in a jungle, and it retains that essential of percussion and rhythm; hyperbolically one might say that the poet is older than other human beings" (148, Eliot's emphasis). ${ }^{13}$ Marianna Torgovnick's work on primitivism is particularly useful here. She notes that "primitive always implied 'original,' 'pure', 'simple"' (19). She argues, "[t]he West seems to need the primitive as a precondition and a supplement to its sense of self: it always creates heightened versions of the primitive as nightmare or pleasant dream" (246). Like Edward W. Said's argument for Western views of "the Orient" which we will look at briefly in chapter three, Torgovnick examines the way Westerners project identities onto peoples of other parts of the world. This is clearly the case in Eliot's description of the "savage." Torgovnick links concern with the primitive to a preoccupation with "beginnings" that we have we called a search for origins: "[o]ur interest in the primitive meshes thoroughly, in ways we have only begun to understand, with our passion for clearly marked and definable beginnings and endings that will make what comes between them coherent narrations" (145). If Eliot is producing a "narrative" about poetry, then it is one which must account for the "savage" in the "jungle," one

\footnotetext{
${ }^{13}$ Marc Manganaro writes on Eliot, '[w]hat fuses the 'ancient' to the 'civilised' in the poet is the very process of formulating the sound of verse, of building up 'syllable and rhythm.' That process, inherently mystical or prelogical, Eliot saw as a return to 'primitive' origins" (402).
} 
which must go back to the origin to retrieve that which has been left behind - some missing "essential," to use his term.

The issue of primitivism in poetry returns in the work of Jerome Rothenberg later in the century. Rothenberg remains one of the groundbreakers in thinking about origins and modern poetry and he has spent a career editing one anthology after another, each examining alternative poetic traditions. These alternative traditions are typically comprised of poetry belonging to what Eliot called the "savage." For Rothenberg, however, "Primitive means Complex" (xix), as he explains in Technicians of the Sacred (1968), a text which includes poems from Africa, Asia, and Oceania. We thus witness a problematizing of the Eliotic model of "a savage [poet] beating a drum in a jungle." Rothenberg is careful to point out the culture-specific nature of views of what is "primitive": "[m] easure everything by the Titan rocket $\&$ the transistor radio, \& the world is full of primitive peoples," he writes, "[b]ut once change the unit of value to the poem or the dance-event or the dream (all clearly artifactual situations) \& it becomes apparent what all those people have been doing all those years with all that time on their hands" (xix). Technicians of the Sacred begins with a section entitled "Origins and Namings" $" 14$ and includes a selection of creation stories from a diversity of traditions. These texts attest to the recurring human commitment to establishing origins and poetry's function as the reservoir for this kind of thinking. Rothenberg's project continues in many ensuing volumes, including Shaking the Pumpkin (1972) which focuses on Native American poetry.

\footnotetext{
${ }^{14}$ We will see a later manifestation of the linking of origins and naming in chapter three's discussion of Walcott's Omeros.
} 
Rothenberg's engagement with originary thinking even persists into the recent anthology he edits with Pierre Joris, Poems for the Millennium (1995). The first book of this two volume set ends with a section entitled "A Book of Origins." ${ }^{15}$ As much a mission statement as a critical commentary, Rothenberg and Joris write about their Book of Origins,

It is impossible $[\ldots]$ to present the work of such a radical or innovative modernism without mapping at the same time some features of the old worlds, brought newly into the present $\&$ viewed there as if for the first time, to help to show us where we are. In this way the new seeks the old, as in many ways the old has often sought the new. (733)

Pound's conviction that "[a]ll ages are contemporaneous in the mind" serves as an epigraph for this section of the book. Coupled with Rothenberg and Joris' belief that "the new seeks the old" and "in many ways the old has often sought the new," Pound's epigraph offers an indication of how the idea of the origin is being presented in the chapter: as a source or historically distant moment which nevertheless is brought into the present by virtue of the mind's ability to hold disparate historical moments simultaneously. Originary thinking operates in this way in some of the poems we will look into in this dissertation. Many texts attempt to tap into more than one originary moment at a time. David Jones' The Anathemata (1952), for instance, mixes Welsh and Anglo-Saxon sources. For Jones, as much as Pound, "[a]1l ages are contemporaneous in the mind."

\footnotetext{
${ }^{15}$ As with his earlier anthologies of the 60's and 70's, in Poems for the Millennium Rothenberg favors avant-garde writers and presents the work of two poets we will be looking in this chapter: Charles Olson and Armand Schwerner.
} 
Given the shrinking influence of poetry in twentieth-century public life ${ }^{16}$ it seems little wonder that modernist poets like Eliot and Pound would turn to past cultures in which they believed poetic writing thrived and seemed to form a more integral part of the fabric of social discourse. Postmodernist writers have taken up the modernist inquiry into origins, although the postmodernists often seriously question or substantively alter the search for origins in modernist poetry, as Rothenberg illustrates with his complication of the concept of "primitive." I want to argue, then, that although one finds a preoccupation with origins among both modernist and postmodernist poets, these two groups look at the issue from strikingly different points of view. Modernists like Eliot wish to return to the past to modify and improve the present; ${ }^{17}$ postmodernists adopt a variety of positions, from looking for alternative origin points, as Rothenberg represents and as we shall see in Judy Grahn in chapter two, to questioning the cultural associations of origins as we shall observe Derek Walcott doing in chapter three, to the outright repudiation of originseeking as Geoffrey Hill demonstrates in chapter four. Before looking into specific long poems, however, let us pause for a moment and examine how origins have been depicted in contemporary critical thought.

\section{Poetics of the Origin}

To chronicle originary thinking's presence in critical theory, I want to begin by considering a short excerpt from "The Origin of the Work of Art" by Martin Heidegger. While Heidegger is here concerned with the origin of the individual work, rather than

\footnotetext{
${ }^{16}$ See the first chapter in Vernon Shetley's After the Death of Poetry for an account of the distance that has grown between poetry and the culture at large as a result of the "difficulty" of modernism.

${ }^{17}$ As we shall see in chapter two, Eliot's notion of the "mythical method" was a corrective measure meant as "a way of controlling, of ordering, or giving shape and a significance to the immense panorama of futility and anarchy which is contemporary history" (Selected Prose 177).
} 
more general historical origins like the poststructuralist thinkers I will be reviewing in a moment, his general attitude to the notion of the origin illustrates the way origins tend to be viewed in modernism, as we saw in Eliot's commentary on the auditory imagination. Heidegger begins his essay by noting that

Origin here means that from and by which something is what it is and as it is. What something is, as it is, we call its essence or nature. The origin of something is the source of its nature. The question concerning the origin of the work of art asks about the source of its nature. (17)

Heidegger's sense is that the origin of "something" can be assumed to illuminate it in some "essential" manner. This parallels the basic modernist paradigm of the origin. Why does Pound open The Cantos by alluding to Homer? Presumably because he wishes to appropriate the power he imagines epic verse having at its source. If Pound wants to render a modern version of the epic, one way he can hope to do so is to identify the "source of its nature." Put another way, he can produce a poem which reflects the "nature" of the epic poem by going back to its "source." We observe this process in other canonical long poems, such as those Bernstein analyzes in The Tale of the Tribe: Williams' $\underline{\text { Paterson }}$ and Olson's late-modernist Maximus Poems (1983). These poems similarly contend that the origin of the epic contains its nature and they thus make repeated allusions to the sources of the epic tradition.

Clearly, Heidegger's emphasis on the "essence" of things would fail to satisfy more recent views on the origin. Edward W. Said, for instance, accentuates the difference between the "beginning" and the "origin." He stresses the disparity between "the notion of beginning as opposed to origin, the latter divine, mythical and privileged, 
the former secular, humanly produced, and ceaselessly re-examined" (xii-xiii). While we might quibble with Said's claim that origin is not "ceaselessly re-examined" like the "beginning" might be, for the moment it is enough to note the dramatically different way the notion of the origin is represented in the short excerpts from Heidegger and Said. In Said's view the origin is no longer the measure of the "essence" of a thing. Instead it is a "mythical" and "privileged" concept which Said implies is not subject to the analytical scrutiny it should be. Between the two thinkers we can detect a distinctive shift in the way the origin is perceived, from an "essential" primacy in Heidegger to something of which Said believes we should be deeply skeptical.

This movement away from a privileging of the notion of the origin is represented elsewhere in speculative thought, perhaps most notably in Jacques Derrida's $\underline{\text { Of }}$ Grammatology. Here Derrida famously "deconstructs" origins through the course of his analysis of the phenomena of writing. Derrida speaks of the age-old valuation of speech over writing - "phonocentricism" over "logocentrism" in his words. By examining the texts of Jean-Jacques Rousseau and Claude Levi-Strauss, Derrida attempts to illustrate how speech has been assumed to be representative of "presence" whereas writing has been viewed as dubious "absence." Derrida asks, "[w]here does writing begin? When does writing begin?" and notes this is "a question of origin" (46). But he decides "there is no origin, that is to say simple origin" (46). He continues,

the questions of origin carry with them a metaphysics of presence. Without venturing here up to that perilous necessity continuing to ask questions of origin, we must recognize its two levels. "Where" and "when" may open empirical questions: what, within history and within 
the world, are the places and the determined moments of the first phenomena of writing? These questions must be answered by the investigation and research of facts, that is, history in the colloquial sense, what has hitherto been practiced by nearly all archeologists, epigraphists, and prehistorians who have interrogated the world's scripts. (46-47)

Derrida uses the notion of origins to interrogate the implications of thinking about writing. But the origin is never stable. Utilizing a term we saw in Heidegger -"essence"-- Derrida points out, "the question of origin is at first confused with the question of essence" (47). He concludes that "[o]ne must know what writing is in order to ask - knowing what one is talking about and what the question is - where and when writing begins" (47). But of course it is never possible to define the "origin" of writing and Derrida thus questions the possibility that the origin can thus hold the "essence" of something - here, writing specifically. He speaks slightly later in the text of "the myth of the origin," which echoes his basic belief in the artificiality of any origin (52). Through this line of inquiry, Derrida feels he is able to disable the binary oppositions that he believes have contributed to metaphysical thinking in Western philosophy (origins carrying a "metaphysics of presence" in his words).

We find a later appraisal of the concept of the origin in Judith Butler's work. Operating with the categories of heterosexuality and homosexuality in her article "Gender Insubordination," Butler concludes that if heterosexuality is taken to be the origin from which homosexuality is believed to be a copy, then heterosexuality can only gain its status as origin from its copy. In this way the copy seems to take precedence and dictates the existence of the origin. Butler puts it thus: 
The origin requires its derivations in order to affirm itself as an origin, for origins only make sense to the extent that they are differentiated from that which they produce as derivatives. Hence, if it were not for the notion of the homosexual as copy, there would be no construct of heterosexuality as origin. Heterosexuality here presupposed homosexuality. And if the homosexual as copy precedes the heterosexual as origin, then it seems only fair to concede that the copy comes before the origin, and that homosexuality is thus the origin, and heterosexuality the copy.

But simple inversions are not really possible. For it is only as a copy that homosexuality can be argued to precede heterosexuality as the origin. In other words, the entire framework of copy and origin proves radically unstable as each position inverts into the other and confounds the possibility of any stable way to locate the temporal or logical priority of either term. (723)

Butler's reading of the origin and the copy illustrates the arbitrariness of meaning in the very concepts themselves and represents, in a patently poststructuralist way, the manner in which binary oppositions are ultimately "radically unstable." The lesson we learn from her insight is that the origin and the copy are not concepts we can accept on their own merits; they are always in the process, like all binary oppositions, of deconstructing themselves. At this point, we have moved quite a distance from Heidegger's emphasis on the "essence" or "nature" of things which he argues the origin reveals. 
It is precisely this complication of the concept of the origin which allows us to draw some parallels between poetry of the last century and critical theory. Peter Baker has already begun the process of linking the long poem with developments in twentiethcentury speculative thought in his book Obdurate Brilliance. I would echo his findings here in a more specific way. Baker is generally engaged in showing how the evolution of the long poem has paralleled the movement from phenomenology to post-structuralism in philosophy. ${ }^{18}$ We can see how postmodern poems, like the ones I will be surveying here and providing more detailed discussion of in my case-study chapters, reflect the theorists' belief in the instability of the signifying system and similarly seek to disrupt traditional ways of thinking about origins. Like Derrida and Butler, postmodern writers are not willing to take the sovereignty of the origin at face value.

Even though it is relatively rare to see poets themselves use the term "origin" or explicitly express the desire to connect with or uncover origins (Heaney is an anomaly in this regard), we should not be prevented from seeking to place their work in the wider movement which represents "originary" thinking. I would thus like to distinguish the influence of three historical periods -- what I will call "originary moments" -- on the twentieth-century long poem. I will address each of these periods by first surveying them in this chapter and then giving them specific treatment in the chapters to follow. These three periods, which I will call "the Sumerian," "the Homeric," and "the Anglo-Saxon," I choose because they strike me as the most ubiquitous in recent poetry. The term "Sumerian" refers to poems which take ancient Sumer and its neighboring cultures, such as that of the Hittites, as an originary moment. "Homeric" refers directly to the two

\footnotetext{
${ }^{18}$ Baker writes, "[w] hat my model [of the long poem] is designed to uncover is that the view of language and subjectivity in modern theory - from, say, Nietzsche to Derrida - is similar to that worked out in the experimental long poems of the twentieth-century, beyond any question of influence" (2).
} 
touchstone poems attributed to the classical poet, The Odyssey and The Iliad. "AngloSaxon" refers to poems which take the pre-Conquest period in England as the focus for their engagement with the past. I should note that in the surveys of these three originary moments to follow I only wish to be suggestive; I hope to give a flavor of some of the more important poems in each category without being exhaustive.

Of course there are other directions in which my research could have gone. A concentration on the Paleolithic era characterizes poems like Clayton Eshleman's Placements series (1970's) and Nathaniel Mackey's Song of the Andoumboulou (1994). Peter Riley's Distant Points (1995) examines pre-historic England, particularly the earthen mounds built in prehistory which dot the British landscape. On the other hand, poems which look back to the Renaissance are common in twentieth-century poetry and it could be construed as another originary moment. Among postmodern poems, Kenneth Koch's Seasons on Earth (1987), with its heavy debt to Ariosto, James Merrill's Dantean The Changing Light at Sandover (1982), and Armand Schwerner's Cantos from Dante's Inferno (2000) all fit into this category. Beyond these texts, one could surely continue to search for works which engage origins in twentieth-century poetry. The task is virtually endless.

The retreat into originary moments has been handled by poets in varying ways, of course, but we can detect a general shift from earnest adoption of origins among modernist poets like Pound and David Jones to a more guarded, skeptical view advanced in writers like Schwerner or Geoffrey Hill. In fact the point I wish to stress -- that while the search for origins has often been re-envisioned by postmodern poets, it is nevertheless present -- has implications for our understanding of postmodern literature. It points to 
both continuity and discontinuity between modernist and postmodernist texts. On the one hand modernist and postmodernist literatures respond differently: modernism with a greater emphasis on searching for and relatively unwary appropriation of origins, postmodernism skeptical of or downright rejecting modernist practices. On the other hand, both are engaging the same problem: the twentieth-century's relationship with the past. I will consider the implications which recognizing similarity and difference among modernism and postmodernism has for our understanding of the last century's poetics in chapter five.

\section{The Sumerian}

Standing at the dawn of Western civilization, the literature and culture of ancient Mesopotamia, especially Sumer, has been an influence on the twentieth-century long poem. This can be seen as a product of our recent acquisition of knowledge of Sumer: prior to the nineteenth-century its existence was unknown and many of its important texts -- most notably The Epic of Gilgamesh -- only received wider currency in the last century. In fact, translations of Sumer's texts have proliferated over the past few decades, with one notable version of Gilgamesh coming from novelist and critic John Gardner (1984). Gardner was even able to incorporate Sumerian elements into his novel The

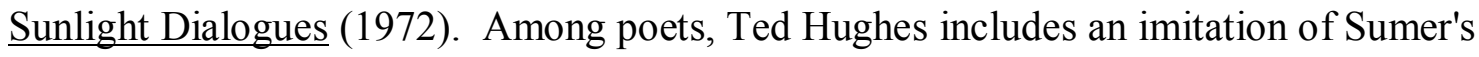
cuneiform stone tablets in Crow (1971), his sequence based on alternative creation myths. Hughes' poem is instructive because it offers us a sense of how Sumer has been viewed: as a civilization at the beginning of recorded time and history, fundamental even if we had not identified its importance as an originary moment earlier. The title of a book by 
the well known Sumerologist Samuel Noah Kramer sums up the popular notion well: "History begins at Sumer."

Sumer's influence on the long poem is especially strong in the second wave of modernists, particularly in the work of Louis Zukofsky and Charles Olson. Written over an almost fifty year span and divided into twenty-four parts of varying length, Zukofsky's "A" (1978) remains one of the touchstone texts of late-modernist literature. Most relevant for our purposes is A-23 which is composed of a section that translates The Epic of Gilgamesh. True to Zukofsky's sometimes recondite verse style, however, it is very difficult to follow the narrative thread of this rendering of the story. Zukofsky's poem is filled with word play ("Praise! gill..gam..mesh.." [540]) and the poet even changes the name of the lead character to "Strongest" and his companion Enkidu to "One Kid." In Louis Zukofsky and the Poetry of Knowledge, Mark Scroggins argues that "for the most part the reader is hard-pressed to find the principle of continuity in [the] baffling but sonically exquisite lines [of A-23]" (39). A short excerpt from Zukofsky's text, where Gilamesh and Enkidu are united, might offer confirmation of Scroggins' insight:

The Strongest threw him: their

friendship sealed. Strongest to Stronger:

"my heart weighs my lot, if $2 / 3$-god must die weal's beyond rancor; evil's unfinished I've seen myself corpse bloat, river flood-water surge my Wall-buoyed no more than any urbanite; 
hated I desire the forest --

risk to come thru it,

daring will reach my father

have him in unmeasured Distance["] (540-541)

The text seems a word-for-word translation, without much attempt at the kind of idiomatic rendering we are used to finding in translations produced for a wide readership. If there is some unity here it is probably in the use of sounds which are often alliterative and foreground Zukofsky's aesthetic vision.

Indeed, as with much of Zufosky's long poem, the key to understanding the poetics come in analogies to music, as when slightly later in the poem he writes, "by heart-strings 13 frets / propound a law of 'all' / and each fret tuned singly / salves fret or singularly frets / to salve thing to End / dissonance harmonized" (558). Zukofsky seeks to make "dissonance harmonized" in the verse that comprises A-23, from the staccato transliterated text that makes up the translation of Gilgamesh to the hints of Early Modern and mannered Elizabethan Englishes that fade in and out as the section reaches its conclusion. A-23 moves variously from one social register of English to another in such a way as to indicate that Zukofsky sees himself using the layers of linguistic forms as a metaphor for the passage of time and the stages of history. Or, as he says at the end of the section, calling again on a metaphor of music, "consonances / and dissonances only of degree, never- / Unfinished hairlike water of notes" (563). We can see, then, that the Gilgamesh text allows Zukofsky to draw an historical parallel between his own elliptical poetics and that of Sumer, thereby emphasizing the continuity of modern verse with that of antiquity. 
A fascination with ancient Sumer and its environs finds its way into the work of Charles Olson. Olson's long work The Maximus Poems (1983) is largely synthetic, as Pound's Cantos was before it, drawing together influences from cultures from all over the world. When Olson uses Gondwanaland, the image of the landmasses of Earth before their split, as the cover of the second volume of Maximus Poems, we are offered a visual representation of the kind of cultural juxtaposition he is engaged in producing in his poetry. Within Maximus one finds classical as well as pre-Greek civilizations depicted. Olson remarks that "the writing and acts which I find bear on the present [situation] are (I) from Homer back, not forward" (Collected Prose 207). The "forward" Olson speaks of here is subsequent history, especially the entrenched Humanism bolstered by the Enlightenment. Olson feels mid-century American culture has reached an impasse, especially with the encroachment of commercialism and commodified popular culture, and can be remedied only by a return to modes of thinking and living characteristic of earlier cultures. The Sumerian is one of these and throughout The Maximus Poems Sumerian motifs recur, from meditations on Sumerian history to allusions to Sumerian gods and goddesses. ${ }^{19}$ Olson's translation of the Hittite "Song of Ullikummi," although not a part of Maximus proper, has parallels in Maximus and reveals Olson's mission to represent different cultures within his poem.

As with Zukofsky, ancient poetics provide Olson with a parallel to the modernist strategies of narrative fragmentation and free verse poetics. A series of poems in the

\footnotetext{
${ }^{19}$ For Olson, Sumer was a source of human civilization, an alternative to the Greek classicism he resisted in his prose works. He tells Robert Creeley: "until we have completely cleaned ourselves of the biases of westernism, of greekism, until we have squared away at historical time in such a manner that we are able to see Sumer as a point from which all "races" (speaking of them culturally, not biologically) egressed, we do not have permission to weight the scale one way or another" (Selected Writings 97-98). For a critical commentary on Olson's use of Sumerian sources, see John Maier's chapter in the collection of essays he edits, Gilgamesh: A Reader.
} 
second volume of Maximus retells an Algonquin myth which is distinctly visceral in its imagery and language:

They said she went off fucking every Sunday.

Only she said she walked straight through the mountain, and who fucked her was the spirit of that mountain. (192)

The diction Olson employs in his reworking of Algonquin myth is echoed in his "Ullikummi." He notes his version of the "Song of Ullikummi" was "Translated from Hurrian and Hittite at / Wyoming (N.Y.) in March, 1964, and read / at Spoleto 1965 to honor the presence of / Mr. Ezra Pound." With language that recalls his Algonquin poems, Olson begins what Tom Clark calls a "free adaptation" (322):

fucked the Mountain

fucked her but good his mind sprang forward and with the rock he slept and into her let his manhood go five times he let it go ten times he let it go. (Collected Poems 600-601) The rest of the poem repeats these lines, sometimes mixed with transliterations of the original text. The repetition is apparently intended to mimetically reflect the action of the poem. It does not surprise us to find Olson repeat the image of the mountain after we saw it used in the Maximus retellings of the Algonquin story. As in Maximus, Olson 
employs an indecorous word choice to replicate a past poetics. ${ }^{20}$ Aside from matters of style, the language of "Ullikummi" gestures toward Olson's argument that the philosophers of Greece's Golden Age, particularly Aristotle, impede Western thought with "categorization" and "logic" - both of which prevent the kind of "action"-orientated existence he argues for the importance of and attempts to illustrate in "Ullikummi" (Selected Writings 55).

In contrast to Olson's attempt to return to a number of originary moments, whether they be pre-Greek, specifically Sumerian, or Algonquin, Armand Schwerner's The Tablets (1999) adopts a more skeptical point of view. In fact, The Tablets stands as a foil to Olson's Maximus Poems. Schwerner takes the work of Samuel Noah Kramer, who also was read by Olson, as the point from which the underlying methods of, and motivations behind, scholarship could be critiqued. Through a series of faux translations of cuneiform tablets, Schwerner represents -- albeit in a heightened way -- some of the problems of scholarship and its attempt to engage past cultures. Schwerner's poem is thus largely concerned with the problems of knowing and understanding the past. Perhaps Schwerner pushes the typographical limits of the lacunae-filled tablet genre furthest in "Tablet X." This poem is composed of a field of crosses, periods, and circles representing "missing," "untranslatable," and "confusing" parts of the "original" tablet, respectively. The scholar / translator's interpolation "[the the]" stands as the only words of the poem (35). This is an expose of modern scholarship's desire to wrest meaning out

\footnotetext{
${ }^{20}$ The term "fuck" is of course the most striking linguistic choice in the poem. Presumably it evokes for Olson the early Anglo-Saxon stratum of the English language and is thus ancient in itself, but as the OED indicates, its source is unknown. This kind of imagery is common to "primitivist" poetry, as revealed, for instance, by the excerpts from the Australian Aborigine "Goulburn Island Cycle" reprinted in Rothenberg's Poems for the Millennium: "Ejaculating into their vaginas - young girls of the western tribes. / Ejaculating semen, into the young Burara girls... / Those Ghoulburn Island men, with their long penes," etc. (744). This overt sexuality will be parodied in Schwerner's Tablets.
} 
of the rubble of the past -- in Schwerner's poem this "meaning" ("the the") is entirely invented by the scholar / translator.

A breakdown in the search for the origin occurs in the scholar/translator's note for Tablet VIII:

The reader who has followed the course of these Tablets to this point may find, upon looking back to Tablet I particularly, that I have been responsible for occasional jocose invention rather than strict archaeological findings. I now regret my earlier flippancy - an attitude characteristics of beginnings, a manifestation of the resistances a man often senses when he faces the probability of a terrific demand upon his life energy. Looking back myself to that first terrific meeting with these ancient poems, I can still sense the desire to keep them to myself all the while I was straining to produce these translations - desperately pushing to make available what I so wanted to keep secret and inviolable. (31) The level of self-consciousness and self-reflexivity illustrated here is absent in the examples from Zukofsky and Olson we have examined. Nowhere do those earlier writers critique their own searches for cultural or poetic origins in ancient Sumer and its environs as Schwerner makes his scholar / translator do here. The terms of the speaker's confession -- "desire," "straining," "desperately," "secret" -- all hint at the drive we observe in Zukofsky and Olson to touch history in some way, if only through their own projections onto past literature. While Schwerner clearly sympathizes with the projects of figures like Olson and Zukofsky, he must reject their approach and does so through the often comical interpolations of his scholar / translator. 
The work of Judy Grahn, whose long poem The Queen of Wands (1982) and its companion play The Queen of Swords (1987) will form the basis of my case-study chapter on this category, holds affinities with Schwerner's insofar as she also seeks to question the assumptions of modernism. Instead of parodying scholarly conventions, however, Grahn views Sumer and its culture as an historical moment prior to the advent of the patriarchal tradition which marks Western culture. Grahn's concern, in other words, is with Sumer as a cultural origin, and despite otherwise irreconcilable differences with Olson (namely his patriarchal persona), she agrees that a return to a state of mind which she detects in ancient Sumer can undo some of the historical injustices which are part of our cultural inheritance. An emphasis on Grahn's self-conscious fabrication of an origin based in Sumerian culture will form the focus of chapter two.

\section{The Homeric}

Since antiquity, Homer's epic poems The Odyssey and The Iliad have been touchstone texts in Western literature; the importance of the classical epic to Western notions of poetry and narrative is almost immeasurable. Among the literature of the twentieth-century we find a number of long poems which use Homeric themes or poetics as major motifs or generative devices. Ezra Pound's $\underline{\text { Cantos, }}$ for instance, opens auspiciously by evoking a crucial moment from The Odyssey. Pound's first canto is unique, however, because it is a translation of a sixteenth-century Latin version of Homer rendered by Andreas Divus. Through this approach, Pound signifies to us that language and time have intervened between him and his source (Homer) and he thus demonstrates the historical distance which separates the modernist poet from the origin. 
An engagement with Homeric poetics persists throughout modernist literature, not only among writers of the so-called "modern verse epic" like Pound, Williams, and Olson, but also in more lyric-driven writers like H.D. -- Pound's early fellow Imagist. Published after another notable long poem, Trilogy (1944-46), H.D.'s Helen of Egypt (1961) is an intriguing re-write of the story of The Iliad from Helen's point of view. Building on the tradition found in Stesichorus of Sicily that Helen was actually in Egypt during the events chronicled in The Iliad, H.D. produces a text which not only foregrounds the point of view of its female protagonist -- a notion clearly distinctive among modernist long poems -- but creates a work which will become important for many later female writers. As Lynn Keller contends in her survey of long poems by women, Forms of Expansion, H.D. should be viewed as a pioneer of the relatively recent tradition of female revision of the male-centered epic and long poem (16).

Helen in Egypt consists of a series of short dramatic monologues punctuated by the interpolations of an unidentified narrator. Early on the poem is centered on Helen as "Helena, Helen hated of all Greece" (2) who is descried as "the chosen, the flower / of all-time, of all-history" (20). Significantly, H.D. repeatedly describes Helen as text: "[Helen] herself is the writing" the poem says (22). This metaphor of textuality emphasizes the way women have been inscribed by male poetics throughout the ages. Even the narrator appears incredulous at times, remarking, "[i] $\underline{\mathrm{s} \text { this Helen actually that }}$ Helen? Achilles seems grudgingly to apologize for his first boorishness, 'I was afraid.' Who indeed would not be, at sudden encounter with the admitted first-cause 'of all-time, of all-history."' (47). Central to the poem is Helen's agency in a war which is claimed to be waged for her sake. Achilles bitterly notes, "she could leave by a secret gate, / and the 
armies be saved; //why does she hold us here?" (49). Thus Helen in Egypt can be read as an illustration of the manner in which a woman is made the subject of a conflict she is perceived to control but in fact is only subsumed by. In chapter two we will see that Judy Grahn uses H.D.'s poem as the starting point for producing her own story of women's history.

In more recent poetry, Louise Glück has used the narrative framework of The Odyssey as a means for exploring contemporary domestic life. In Meadowlands (1996), Glück places Homer's characters into archetypical familial roles. The poem is built by the interweaving of two narrative strands: a contemporary domestic crisis which leads to the isolation of its two protagonists and the Odyssey story itself which is similarly marked by domestic strain. "Nothing / is always the answer; the answer / depends on the story," the poem stresses (9). Indeed, as the story of Odysseus, Telemachus, and Penelope becomes conflated with that of two unnamed contemporary individuals in the poem, it is clear that Glück's poem works as a way to both bring The Odyssey into our time by focusing on current marital issues and to critique Homer's poem for its lack of interiority and sensitivity to gender-based concerns.

This critique is apparent in the poem when the Greek soldiers are on the beach outside the walls of Troy. The speaker declares, these are men of action, ready to leave insight to the women and children. Thinking things over in the hot sun, pleased by a new strength in their forearms, which seem 
more golden than they did at home, some

begin to miss their families a little,

to miss their wives, to want to see

if the war has aged them. And a few grow

slightly uneasy: what if war

is just a male version of dressing up,

a game devised to avoid

profound spiritual questions? (14)

The uneasy feelings which dawn on the men are presumably the "insights" which they had left earlier to the "women and children." The notion that war is potentially "a male version of dressing up" is obviously critical of the male-centered violence one finds especially in The Iliad, a poem whose initial lines announce its subject as Achilles' "rage" (77). In this way Glück is able to repudiate the male- and war- centered tradition of the epic, even as she appropriates elements of the ancient epic to examine issues of much interest to us today such as the dynamics of gender constructions.

Other recent work with Homer includes Christopher Logue's translation of The Iliad as War Music (1997). Logue's poem makes liberal use of anachronisms. ${ }^{21}$ These historical dislocations often update Homer's original epic similes. For instance, in an altered version of a famous scene from The Iliad in which Achilles addresses his horses, Logue describes the power of the horses pulling the chariot:

The chariot's basket dips. The whip

Fires in between the horses' ears.

And as in dreams, or at Cape Kennedy, they rise,

\footnotetext{
${ }^{21}$ We will look at anachronisms again in chapter four on Geoffrey Hill's Mercian Hymns (1971).
} 
Slowly it seems, their chests like royals, yet

Behind them in a double plume the sand curls up,

Is barely dented by their flying hooves,

And wheels that barely touch the world,

And the wind slams shut behind them. (214)

The simile of Cape Kennedy is strikingly anachronistic, yet it seems an appropriate image, a fitting contemporary analogue, for the wonder of a world in which a god can imbue an animal with the faculties of speech and limitless brute power. Logue's poem argues for the timelessness of Homer's text; that is, that it contains stories which speak to generations, indeed centuries, of humanity. His translation testifies to the belief that by reinvigorating Homer the original epic poems can be made even more relevant to our era.

This is not to say that Logue is concerned with simply rendering classical motifs in modern terms. In fact Logue's approach is sometimes unorthodox. Zeus' place within War Music as "God," in a monotheistic sense, proves one of the poem's innovations. We see this when Zeus is evoked by a parody of the Christian "Lord's Prayer" by Achilles: "Our Father, Who rules in Heaven, / Because Your will is done where will may be / Grant me this prayer [...]" (151). Through strategies such as this, Logue clearly wishes present-day readers to feel a great sympathy with the religious systems of the ancient Greeks. He strives to make them mirror us so we can better understand their range of reference and points to the continuity of human worship, even if this supplication clearly parodies Christian conventions.

Derek Walcott, winner of the Nobel Prize for Literature (1992), has also extensively reworked Homeric texts in his play The Odyssey (1993) and in his long poem 
Omeros (1990). Omeros will receive specific treatment in chapter three. Suffice it to say now that Walcott views the conflict in Homer's Iliad as analogous to the tensions that pervade his native Caribbean island of St. Lucia which was at the center of a long colonial struggle between England and France. Walcott's narrative re-casts Homer's characters while also producing figures of its own: its narrator becomes a major actor in the story, as does Homer himself as a transformed figure. In the chapter to follow I will look into the ways in which the intense self-reflexivity employed by Walcott qualifies his postcolonial reading of Homer as a literary origin.

\section{The Anglo-Saxon}

In twentieth-century poetics, Pound's 1911 translation of the Anglo-Saxon "lyric"

"The Seafarer" might be considered the starting point for Anglo-American literary interest in England's early historical period. Pound famously (and purposefully) mistranslates one line of the poem as "'mid the English" (it is usually rendered "among the angels") and in this way implies an argument for the importance of the "English" literary tradition. He notes that "The Seafarer" and Beowulf are examples of an "indigenous art," “an art not newly borrowed" he reports (Literary Essays 34). ${ }^{22}$ W.H. Auden follows Pound with a version of another Anglo-Saxon lyric, "The Wanderer," in 1930. Like Pound, who feels the latter half of "The Seafarer" is a later, Christian addition, Auden

\footnotetext{
${ }^{22}$ His complete statement runs thus: "[w]e may count the $\underline{\text { Seafarer, }}$, the Beowulf, and the remaining AngloSaxon fragments as indigenous art; at least, they dealt with a native subject, and by an art not newly borrowed. Whether alliterative meter owes anything to Latin hexameter is a question open to debate; we have no present means of tracing the debt" (34). As Hugh Kenner stresses, Pound's interests were consistent with his era: "[t]he time's enthusiasm for Anglo-Saxon studies was transmitted to Pound by Professor Ibbotson at Hamilton; it led in 1911 to his Seafarer" (108). John Tyrell points out that the genesis of Pound's long poem The Cantos also occurs in a conversation with his Anglo-Saxon Professor: "Ibbotson [...] introduced Pound to Anglo-Saxon. It was during one of their long talks that Pound conceived the idea of a long epic poem about history that would become The Cantos" (23).
} 
produces a rather truncated version of the medieval poem. ${ }^{23}$ These poets believe they are returning the texts to a more "original" state, free from the accumulations of later ages. Pound also notably applies an Old English-inspired alliterative verse style to the opening

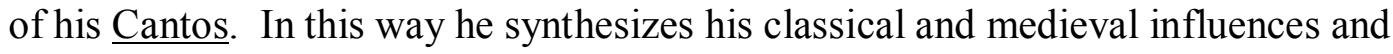
invites later poets to utilize "origins" to their own ends.

In other long poems, Anglo-Saxon themes and poetics make intriguing appearances. We have already noted that David Jones' The Anathemata: Fragments of An Attempted Writing (1952) integrates Anglo-Saxon and Welsh sources. Jones also reimagines other cultures of antiquity, such as the Roman Empire, in his poetry. Jones' strategy recalls Pound's mixture of diverse cultures. Anglo-Saxon culture takes precedence in The Anathemata, however, as Jones liberally peppers his work with Old English terms and employs a verse style which often gestures toward the medieval alliterative verse tradition. Occasionally Jones even introduces echoes of Anglo-Saxon texts into his poem, as when he writes, "for 'tis to garnish paps / that nourish such as must strike soundings in the gannet's bath." A note he supplies says, "[s]ee Anglo-Saxon Chronicle under A.D. 973, '... over the rolling waters, over the gannet's bath,...over the water's throng, over the whale's domain."' (146, Jones' ellipses). ${ }^{24}$ As with many other twentieth-century long poems, The Anathemata's author wishes to generate a sense of accumulated human culture and history through his methods of quotation and allusion; the long poem is the receptacle to hold these separate shards of the past together. Jones goes further than even Pound or Zukofsky in assuring we get his references by producing

\footnotetext{
${ }^{23}$ Nicholas Howe analyzes Auden's place in the host of writers who examine Anglo-Saxon origins in his article "Praise and Lament: The Afterlife of Old English Poetry in Auden, Hill, and Gunn." We should also note that a recent short article by Nick Salvato in Notes and Queries traces Zukofsky's debt to Old English sources for the section of "A" we have already associated with Sumerian poetics, A-23.

${ }^{24}$ Perhaps it is also a reference to "The Seafarer" in which gannets appear in line 20.
} 
a Preface that delineates his methods and footnotes that catalogue his sources, as the example illustrates. His approach contrasts with Armand Schwerner's skepticism about scholarly methods; in fact Schwerner's poem might be read as a parody of the conventions utilized in texts like Jones'.

Basil Bunting's verse style, especially as it appears in his long poem Briggflatts (1965), has been recognized as widely influential on later British poets. ${ }^{25}$ In Bunting's poem the passage of time is a major motif: "Then is Now," the poem says repeatedly. Bunting hopes to emphasize the present moment's continuity with the past and show how the two can occupy the mind at precisely the same time, as Pound argues in his phrase used by Rothenberg's anthology. Bunting evokes the figure of Eric Bloodaxe whom he stresses "Northumbrians should know [...] but seldom do, because all the school histories are written by or for southrons" (210). He suggests, "[p]iece his story together from the Anglo-Saxon Chronicle, the Orkneyinga Saga, and Heimskringla, as you fancy" (210). These historical allusions are developed concurrently with the life of the poem's protagonist who is characterized as "sick, self-maimed, self-hating, / obstinate, mating / beauty with squalor to beget lines still-born" (47). The poem is thus a kind of palimpsest in which the present of the protagonist is written over the past (Eric Bloodaxe and the Anglo-Saxon themes) which consistently remain visible in the text.

The music of Bunting's poem recalls Anglo-Saxon verse in its inversion of syntax and alliterativeness: "[w]ho sang, sea takes, / brawn brine, bone grit. / Keener than kittiwake. / Fells forget him. / Fathoms dull the dale, / gulfweed voices..." one stanza reads (48). Bunting's verse style performs a function similar to that we observed in the

\footnotetext{
${ }^{25}$ See the editors' introduction to Other: British and Irish Poetry Since 1970 for an assessment of Bunting's place in contemporary British poetry (xxviii).
} 
works of Olson and Zukofsky: the aesthetic effect recalls the cultures which are themselves the subjects of the poems. In other words, this is a kind of double approach to engaging or recalling an originary moment as the literary form (alliterative verse) is intended to signify the past culture (Anglo-Saxon). But as with Olson or Zukofsky, Bunting does not wish to slavishly employ a medieval verse form; instead he wants to transform the ancient poetics into a modern idiom so that the past is framed by the present.

The Irish Nobel Prize winner (1995) Seamus Heaney has consistently engaged the Anglo-Saxon past of Great Britain in his work. Heaney's view, however, is far more conflicted than Jones' or Bunting's. W.B. Yeats anticipated Heaney's ambivalence when he remarked "Gaelic is my national language, but it is not my mother tongue" (411). In a short poem from early in his career, "Belderg," Heaney similarly notes the tension that informs his use of language: "I'd told how its foundation // was mutable as sound / and how I could derive / a forked root from that ground / and make bawn an English fort, / a planter's walled-in mound, // or else find sanctuary / and think of it as Irish, / persistent if outworn" (Poems 169). The foundation is likened to sound and the importance of the English language is questioned in face of the Irish term "bawn." This poem comes from Heaney's volume North (1975) -- a book that contains part of his discontinuous series of "Bog poems" which constitute their own kind of long poem. In his reliance on language to imply political conflict - "bawn" and the "English fort" -- Heaney begins a process which reaches its latest phase in his translation of Beowulf (2000).

In North, Heaney writes of a wish to "come past / philology and kennings," but he finds himself back among those kennings when he begins a translation of Beowulf at the 
request of the editors of the Norton Anthology of English Literature (184). In describing his translation, Heaney employs a metaphor of excavation that appears often in North. He speaks of "a strong desire to get back to the first stratum of the language," that is, the writings of the Anglo-Saxons (Beowulf xxii). "I consider Beowulf to be part of my voice-right" Heaney declares, but he also recounts the cultural friction he experiences in approaching the first English epic as a Catholic-raised poet from Northern Ireland (xxiv). Language again turns out to be Heaney's means of critique and resistance. He speaks of his use of the word "bawn" in his translation as a way of placing his own linguistic politics into the poem. "Putting a bawn into Beowulf," Heaney writes, "seems one way for an Irish poet to come to terms with that complex history of conquest and colony, absorption and resistance, integrity and antagonism" (xxx). Heaney exhibits his consciousness of political history through the only means available to him as a poet: language.

Geoffrey Hill's work represents a more historically-conscious British poetry than that of Jones or Bunting. Hill's long poem Mercian Hymns (1971) and what I would consider its complementary poem, "An Apology for the Revival of Christian Architecture in England," comprise the case-study chapter on the Anglo-Saxon. Hill emerges as a poet who feels he must self-consciously engage England's history in a way it is difficult to discern among poets from earlier in the century. Like Heaney, Hill questions Britain's imperial past and ponders the significance of the events in Britain's turbulent history. Chapter four will thus focus on Hill's interrogation of notions of the nation as they are figured in originary thinking. 


\section{To the Case-Studies}

We have seen how a preoccupation with origins cuts across a number of writers over the course of the last century. We have noted that the search for origins which persists among modernist writers carries on into postmodernists but with constant alterations. The obvious advantage of examining poems concerned with origins is that it permits us to reflect on a collection of otherwise disparate poets, poets with agendas sometimes at odds with one another who nevertheless all engage in a consideration of the past's continuity with the present. In our conclusion we will consider what the implications are for our reading of modern and postmodern poetry, as well as issues such as nation and gender, in recognizing the enduring preoccupation with origins in the last century's long poems.

The poets have been chosen for each case-study chapter because of their diversity of identity (Grahn an American-born lesbian; Walcott a Caribbean writer of "mixed" ancestry ${ }^{26}$ Hill a canonical British poet). They also differ in their approaches to origins. Grahn seeks to evaluate and revise origins. Walcott questions the veracity of the European tradition which finds its origin in Homer. Hill examines the logic of seeing Anglo-Saxon England as the origin of the modern British nation. Their long poems were all published in the latter decades of the century and thus sit comfortably -- historically speaking -- within postmodernity (Hill's poems from the 70's; Grahn's from the 80's, and Walcott's from 1990). As we look into each I would like to keep in mind that even though these poems are quite different in local ways in their relationship to origins, they are united in their attempt to reassess the modernist search for origins. They are engaged

\footnotetext{
${ }^{26}$ The speaker of Walcott's "The Schooner Flight" shares his author's heritage and notes, "I have Dutch, nigger, and English in me, / and either I'm nobody, or I'm a nation" (Collected Poems 346).
} 
in a process of literary dialogue, in other words, which continues modernism's inquiry into the past. Let us now look closer at these poems. 


\section{Chapter Two}

\section{"A New Myth of Origins": Judy Grahn's A Chronicle of Queens and Popular Culture}

\section{Popular Culture and the Postmodernist Long Poem}

Postmodernism is often seen as a marriage of the high and the low, the intersection at which elite and popular culture meet and intermingle, if not wholly collapse into one another. A recent study by John Storey suggests popular culture is the "invention" of "intellectuals" as a means to widen the gap between social classes. ${ }^{1}$

Historically this is a division which coincides with the onset of literary modernism and it is against what Storey calls "modernism's cultural elitism" that postmodernism posits itself (64). ${ }^{2}$ Although postmodernism's embrace of popular culture has been a problem for critics like Terry Eagleton, who admits a "negative" view of the phenomenon (viii), ${ }^{3}$ postmodern writers are often liberated by the integration of elements of popular culture into their works. As Storey asserts, the use of popular culture motifs by postmodernists

\footnotetext{
${ }^{1}$ Storey writes, "[i]n the late eighteenth, throughout the nineteenth, and into the early part of the twentieth century, different groups of intellectuals [...] 'invented' the first concept of popular culture. In fact these debates eventually produced two definitions of popular culture. The first was popular culture as a quasimythical rural 'folk culture,' and the other -- and it was very much the 'other' -- was popular culture as the degraded 'mass culture' of the new urban-industrial working class" (1).

${ }^{2}$ Storey cites other theorists, such as Andreas Huyssen who writes, "[t]o a large extent, it is by the distance we have traveled from this 'great divide' between mass culture and modernism that we can measure our own cultural postmodernity" (57). In his use of the term "mass culture" Huyssen echoes Frankfurt School theorists like Theodor W. Adorno and Max Horkheimer who form part of the critique of his book.

${ }^{3}$ Eagleton, like Storey, relates the advent of postmodernism to historical circumstances and finds in it a combination of high and low culture that is the product of our economic system: "[postmodernism] springs from an historic shift in the West to a new form of capitalism - to the ephemeral, decentralized world of technology, consumerism and the culture industry, in which service, finance and information industries triumph over traditional manufacture, and classical politics yield ground to a diffuse range of 'identity politics.' Postmodernism is a style of culture which reflects something of this epochal change, in a depthless, decentered, ungrounded, self-reflexive, playful, derivative, eclectic, pluralistic art which blurs the boundaries between 'high' and 'popular' culture, as well as art and everyday experience" (The Illusions of Postmodernism vii).
} 
helps them critique the "cultural elitism" of, and question the assumptions underlying, modernism's dubiousness toward "low" culture.

The postmodern long poem has been particularly fertile ground for different forms of culture to take root. The monolithic "tale of the tribe" of modernism, to use Pound's phrase, has been tempered by a growing awareness among writers of the long poem's place in a culture which has little use for poetry (Guide to Kulchur 194).

Combining popular culture materials and motifs with the "high" culture form of the long poem permits postmodernists to bridge the perceived "Great Divide" between the high and low. We might cite a number of postmodern long poems in this regard. Kenneth Koch's ottava rima Seasons on Earth (1987), for example, uses Disney characters to complement his story of a Japanese baseball hero named Ko. Edward Dorn's Gunslinger (1975) is another outstanding example. This poem uses the conventions of 60's TV and movie Westerns at the same time it employs a largely satiric approach. Writers like Koch and Dorn indicate a shift has occurred in what could be viewed as source material in the long poem. ${ }^{4}$ John Ashbery's early long poems "Europe" (1962) and "The Skaters" (1966) similarly use popular culture sources. ${ }^{5}$ Popular music, film, and vaudeville make repeated appearances in John Berryman's The Dream Songs (1969). For these poets the popular is used subversively to critique modernist assumptions about the proper subject matter of poetry.

\footnotetext{
${ }^{4}$ Dorn says, "I consider one thing as good as another, whether it arises from science or the so-called humanities, the newspaper or a bubblegum wrapper. All that's equal to me, as source" (quoted in Beach 223).

${ }^{5}$ As David Lehman points out, the sources of these poems are popular children's literature; in the case of "Europe" it is an "Edwardian book for girls" called Beryl of the Biplane and in "The Skaters" the inspiration comes from a book called Three Hundred Things a Bright Boy Could Do published in 1911 $(160 ; 121-122)$.
} 
One finds popular culture in another poet of the period: Judy Grahn. As a lesbian activist, Grahn has consistently strived to use popular materials to represent the "common" woman, as the title of a volume of her poetry attests. ${ }^{6}$ Her work thus eschews the "difficulty" and "cultural elitism" of high modernism in favor of an idiom more accessible to the average reader. The reason for this approach is simple: Grahn seeks to alter our ways of thinking about the position women have occupied in society for millennia; through a poetry which repudiates the densely allusive and fragmented poetics of modernism she can more directly make her points and project herself as a woman rewriting history to "express herstoric narration," as she says (The Queen of Wands xi). In her A Chronicle of Queens project, Grahn's main strategy is to use archetypal and mythological female figures to offer a depiction of women antithetical to the subservient position they have until recently occupied (and perhaps still do). To date, two of the four promised installments of Grahn's Chronicles have appeared: The Queen of Wands (1982) a long poem centered on the recovery of a "Helen" figure from male-dominated history and The Queen of Swords (1987) a verse drama (although she speaks of it as a single poem $[\mathrm{x}])$ that recasts ancient Sumerian myth in a contemporary setting. Since Grahn's gender- and sexuality- based poetics in A Chronicle of Queens has been well analyzed by critics, ${ }^{7}$ my focus on the presence of popular culture motifs in this chapter

\footnotetext{
${ }^{6}$ In her collected poems from 1978 entitled The Work of a Common Woman, Grahn writes, "I wanted, in 1969 , to read something which described regular, everyday women without making us look either superhuman or pathetic" (60). In her introduction to the book, Adrienne Rich remarks, "[t]he "common woman' is in fact the embodiment of the extraordinary will-to-survive in millions of women, a life-force that transcends childbearing: an unquenchable chromosomatic reality" (18). See also Johanna Dehler's Fragments of Desire for a discussion of Grahn and the notion of the "common" woman (71-90).

${ }^{7}$ Critical attention of Grahn's examination of sexuality includes Sylvia B. Henneberg's study of The Queen of Wands. She notes that the figure of Helen at one point in the poem "assumes a lesbian identity which [...] can be traced throughout [...] all of The Queen of Wands." Henneberg decides that in Wands "Grahn $[\ldots]$ does away with compulsory heterosexuality and maternity."
} 
considers a quality of Grahn's work that has yet to receive comment. As in Dorn, Koch, and the others, I see the extended use of popular culture in A Chronicle as a means for Grahn to distinguish her project from modernist precursors, in the process rejecting their cultural elitism and male-centered worldviews.

\section{Myth in Judy Grahn}

Before moving on to discuss Grahn's long poem and play, we should pause for a moment and examine an element of her work we have already mentioned: its use of myth. Myth and popular culture meet in another notable long poem from the period, namely James Merrill's The Changing Light at Sandover (1982). Like Grahn, Merrill mixes high and low sources. Sandover is a vast (500+ pages) exposition of the relevance of spirituality in contemporary society. Helen Sword's comments on Merrill's (and Sylvia Plath's) use of a kitschy product of popular culture -- the Ouija Board -- as a divinatory device has some bearing on our examination of Grahn here:

[the Ouija's] very status as a commercial object $[\ldots]$ could well explain its tremendous symbolic appeal for two poets appropriate to a literary generation caught between modernism's mythopoetic nostalgia and postmodernism's self-conscious romance with commodity culture. For both Merrill and Plath, the Ouija board functions as a sort of psychic leveler, a fulcrum balancing the prophetic pretensions and iconoclastic impulses of high and low cultures, respectively. (556)

Sword usefully points out the conflation of the "mythopoetic" leanings of modernism and postmodernism's interest in "commodity culture" in Merrill. I want to suggest that, 
comparable to what Sword sees in Merrill, Grahn employs both myth and popular culture motifs to take stock of the culture in which she lives. Like Merrill, Grahn integrates popular culture into her poetry at the same time she evaluates the function of myth in modern-day society.

The "mythopoetic nostalgia" which Sword evokes and which Grahn and Merrill work against perhaps finds its defining moment in T.S. Eliot's advocacy of what he calls the "mythical method." In a 1923 review of James Joyce's Ulysses, Eliot writes:

In using myth, in manipulating a continuous parallel between contemporaneity and antiquity, Mr. Joyce is pursuing a method which others must pursue after him. [...] It is simply a way of controlling, of ordering, or giving shape and a significance to the immense panorama of futility and anarchy which is contemporary history. It is a method already adumbrated by Mr. Yeats [.... Psychology [...] ethnology, and The Golden Bough have concurred to make possible what was impossible even a few years ago. Instead of narrative method, we may now use the mythical method. It is, I seriously believe, a step toward making the modern world possible for art. (Selected Prose 177-78)

A preoccupation with myth figures largely in many canonical modernist works, especially in poems by W.B. Yeats, William Carlos Williams, and of course Eliot himself. It is noteworthy that myth appears a refuge in Eliot's thinking, helping one to escape the "futility" and "anarchy" of the present. ${ }^{8}$ Eliot draws our attention to the continuities of history, what he terms a "continuous parallel between contemporaniety

\footnotetext{
${ }^{8}$ We should recall the argument of John B. Vickery we reviewed in our introduction that modernism tends to speak "elegiacally," out of a sense of loss for that which has been left behind in the past.
} 
and antiquity" which myth offers. Ultimately, however, it is difficult to see how this "mythical method" makes the "modern world possible for art" except in accommodating the "mythopoetic nostalgia" that appears in the works of Eliot and others. 9

The OED defines myth as a "traditional story, typically involving supernatural beings or forces, which embodies and provides an explanation, aetiology, or justification for something such as the early history of a society, a religious belief or ritual, or a natural phenomenon." If the myth seeks to "explain" or "justify" "the early history of a society" we might say it works as a statement on origins, as a way to posit an origin or legitimize something being called an origin. The OED definition thus suggests a relationship between the concepts of myth and origins. Eliot's mythical method appears to be a means of rationalizing the employment of themes or motifs which find their source in antiquity and thus confer authority on his point of view. Contrary to this, Judy Grahn feels she can re-envision myth so that it questions the origins of patriarchy and asserts a woman-based culture in the distant past. In her prose work Blood, Bread, and

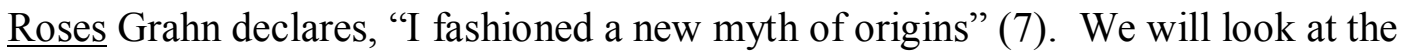
significance of this notion in The Queen of Wands shortly. For the moment we might observe that Grahn's work rests on the assumption that she can posit her own explanatory story (myth) of how a woman-exclusionary culture began (origin) which we must now work to usurp.

Grahn's impulse to rewrite conventional myths (particularly in The Queen of

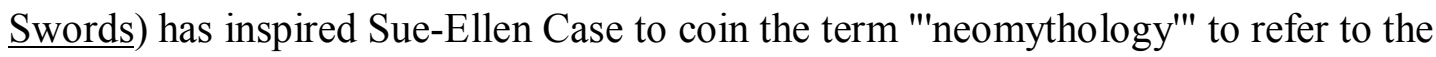

\footnotetext{
${ }^{9}$ Marc Manganaro argues that the use of myth in modernism descends from James Frazer's The Golden Bough (1890) and allows figures like Eliot to assume a "voice of authority." On Eliot's notion of the mythical method, Manganaro writes, "[t]he method, in the end, pays tribute to the genius of the arranger: 'making the modern world possible for art' becomes, in practice, the artist making the modern world in his own image" (79).
} 
project of "'taking back the myths"' which she sees operative in Grahn's work (51).

Neomyths retell old myths "from within a gynocentric tradition, tracing new histories

[...] which result in an alternative interpretation of their symbology and meaning" (51).

This work leads to a reinterpretation of history that evokes a matriarchally-based culture which fell with the rise of ancient Greece (51). ${ }^{10}$ Myths, like origins in Grahn's view, are unstable and arbitrary; they can be changed, or replaced. Contrary to Eliot's metaphor, which we cited in our introductory chapter, to "return to the origin and bring something back" in his statement on the "auditory imagination," Grahn feels she can, indeed must, construct the origin herself; myth and popular culture - images of the past and the present, respectively - become two tools to use in this endeavor. The constructed nature

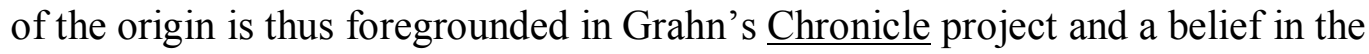
"essence" of the origin, as we saw in Heidegger's statement on origins in chapter one, is repudiated.

\section{The Queen of Wands: The Goddess and Popular Culture}

In many ways Grahn is very much of her time in that her work evokes a belief in a primary Goddess who was systematically replaced with the monotheistic male God of several of the world's major religions that survive today. The Goddess tradition received wide currency over the last century and a half. As Ronald Hutton has shown, archeological work of the late-nineteenth and early-twentieth -centuries exhumed, and sometimes fabricated, evidence for worldwide goddess worship which reportedly

\footnotetext{
${ }^{10}$ Johanna Dehler has examined the influence Sappho has exerted on Grahn's "mythmaking" and concludes that "both Sappho and Grahn construct a different philosophical paradigm based upon a new definition of desire, identity, beauty, and cultural origin" ("Lesbos Revisited” 205-206).
} 
predated the establishment of male-centered societies. ${ }^{11}$ The argument for an early goddess-based society gained popularity with many in the 1970's. One of its effects was to lead some to return to what they saw as originary religions, such as Paganism and Wicca, which elevated women to a status equal to, or eclipsing, that of men. Grahn's

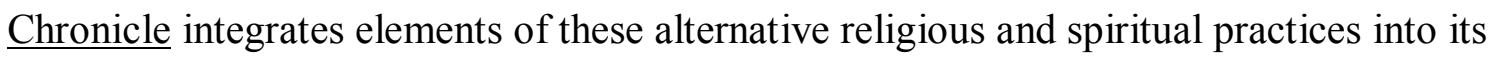

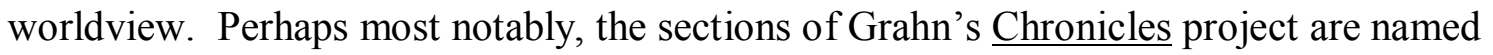
after the Minor Arcana of the Tarot deck and remind us of the many occult-inspired literary works of the last several decades. ${ }^{12}$ Occult themes will persist throughout The Queen of Wands.

Robert Graves' The White Goddess (1948) remains an important text that bridges Eliot's mythical method and Grahn's later "neomyths." One of the major modern statements on mysticism in poetry, Graves' book also advocates a goddess-centered literature. Grahn acknowledges the importance of The White Goddess in several places. ${ }^{13}$ Graves believes that reflection on an originary goddess can lead one to the source of "true poetry." ${ }^{14}$ He explains,

My thesis is that the language of poetic myth anciently current in the Mediterranean and Northern Europe was a magical language bound up with popular religious ceremonies in honour of the Moon-goddess, or

\footnotetext{
${ }^{11}$ See especially Hutton's discussion in chapter two of his book where he provides an historical overview of the attempts to "find" a Goddess and also pages 278-282 which detail later developments.

${ }^{12}$ One thinks of other occult-based texts in postmodernism. We have already noted the use of the Ouija board in James Merrill and Sylvia Plath. The Tarot figures in Thomas Pynchon's Gravity's Rainbow (1973) and Italo Calvino's The Castle of Crossed Destinies (1976). In Grahn's use of the Tarot there has been a movement beyond the forbidding vision of "Madame Sosostris" and her "wicked pack of cards" present in Eliot's "The Waste Land" (136). Instead the Tarot recognizes the female element in Grahn's cultural heritage and by using it as an overarching metaphor she is able to "divine" a more hopeful future. We will see magical imagery persist in The Queen of Wands.

${ }^{13}$ She mentions Graves' work in her foreword to Betty De Shong Meador's translation from Enheduanna (xiv) and in her own book Blood, Bread and Roses (xxii).

${ }^{14}$ Speculation exists that Graves' lover and fellow poet Laura Riding was the White Goddess, an idea she resented (See Deborah Baker 401-403).
} 
Muse, some of them from the Old Stone Age, and that this remains the language of true poetry -- "true" in the nostalgic modern sense of "the unimprovable original, not a synthetic substitute." (10)

A few pages later he concludes that his book is "about the rediscovery of the lost rudiments, and about the active principles of poetic magic that governs them" (17). His project, then, is one centered on recovering the origins of poetry in a culture coalesced around goddess worship. In Graves' view, a goddess-centered society is primary, an "unimprovable original," to which we must return. If Graves' book is about recovering lost knowledge it is also an effort, like Eliot's mythical method, to take "a step toward making the modern world possible for art" by reconnecting us with that which we have lost. If we ask what distinguishes Grahn's project from Graves', we must account for the position from which each speaks: Graves is perhaps located on the margins of modernism, but Grahn is certainly located well beyond those margins. The belief in the immutability of myth in Eliot persists in Graves, whereas Grahn recognizes the arbitrariness of myth.

Although Graves looks to pre-history for evidence of the Goddess, Grahn traces an initial woman-centered culture back to ancient Sumer. In her Foreword to Betty De Shong Meador's recent translation of the Sumerian poet Enheduanna, Grahn reveals her mission to recover a forgotten woman-based literature. As Grahn stresses, Enheduanna is presumed to be the first identifiable poet of writing in history (xii). In her own Chronicle of Queens, Grahn presents a synthesis of disparate mythological traditions to show the ways in which images of women have persisted over time and across cultures. As part of her evidence for the overlap of mythological traditions, she stresses the linguistic 
similarities in the names of a number of goddesses in the section "Helen's Names" in The Queen of Wands. "Helen" becomes a synecdoche for women's plight in Western history. The poem begins,

Helen has such a lengthy history

as a god and as a queen

that her name, El-Ana, has derivations

and echoes that are widespread over

continents. The Muhammedan Venus is called

Anael, which has the syllables of

El-Ana reversed. From El comes Bella

meaning "beauty."

Beluah Ann is one variation, as are Helena, Helga, Holga, Helda, Hilda, Holde, Hillary, Helna, Hidegard, Helle. Hlin. Hlinda, Linda. Honnele. Heleme. (16)

And her list goes on. ${ }^{15}$ It is significant that Grahn should mention "Hilda" as one of these names. It recalls Hilda Doolittle, better known as H.D., Grahn's acknowledged precursor and author of Helen in Egypt (1961) which we touched on briefly in our introductory chapter. H.D. is indeed something of a Helen figure for Grahn in that she represents a

\footnotetext{
${ }^{15}$ Popular literature from the period attests to the persistence of the Goddess through a constantly shifting collection of names. Merlin Stone, for instance, in When God Was a Woman (1976) writes, "it becomes clear that so many of the names used in diverse areas were simply various titles of the Great Goddess [...] We are not, however, confronting a confusing myriad of deities, but a variety of titles resulting from diverse languages and dialects, yet each referring to a most similar female divinity. Once gaining this broader and more overall view, it becomes evident that the female deity in the Near and Middle East was revered as Goddess - much as people today think of God" (22). The list of Helen's names in Grahn has been shown to be a strategy also of H.D. in her long poems (Montefiore 186).
} 
woman attempting to forge her own aesthetics even as she is dominated by a male-

centered modernism. ${ }^{16}$

In the preface to her long poem, Grahn notes that she "first met the Queen of Wands in a 1913 translation of a clay tablet of ancient Babylonian writing" (xii). Ancient Sumer is a watershed culture for Grahn because it provides the cuneiform tablet which supplies the inspiration for her poem and it serves as the origin for the divine female figure Grahn wishes to resurrect. Through this process Sumer becomes both an origin and an end in the sense that Grahn has to work her way back through time to reach it. "In investigating Helen's story I found an astonishingly worldwide myth of a female god of beauty, fire, love, light, thought, and weaving," Grahn writes, "[s]he is a figure of many forms and names and countries, and she is the Queen of Wands" (xii). We have already sampled one of the many lists of variant names of the Helen figure which Grahn incorporates in her works. She has little trouble embracing Carl Jung's belief in the persistence of archetypes, and indeed she makes reference to Jungian ideas in her work. ${ }^{17}$ The Jungian paradigm of recurring archetypes over the course of human history provides Grahn with a philosophical structure she can use to elaborate her own version of myth.

\footnotetext{
${ }^{16}$ The relationship between Grahn and H.D. has been developed by a number of critics. Jan Montefiore writes about H.D.'s relationship to later women writers. She concludes, "[i]n Judy Grahn's evocation of female 'godhead' represented by the divine weaver Helen, her reading and memories of H.D.'s poetry clearly help her, like [Adrienne] Rich and [Denise] Levertov, to find the numinous in the actual - but in a less sophisticated way" (186). Lynn Keller has examined the relationship of Grahn to H.D. and another important figure, Gertrude Stein, in lesbian poetics. Keller writes: "I propose in her bringing together of precedent strategies of Stein and H.D., Grahn approaches these forebears as a butch / femme couple" (67). She concludes that "the process undergone by Grahn's Helen is, in part, a movement from the archetypal femininity of H.D.'s Helen to a fem identity freed from the hobbles of patriarchally determined femininity" (68). In Keller's view, Grahn's Helen is finally successful in overcoming the obscurity forced on her by male authorities.

${ }^{17}$ The influence of Betty De Shong Meador, Jungian analyst and translator of Sumerian texts is acknowledged in Grahn's Foreword to Meador's book. In her work on poetics, The Highest Apple, Grahn calls for an "art based on our collective consciousness and collective unconsciousness" (87). We will see Jung's influence also evident in The Queen of Swords later in our discussion.
} 
To demonstrate the primacy of the Sumerian cultural moment, Grahn offers the 1913 translation, mentioned in her preface, of the "Tablet of Lamentation" rendered by Stephen Langdon. It clearly affords evidence of the historical oppression of women. "In my temple he pursued me, in my halls he terrified me," its speaker intones,

Like a frightened dove upon a beam I passed the night.

Like a sudin-bird that flees from a cranny I hastened my night.

From my temple like a bird he caused me to fly.

From my city like a bird he caused me to fly (9)

These lines work as historical evidence for Grahn's contention that women have been subjected to the dominance of men for millennia. She writes, "[m]oved by the tale told in the Tablet of Lamentation, I searched for other stories of stolen queens, wanting to identify this one with a name, occupation, some motive for the theft" (xii). As her poem goes on, she will tie this systematic subjugation of women to the story of Helen of Troy to offer a comprehensive argument for viewing the history of the West as one built on gender inequity. Grahn's duty is to disrupt this division so that women return to a central position of power in society and cease to concern themselves with threats of violence from men like the one who terrifies the speaker of the "Tablet of Lamentation."

Despite the originary nature of the Sumerian materials, Grahn chooses to name her archetypal female figure "Helen" because of the image it evokes of a women abducted by men who fight blindly and ruthlessly over her, all the while oblivious to her desires. As Grahn says, "[t]he most persistently retold story of a queen stolen in Western tradition is that recounted in The Iliad" (xii). The depiction of Helen in Homer's epic 
proves to be a defining moment in Grahn's "herstory." In her copious notes to The Queen of Wands she argues,

[i]n brilliant, world-influencing Egypt, the rulership passed through the female line and the economy was solidly in women's hands $[\ldots]$ men did much of the labor and craftwork while women did much of the management [...] The Trojan War represented a shift in power: the Greek soldiers who won took skilled labor, especially the valuable weavers, back with them as slaves. (104)

This historical shift -- from an ancient Egyptian culture in which Grahn sees women retaining agency to a civilization in which they are made subject to the economic interests of men -- is dramatized in the poem, notably in a soliloquy by Helen. Like H.D. before her, Grahn will offer us a view of history from Helen's perspective. Helen remarks:

I went out a Queen

a Sovereign, Mother of my people

and a lover --

I came back a captive.

My husband had gone out

a King, a Sovereign

and a soldier.

He came back a tyrant, a master of slaves -and I came back a slave. (25-26) 
The extent to which Helen speaks for herself, and possesses an interior life which she feels free to verbalize, distinguishes Grahn's character. The figure of H.D.'s Helen in Egypt does not display the same self-conviction that Grahn's does. ${ }^{18}$ The diction used by Grahn's Helen is particularly revealing: terms like "captive," "tyrant," and "slave" clearly come from the language of enslavement and colonization. Grahn references the West's long history of domination of other cultures in the notes accompanying the poem (107108). Her recognition of the theme of colonization in The Queen of Wands' allows her Helen to be more attuned to the postcolonial concerns of the final decades of the twentieth-century than H.D.'s figure who appears to still be trying to establish the individuation which Grahn's character is in the process of expressing. ${ }^{19}$ Grahn is able to build on H.D.'s work, in the process rendering a Helen who seems all the more "real" because of her contemporary point of view.

Yet the contemporary nature of Grahn's Helen has the potential to appear misguidedly anachronistic. Part of the purpose of Geoffrey Hill's depiction of the AngloSaxon King Offa in Mercian Hymns (1971), as we shall see in chapter four, is to explore the problems that come with bringing an historical person into the present for the purpose of identifying an originary moment in the past. In Mercian Hymns, Offa is placed into a contemporary situation almost intact; we will see how attempts to confer a modern interiority on him finally appear ridiculous in the poem. By contrast with Hill's cautionary tale, Grahn wishes to show the persistence of the Helen figure, a figure who is certainly less defined (because she cannot be based on an historical personage like Offa)

\footnotetext{
${ }^{18}$ Her speech is often filled with doubts and hesitations: "Helen says, 'I am awake, no trance, though I move as one in a dream.' But again she reassures herself. She had said of herself and Achilles in Egypt, 'we were not, we are not shadows' and she had insisted that 'the hosts surging beneath the Walls, (no more than I) are ghosts"” (43).

${ }^{19}$ We will look at postcolonial themes as they occur in Derek Walcott's Omeros in the next chapter.
} 
than Hill's character. We will see that Hill's Offa retains his kingly affectations when he enters the modern world, despite the disparity between his historically-distant England and the modern British nation he comes to occupy. Helen, however, acclimates herself to modern society, as we shall see. This is not to say that Grahn is pleased with all aspects of current popular culture; in fact we will note that she often registers ambivalence. However, the purpose of her poem is not to examine the problems that follow in attempting to uncover an origin in the past as in Hill's case. Rather, as we have seen, she seeks to show that the origin can be constructed to correspond with the political motivations of the individual. Origins are always arbitrary in Grahn's view.

Through the course of The Queen of Wands, Helen is represented in a number of guises, from a weaver, to the Norse Frigga, to Sleeping Beauty, to Helen of Tyre. These different appearances offer Grahn a way of representing Helen through the ages and across cultures. Helen's persistence over time is emphasized in the poem: "I am the Queen of Wands," she says, "I am who stands / who always will / and I am who remembers / the connections woven, little eggs / along the message line" (41). The "message line" here is presumably the literature that links Helen to Grahn, across centuries. Helen's importance is asserted to the point that she is made present at creation: "I remember giving dinosaurs / to the tall unfolded ferns to entertain them. / and [sic] immortality to the cockroach / I remember the birthday of the first / flower" (41-42). Within a few lines Helen appears to have succeeded in replacing the traditional monotheistic male god as originator of life on earth with her own image. This is a clear example of Grahn expressing the "herstoric narration" she announces in the preface to her poem. 
The element of popular culture I cited at the beginning of our discussion comes into view in Grahn's examination of Goddess imagery in contemporary society, in particular in film. Grahn explains her view of the plight of the female figure: "[Helen's] capture and her still-living presence is primary to Western tradition, from The Iliad to Cinder Ella to Faust to modern movies of tragic female stars who rise, fall, are murdered, rise again" (94). Here Grahn draws parallels between the present and past in a way anticipated by Eliot's mythical method. However, for Eliot returning to myth was a corrective measure; for Grahn it is to emphasize how little things have changed since that early time when women were first subjugated by men. Her mention of "modern movies" highlights this point. Although film can engender images of victimized women ("tragic female stars who rise, fall, are murdered"), as we shall see, Helen's status as a film star can also be a source of empowerment in the agency that celebrity affords her.

The Queen of Wands' "Helen in Hollywood" is the poem's most straightforward examination of the way women are depicted in popular culture. Grahn describes the modern-day Helen: "[s]he writes in red red lipstick / on the window of her body, / long for me, oh need me! / Parts her lips like a lotus" (46). The emphasis on cosmetics in these lines appears to parody the imagery found in popular culture projections of female beauty. This passage sustains Grahn's argument that women remain objects onto which men project their desires. However, in her book Blood, Bread, and Roses Grahn discusses the importance of cosmetics in ancient menstruation rituals. ${ }^{20}$ She notes that

\footnotetext{
${ }^{20}$ She notes, "the Greek word cosmetikos [carries the] dual meaning of a 'sense of harmony and order' and 'one skilled in adorning,' from cosmos, meaning both 'ornament' and 'the universe as a well-ordered whole.' Expanding on this I use cosmetic metaform to mean the ordering of the world through descriptive use of the human body action, artful movement, shape, ornament, and decoration" (22-23). Angus Fletcher similarly notes how "kosmos" includes notions of "ornament" and to "adorn" in Allegory: The Theory of a Symbolic Mode (117-18).
} 
"[1]ipstick [...] may be considered the first cosmetic" because cosmetics "began as simple signals of warning and instruction, enabling women to control how they were seen, whether they were avoided or approached. The woman didn't need to display her vulva, she could paint her mouth with menstrual blood" (75). She argues that the basis of contemporary society can be found in the way menstruation ordered civilization. She writes, "[i]n considering menstruation as female power, in contemplating creation stories and the uniqueness of the human capacity for elaborating culture, I fashioned a new myth of origins" (7). With her self-conscious revelation of a desire to create a "new myth of origins" in mind, the lipstick can be viewed as a symbol of female power, the survival of a ritual from an older, woman-centered time, even if the line "long for me! oh, need me!" clearly bears traces of irony. This irony illustrates the ambivalence of much of the poem: there is the recognition that as she draws on her lipstick, Helen may not be aware of what she does, unlike her creator, Grahn, who painstakingly peers into the past to identify the cultural power Helen has lost without realizing it.

Reading the lipstick passage we also recall the dedication of the book -- "[t]o Marilyn Monroe / who tried, I believe / to help us see / that beauty has a mind / of its own" -- which does not appear to carry any hint of irony. If Monroe, as the oversexualized image of the ideal American woman, strikes us as odd for a dedicatee to such a clearly revisionist text, it may be because we fail to fully grasp Grahn's argument. It becomes clearer as the poem goes on. She writes,

We infuse her.

Fans, we wave at her

like handmaids, unabashedly, 
we crowd on tiptoes pressed together

just to feel the fission of the star

that lives on earth,

the bright, the angel sun

the luminescent glow of someone

other than we.

Look! Look! She is different.

Medium for all our energy

as we pour it through her. (46-47)

Here again Grahn expresses ambivalence: on one hand she admires the strength of figures like Monroe who can act as a "medium" for "our energy," on the other regretting the way this individual is reduced to her parts ("her lips like a lotus") and who must be forced to bear the burden of being a "bright, angel sun" with a "luminescent glow" by her "fans." "21 Yet a few lines later in the poem, the speaker directly acknowledges our debt to this modern day Helen: "[s]he is the symbol of our dreams and fears / and bloody visions, all / our metaphors for living in America. // Harlowe, Holiday, Monroe // Helen / When she goes to Hollywood" (47). Helen's image, insofar as it is a "metaphor for living in America" performs an important function in allowing us to understand ourselves and to identify the values that underpin American society, even if one of those values appears to be a superficial obsession with physical beauty. For all the love of surfaces in American society, there persists the irony that the American "commodity culture" of cosmetics has

\footnotetext{
${ }^{21}$ In another poem, Grahn writes, "I have come to claim / Marilyn Monroe's body / for the sake of my own" (Work of a Common Woman 31). The speaker promises to "take [Monroe] in this paper sack / around the world, and / write on it: -- the poems of Marilyn Monroe --" (32). The poem, like "Helen in Hollywood," is clearly an attempt to recover the archetypal American woman and concludes with an image of the poem's speaker striking men with Monroe's bones.
} 
its roots in ancient menstruation rituals. It is thus by being mindful of past practices that Grahn appropriates the power taken from women by men who presumably continue to be the decision-makers in Hollywood and in the cosmetics industry.

In the final analysis, this Helen is decidedly greater than the sum of her parts. The poem's speaker stresses,

She is far more than a product

of Max Factor,

Max Factor didn't make her

though the make-up helps us

see what we would like

to take her for[.] (48)

What we should "take her for," in Grahn's estimation, is a figure with a multiplicity of identities, not all of them flattering:

she who is princess and harlequin, athlete and moll and whore and lady, goddess of the silver screen the only original American queen

and Helen when she was an angel when she went to Hollywood[.] (49) The poem ends here; we do not find out, grammatically speaking, what happened "when she went to Hollywood." Nevertheless when Grahn calls her "the only original American 
queen" we sense that while she recognizes the ways in which movies and the glamourinspired entertainment industry might be guilty of perpetuating those historical grievances Grahn levels at Western society as aftereffects of the Trojan War, she also attributes a certain agency to the role of being a "goddess of the silver screen." It permits a return to an elevated status which promises the possibility of being a "symbol" through which we can work our way into a future informed by the past. That is, if we identify both the subjugation of Helen and also her untapped power, we begin to recognize not only the cultural ills associated with her, but also that she has the potential for regaining the power she once possessed. It will be the work of The Queen of Swords to fully restore her to her former glory.

The volition we witness emerging in Helen in the final lines of "Helen in Hollywood" is carried over into the last sequence of The Queen of Wands where cosmetics, as earlier in the poem, are appropriated as symbols of power. Its speaker, known only as "Annie Lee" (presumably another modern version of the name Helen ${ }^{22}$ ),

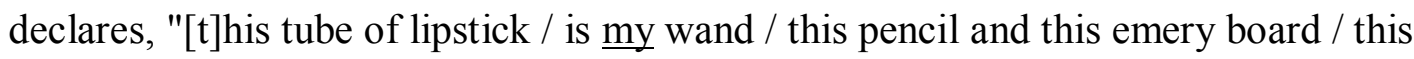
mascara applicator / brushing black sex magic [...] these knitting tools for putting things together are my wands" (90). These objects, commodities produced to impose a popular culture sense of beauty and domestic duty on women, are unexpectedly taken by the female speaker to be emblems of power. The emphasis on "black sex magic" and the transmutation of the "knitting tools" into magical wands brings the poem full circle in its interest in occult symbols. Here the occult (the "black magic") and the popular culture

\footnotetext{
${ }^{22}$ This might also be an ironic allusion to Edgar Allan Poe's "Annabel Lee," a poem that records the doomed relationship of its speaker and his lover. We might also recall Poe's "To Helen" which speaks of the "glory that was Greece / And the grandeur that Rome." It is clearly against this classicism that Grahn's project works.
} 
(the "tube of lipstick," etc.) motifs find a final, lasting image that unites them to the book's title: The Queen of Wands.

With its mixture of disparate sources which vary from imagery drawn from the cosmetics industry and movies to the persistence of women in traditional myths, The Queen of Wands sets the stage for the next installment of Grahn's Chronicle of Queens. The Queen of Swords will literalize what is generally only metaphorical in The Queen of Wands: Helen will continue to develop from the indignant, but still compromised figure in The Queen of Wands to one who secures an identity that symbolizes a reconstitution of women into positions of power in society in The Queen of Swords. A major difference between the two texts, however, is that Swords utilizes more formal play, a dominant characteristic of postmodern literature that is evident in a number of other long poems from the latter half of the twentieth-century. ${ }^{23}$

\section{The Queen of Swords: The Transformation of a Goddess}

If The Queen of Wands maintains some distinction between the modern Helen who appears in popular culture personages like Marilyn Monroe and the Helen-figure of ancient myth, The Queen of Swords represents a complete collapse of time and space in which the ancient, mythic Sumerian past paradoxically occupies the present. The two eras are combined to produce something of an alternative reality in which sexuality is

\footnotetext{
${ }^{23}$ Texts in this vein include those by Dorn, Koch, Merrill and the others cited earlier. Paul Muldoon's Madoc: A Mystery (1991) might be another example of this kind of long poem. In Madoc the aspirations of S.T. Coleridge and Robert Southey to found a utopian community in northern Pennsylvania are tempered by a frame narrative which involves a science fiction-style alien attack. Perhaps even more relevant to Grahn's interests is the other long poem from the period to use Sumerian sources: The Tablets by Armand Schwerner, which we looked at briefly in our introductory chapter. We will recall that Schwerner's poem uses linguistic and textual play to question the modern perspective we inevitability bring to any historical document. Like Schwerner, Grahn will foreground wordplay in The Queen of Swords.
} 
freer and uninhibited by patriarchal prohibitions. ${ }^{24}$ This is not to say that one enters this "reality" at will. In fact, part of the purpose of the play is to show how the initially heterosexual Helen is converted into a realized individual as a lesbian through an intense struggle. There is an awakening in Helen, then, one which aids her in regaining the position of authority she once maintained; her sexuality is apparently a key to the selfrealization that offers her power in modern-day society.

The Sumerian goddess known as Inanna becomes Swords' Helen figure. The play dramatizes Inanna's journey into the Underworld. ${ }^{25}$ In the original tale, Inanna descends to the land of the dead to bolster her already considerable powers and emerges more formidable than before. However, as payment to Ereshkigal (the female deity in charge of the Underworld who permits this empowerment), Inanna must elect someone to take her place and this duty is finally divided between her husband, the bull god Dumuzi, and his sister, each of whom serve half of every year. For Grahn this myth recalls a time before women were enslaved (both literally and metaphorically) in the age of Homer. In her introduction to the play, Grahn relates Inanna to the Helen figure. She discusses the fallout of the Trojan War and notes Helen "ran for cover under the relentless authority of the all-male monotheism that gradually replaced her worship during these last few centuries" (1). She then observes "Helen did not really die [...] and will return to us when we are ready" (1). That the origin will somehow "return to us" echoes Graves" similar expression of hope, at the end of his book, that the White Goddess would reappear. Like Graves before her, Grahn will posit the importance of remembering in The Queen of Swords as a way to accommodate the return of an earlier, and presumably

\footnotetext{
${ }^{24}$ We might recall how sexuality in Charles Olson's Sumerian translation that we reviewed in chapter one is similarly less inhibited, although Olson would certainly appear a patriarchal figure to Grahn.

${ }^{25}$ A translation of this tale by Betty De Shong Meador is appended to the play.
} 
better, way of thinking. In fact $\underline{\text { Swords }}$ can be read as an allegory intended to illustrate the procedure by which the forgotten history of women can be recovered. The figure of Inanna / Helen is clearly intended as exemplary. She gains a better perspective on her past as the text progresses and draws on the strength of her female companions to help her complete her transformation.

The revisionary nature of Grahn's play becomes apparent in the change she makes to the setting of the ancient story. The Underworld in Grahn's tale is underground only in a metaphorical sense: it is a lesbian bar and Ereshkigal notes "here in the belowworld Lesbians are loved, / and Lesbians love" (48). In The Queen of Swords the use of myth allows the present to be the site of the ancient as Eliot intimated in his comments on the mythical method, but certainly there is a new spin on an old theme here. The popular culture setting -- or what might be better called a "sub-culture" setting, as Johanna Dehler suggests ("Lesbos Revisited" 213) -- allows Grahn to bring myth into a situation that throws light on the present; not as an illustration of how "futile" and "anarchic" our current society is, as Eliot stated, but rather to permit us to recognize the ways in which we can improve our culture. The usefulness of Sue-Ellen Case's neologism "neomyth" in capturing the self-conscious reinterpretation of myth in The Queen of Swords is apparent in the new dynamic that a preoccupation with alternative sexualities brings to the ancient story. Grahn does not wish to purely resurrect the past but rather to embellish it with contemporary concerns.

The only significant alteration to the content of Inanna's tale is that it is Dumuzi's girlfriend, instead of his sister, who shares his duty to remain in Ereshkigal's Underworld. Grahn explains that her adjustment to the earlier text is due to the nature of our 
"fragmented culture" which does not contain a situation equivalent to the original (167). However, it seems more likely that Grahn wishes to rationalize Inanna's dismissal of Dumuzi to the Underworld in her place. This action receives no real explanation in the original tale; instead Dumuzi seems unjustly punished for Inanna's greedy desire for greater power. In Grahn's version, Dumuzi's guilt of infidelity is repaid with a fitting punishment, making the story's outcome more reasonable to modern readers and more consistent with her project to diminish the status of men so women are elevated to assume their positions of authority.

The play begins by representing Helen's feelings of ineffectualness. She laments: "[a] queen am I / Queen Helen is my office. / Yet trivial is how I feel. / Venus of what universe am I? (16). After her articulation of dissatisfaction with her current life is quietly dismissed by her husband, Helen decides to strike out on a "journey" (18). This journey takes her to the "Underworld" bar owned by Ereshkigal. Ereshkigal's characterization of herself to Helen emphasizes her ubiquity in popular culture: "you've seen me glaring in fury from some picture / in the newspaper, taken in some jail, you've seen me / in the grade-B movies [...] I played your older / sister Clytemnestra once, in a violent Greek play (24-25). The reference to the "B movie," or the photo of Ereshkigal in jail, suggests the way she has been marginalized in contemporary society -- we are in the presence of "Helen in Hollywood" no longer. This is not to say Ereshkigal fails to see the light of her situation: her presence in a second-rate movie appears to be worn as a badge of honor and at one point she calls herself the "Butch of Darkness" -- an example of the kind of playful humor we will see more of momentarily (51). From "grade-B movies" to a "violent Greek play," Grahn has little difficulty moving from modern day kitsch (the B- 
movie) to the "high" culture of ancient Greek tragedy; these distant points on the spectrum of products of culture coexist in Grahn's work with little conflict. For Grahn, as Edward Dorn says, "one thing [is] as good as another [...] as source."

In contrast to the individuation and self-deprecating sense of humor Ereshkigal reveals in dubbing herself the "Butch of Darkness," Helen must work at gaining, or rather re-gaining, a distinct self-image. ${ }^{26}$ Over the course of the play Helen must be reminded of her former glorious place in pre-patriarchal culture which she has slowly forgotten over time. Ereshkigal tells Helen: "[y]ou were a goddess before Demeter's time, / Lady Venus of aboveworld form, / Inanna by name, Sumerian born -- / you passed through seven gates of the underland / to deliver yourself into my hands, / into Ereshkigal's hands" (51). A number of characters enter the play solely to help Helen in this complicated process of remembering. The host of figures includes Amazon warriors who tell her, "Helen, your forces / are in the beauty of your memory" (69). The choice of the term "forces" here gestures toward the paranormal nature of Helen's powers appropriate to an ex-goddess and, in a more contemporary way, suggests occult practices which I have already noted to be the byproduct of goddess worship in our age. The term also evokes the image of a military formation, with Helen at its head, presumably assembled to recover Helen's supremacy by whatever means necessary.

The theme which persists in much of Grahn's work -- the West's forgetfulness of its past -- runs throughout the play. Among the few male figures in The Queen of Swords is Enki, whom Grahn notes is the "god of wisdom and nature" (9). In a revealing

\footnotetext{
${ }^{26}$ To Grahn's mind, Ereshkigal is an archetypal figure whom like Helen persists over the ages: "[i]n later stories Ereshkigal was vilified, and her human counterparts were burned at the stake, tortured, and driven underground; she remained in variants of the Inanna stories as 'the wicked queen,' the 'dark Morgan, Queen of Fairy' (Morgan Le Fay), 'the evil stepmother,' and so on” (164).
} 
metaphor, he likens modern consciousness to that first device of electronic mass media technology, the radio: "I have watched human beings / thinking they think. / Really, they hear. / Tuned into radio bands / of collective understandings" (73). The metaphor of human thinking as a radio suggests that the passivity inherent in popular entertainment has the potential to make us forget, or perhaps further exacerbate the forgetting we have already done, and we must work hard to remember. Remembering entails considering how we might recall that distant time in which the influence of women was usurped by the machinations of men. That we have forgotten this cultural moment of female dominance is certainly one of the negative effects of the modern age. Recognition of the shortcomings of contemporary culture helps the play qualify its embrace of the popular. The "collective understandings" Enki mentions is evocative of the Jungian "collective unconscious" that makes other appearances in The Queen of Swords. ${ }^{27}$ These "collective understandings" suggest a uniformity of thought in humanity that seems to explain for Grahn the persistence of the Helen figure -- even if she has lost much of her social standing over time.

The play's version of a Greek chorus, its crows, ${ }^{28}$ represent a certain postmodern abandon to the pleasures of subversive wordplay. Grahn's crows possess a fluidity of identity which is apparent in her description of them in the list of dramatis personae: "Seven Crows, variously crows, dikes, Amazon warriors, motorcyclists, judges, demons" (9). Like their constantly fluctuating identity, the speech of the crows is marked by a

\footnotetext{
${ }^{27}$ Elsewhere Ereshkigal speaks of the "four kinds of memory" Helen must work on recovering, the third of which she tells Helen is "the collective, consciously connected / recollections of your kind" (97; 98). This emphasis on the "conscious" nature of the "collective" imagination appears a revision of Jung's famous "collective unconscious." It speaks to the process of actively remembering that Helen dramatizes in the text.

${ }^{28}$ Another long poem from the period uses crows in an examination of alternative religion and myth, namely Ted Hughes' Crow (1971). One could point to other crow imagery persisting across the ages, from Aristophones' The Birds (414 BCE) to the racist crow “chorus” of Disney's Dumbo (1941).
} 
number of linguistic and semantic slippages which suggest an instability of the signifying system. The very denotative capacity of language itself is thus questioned, especially in Scene Two where the confidence Helen is gaining in her memory causes her to grow more aggressive, both verbally and physically. Her new physicality is manifested when she begins brandishing a sword. The crows offer an amusing commentary to complement the action, calling Helen by one of her other names, "Venus":

\section{Crow}

What is Venus doing I wonder?

\section{Crow}

She's doing some swordplay.

Crow

She's handling a big pricking stick.

Crow

That's cutting.

Crow

It's CAWstick.

Crow

She's practicing being a matador.

Crow

She's spearing Taurus.

Crow

She's trying to cut through all the bull. (80-81) 
The term "swordplay," minus its initial letter "s," is of course "wordplay" and as Helen practices her sword work the crows practice their word acrobatics. Here the proverbial sense of "cutting through the bull," or getting to the heart of a matter, acquires an ironic sense in light of the fact that Helen's husband is Dumuzi, the bull god. One way of reading this passage is to conclude Helen is mimicking slaying him with his own phallus ("big pricking stick") and this passage recalls the phallic imagery present in the "wands" imagery of Grahn's earlier long poem. Clearly this appropriation of the sword is an act of empowerment, but it is rendered in a context of puns which evoke a distinctively postmodern playfulness. One finds exchanges such as this in other long poems from the period such as in the texts of Merrill, Dorn, or Koch. The dialogue of the crows in this scene furthers the playful elements of the text we saw earlier, for instance, in Ereshkigal's characterization of herself. There is little doubt Grahn believes in the importance of her message, but she uses the crows to qualify the imagery and symbolism of the play so that Helen's handling of a "big stick," for instance, does not trouble the reader (or viewer) as naively Freudian. Self-consciously tongue-in-cheek moves such as this go quite a distance toward making Grahn's pursuit of an alternative origin appear more fair-minded and well-considered because she takes pains to indicate to us that she is aware of the overtones and implications of her work.

Slightly later in the text, the crows call attention to the "low" nature of their humor by commenting on their consistent use of puns:

\section{Crow}

I hate puns --

$\underline{\text { Crow }}$ 
How ungrateful --

\section{Crow}

The Gateful Dread --

\section{Crow}

A pun is the lowest form of twit --

\section{$\underline{\text { Crow }}$}

All life is hereby condamned to death--

\section{Crow}

Condomed to which?

\section{$\underline{\text { Crow }}$}

A condomnation of death to life -- (96)

This dialogue, which is only a short excerpt of pages of puns which appear in the play, comes in the middle of Helen's transformation in a section called "Judgment of Helen" -itself a pun on the phrase the "Judgment of Heaven" (as well as an inversion of the "Judgment of Paris," the ultimate cause of the Trojan War). Here Helen is trying to recover her memory through much struggling, although the process appears to be working as Ereskigal tells her "you're on your way to being a goddess, / of sagacity, at least" (97). This important change in Helen's person is contrasted with the inane chatter of the crows which consists of an allusion to a popular rock band, The Grateful Dead, whose name is transmuted into a pun on the various "gates" Helen must pass through in her metamorphosis. This is in addition to wordplay ("condamed to death") that adds very little to our understanding of Helen's situation. The flippant humor of the crows, then, is starkly contrastive with the life-altering process Helen goes through in increasing her 
power. Ultimately, the crows help Grahn qualify her work by adding a dimension of selfawareness that acknowledges the potential skepticism of the reader or viewer. She signals to us, through the crows' subversive word play, that she recognizes the leap of faith she asks of us in regarding Helen's attempt to overcome centuries of gender inequity through the simple process of remembering her past.

The images of popular culture - the B movie, the radio, the rock band - that persist in The Queen of Swords help to validate Grahn's originary approach. Were she to produce "neomyths" without trying to show how they correspond to the current era, if they were placed in some imagined mythic past as H.D. does in Helen in Egypt, it would be more difficult to grasp the relevance of her argument. An awareness of the historical significance of cosmetics in The Queen of Wands, for instance, helps tie "Helen in Hollywood" to ancient women-centered rites. On the other end of the spectrum, tonally, the playful aspects of The Queen of Swords further the "contemporaneity" of myth by imposing a late twentieth-century sense of humor that works to qualify the mythmaking process. In both cases, the return of the goddess is ultimately shown to be a process of remembering in our time and it is within the power of women to help each other remember, as The Queen of Swords takes pains to dramatize. This remembering is to be embellished with a recognition of the alternative lifestyles available to women now that further their independence from men.

A Chronicle of Queens is thus a fusion of disparate sources and impulses: ancient myth, Hollywood, lesbian revisionism, rock bands, and the tradition of the long poem, not to mention a self-conscious (re)construction of origins all meet in its pages. We can situate Grahn's project within the context of the postmodern long poem and its 
practitioners who integrate popular culture into the matrix of the poem where modernism sought to escape the popular and retreat into the sanctity of high culture. Grahn is one among many, then, who bridge the gap between high and low. As we shall see with Derek Walcott in the next chapter, she also gives voice to the historically marginalized and through this process offers them a mythology not subject to the conditions imposed by patriarchy. She has indeed forged "a new myth of origins" for later writers to use as their own starting place and has given women a method by which they can regain, and amplify, their forgotten power. 


\section{Chapter Three}

\section{"Master, I Was the Freshest of All Your Readers": Derek Walcott's Omeros and Homer as Literary Origin}

\section{Derek Walcott, Omeros, and Postcolonialism}

Derek Walcott's reputation was enhanced by winning the Nobel Prize for Literature in 1992 and today he remains a vital force in world literature. His work is important for many reasons, not the least of which is for the position from which he speaks: as a poet hailing from the small Caribbean island of St. Lucia. As he points out, the island has been called "Helen of the West Indies" because of the contests waged between England and France over its territory (Sampietro). St. Lucia's history informs Walcott's poetry, particularly as his work examines the aftereffects of imperialism. Although the term "postcolonial" has been used in many ways, we might profitably label Walcott a postcolonial poet if we keep in mind the definition of the term offered by Ashcroft, Griffiths, and Tiffin. ${ }^{1}$ These critics look beyond the prefix "post" in postcolonial as meaning only "after-independence" for past colonies (2). Instead, they write, "post-colonialism is a continuing process of resistance and reconstruction" and is "based in the 'historical fact' of European colonialism and the diverse material effects to which this phenomenon gave rise" (2). It is with the thought that postcolonialism is a "continuing process" that I use the term and, as we shall see shortly, Derek Walcott's book-length poem Omeros (1990) very clearly works through issues related to European colonialism's continuing influence on St. Lucia.

\footnotetext{
${ }^{1}$ It is worth noting, as evidence of Walcott's status as a recognized postcolonial thinker, that Ashcroft, Griffiths, and Tiffin include his prose piece "The Muse of History" in their Post-Colonial Studies Reader.
} 
There is another side to Walcott's work which also begs our attention, apart from the exposition of imperialism and colonialism that dominates many of its pages. I am thinking of the playful, self-reflexive aspect of many of his poems and plays. This characteristic has been noted by John Thieme who remarks, "[m]uch of [Walcott's] work is metaliterary, a self-conscious discussion of the problematics of Caribbean writing and an attempt to evolve suitable forms for the rendition of his own Caribbean experience" (2). The play between artifice and content in Walcott's work will be my focus here as I look into the ways in which self-reflexivity qualifies Walcott's critique of the European and African origins of St. Lucia in Omeros. Ultimately Walcott must resist originary thinking because it does not offer a way for the island to move forward; in fact, the one character in the poem who remains willfully preoccupied with origins, Achille, shows the smallest personal growth by the close of the book.

As Walcott's major work, Omeros stands as one of the most intriguing re-castings of Homer's epics The Odyssey and The Iliad in the twentieth-century. This process of revivifying older texts persists throughout Walcott's oeuvre, including his transformation of the Don Juan story in The Joker of Seville (1974) and his Caribbean-influenced stage version of The Odyssey (1993). At once both a homage and a subversion, Omeros is ambivalent about its precursor texts: elements of them persist within the poem, but with consistent adjustments and reconfigurations. The narrator of Omeros, who also happens to be one of its major characters, feels that the primary figures of The Iliad -- Hector, Achilles, Helen -- offer him a means for describing the social friction of St. Lucia. Yet he is also dubious of the historical legacy of empire which influences the actions of these characters. The narrator draws parallels between Homer's ancient poems and his own, 
not only in the characters they share but also in the way they work with themes of social contest and foreign occupation. The Iliad, especially, stands in Walcott's thinking as a "poem of force," as Simone Weil memorably calls it (45).

In Omeros Homer represents the legacy of the West haunting writers like Walcott who have been both historically marginalized but also influenced by European literature. The quotation that forms part of my title, which the poem's narrator addresses to the figure of Homer, alludes to this: "Master, I was the freshest of all your readers" (283). I will be turning to the relationship between the narrator and Homer shortly, but suffice it to say now that Homer is a "master" in the literary sense, in that his work is the source from which Walcott's derives. The term "master" also calls to mind the colonizer / colonized relationship and, in the process of Walcott using the term, it is ironized: Homer, the "original" "master" must now rely on Walcott for his voice. With St. Lucia as his setting and through the interactions of characters lifted from The Iliad, characters of Walcott's own invention like Major Dennis Plunkett and his wife Maud, as well as a manifestation of Homer himself as "Omeros," Walcott builds a narrative that works as a meditation on a Caribbean writer's relationship to a European literary heritage. Through this process he is able to critique the drive for empire which has rested at the heart of European endeavors around the world.

The ways in which imperialism controls the perspectives cultures have of one another has been famously examined by Edward W. Said in his groundbreaking book Orientalism. Said argues that the notion of "Orientalism" is a construction of the West that illustrates the way one part of the world (here "Europe") defines another (the “Orient"). Constructions of this kind, what he calls "the formidable structure of cultural 
domination," are always invested with particular ideological ends in mind (25). He remarks that Orientalism is "a created body of theory and practice in which, for many generations, there has been considerable material investment" (6). There is, in other words, no objectively existent "Oriental"-ness, but rather a cultural identity invented by those who seek to categorize others. The result of this process is to make one group of people, the "Oriental," the object of another, the "Occident." This relationship is ultimately one based on what Said terms "configurations of power" through which Europe can reinforce its vitality by comparing itself to a "weaker" Orient (5).

Said continues his study of the effects of "cultural domination" in Culture and

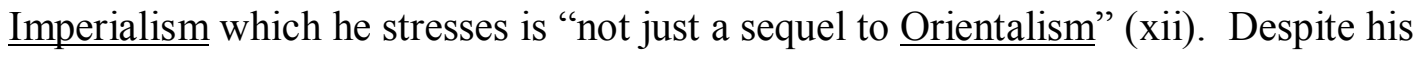
protest the book does continue, albeit in a broader sense, the project he began earlier by investigating the manner in which the imperial past of three countries -- Britain, France, and the United States -- has shaped world events. Said tells us, "[a]t some very basic level, imperialism means thinking about, settling on, controlling land that you do not possess, that is distant, that is lived on and owned by others" (7). In Omeros this impulse will be represented by the characters of Maud and Major Plunkett who persist on the island despite the ending of Britain's active colonization of it. Also relevant to our study of Walcott's poem is Said's insight that “[p]artly because of empire, all cultures are involved in one another; none is single and pure, all are hybrid, heterogeneous, extraordinary differentiated, and unmonolithic" (xxv). Indeed, one of the intriguing aspects of Walcott's poem is its desire to show how interwoven the history of St. Lucia is with European powers and the references to Homer illustrate this linkage. 
The other quality of Walcott's work we have mentioned, its self-reflexivity, is addressed in that other ubiquitous "post" in current critical theory, apart from postcolonialism: postmodernism. Linda Hutcheon points out that postmodernism is typically seen as "politically ambivalent" whereas postcolonialism, by definition, contains a "strong political motivation" ("Circling" 130). She concludes that the two share a number of strategies - irony, allegory, and self-reflexivity - which unite them (135). They also share a preoccupation with marginalized figures whom she calls the “ex-centric" (Poetics 60). Kwame Anthony Appiah similarly compares the terms and offers a useful view of the prefix shared by the two: "the post in postcolonial, like the post in postmodern is the post of the space-clearing gesture" (119). He writes that it is a "post that challenges earlier legitimating narratives" (123). Thus Appiah does not feel historically constrained by the "post" in postcolonial as Ashcroft and the others believed was the inevitable effect of the prefix. Instead Appiah sees the "post" as a way to distinguish the present from the past in a productive manner. Walcott's work is certainly "post" in the sense in that Omeros can be read as a "space-clearing gesture" in which the legacy of Homer and Western literature can finally be engaged with the intent to move beyond them. Yet the problems of empire are still tangibly present, a "continuing process" as Ashcroft, Griffiths, and Tiffin argue.

The question before us is how the postmodern self-reflexivity Walcott employs aids his examination of Homer. This question gets to the heart of the effectiveness of self-reflexivity. ${ }^{2}$ Is a literature which is so consumed with itself and its own mannerisms,

\footnotetext{
${ }^{2}$ In Terry Eagleton's view, postmodernism's self-reflexivity is one aspect of its general "depthlessness": "[t]he typical postmodernist work of art is arbitrary, eclectic, hybrid, decentered, fluid, discontinuous, pastiche-like. True to the tenets of postmodernity, it spurns metaphysical profundity for a kind of contrived depthlessness, playfulness and lack of affect, an art of pleasures, surfaces and passing intensities. [...]
} 
as postmodernism is sometimes said to be, also capable of addressing social concerns?

Can it still be a tool for political expression and indignation if it is also willfully selfobsessed? I suggest that self-reflexivity is operative in Walcott's poem to the extent that we cannot suspend our disbelief because we are constantly made aware of a narrator constructing the poem as it goes on. Through this self-reflexivity Walcott can both recognize his debt to Homer and acknowledge the Western cultural demands which are an obstacle for the poem's characters. The self-reflexivity works as a qualifying device, then, one which allows Walcott to remain cognizant of his own motives at the same time that he questions Homer's.

Finally, we should consider the aspect of postcolonial studies that Gayatri Spivak evokes in her famous article "Can the Subaltern Speak?" She asks if it is possible for the "subaltern," the oppressed colonial subject, to speak for him or herself within the colonial situation. In the end she remains dubious of the possibility, particularly as these individuals are co-opted by critical theory; she asks "[h]ow can we touch the consciousness of the people even as we investigate their politics?" (27). Looking at this issue from another point of view, Homi K. Bhabha calls our attention to the need to analyze those voices which emerge from imperial conditions. He argues,

if the interest in postmodernism is limited to a celebration of the fragmentation of the 'grand narratives' of postenlightenment rationalism then, for all its intellectual excitement, it remains a profoundly parochial enterprise.

Rejecting all attempts to reflect a stable reality itself, it exists self-consciously at the level of form or language" (Literary Theory 201). Fredric Jameson similarly posits the possibility that "[p]ostmodernism, postmodern consciousness, may then amount to not much more than theorizing its own condition of possibility" (ix). 
The wider significance of the postmodern condition lies in the awareness that the epistemological "limits" of those ethnocentric ideas are also enunciative boundaries of a range of other dissonant, even dissident histories and voices -- women, the colonized, minority groups, the bearers of policed sexuality. [...] It is in this sense that the boundary becomes the place from which something begins its presencing. (Location of Culture 45)

It is as a voice emerging from a historically marginalized position, along "the boundary" as Bhabha's metaphor has it, within European thought that Walcott speaks. His project entails giving "ex-centric" individuals voice, as Hutcheon advocates and Bhabha here calls on us to do. Indeed, part of the significance of Walcott's poem is its ability to dramatize postcolonial conflicts. The mutual identification which occurs between its characters by the end of the poem goes a long way toward showing how once different groups have gained a voice they can then work to find common ground for understanding one another, leading to an improvement in their shared postcolonial condition.

A number of studies on Walcott have thoroughly examined the Homeric parallels with $\underline{\text { Omeros}}$, so it would be superfluous for me to do the same here. ${ }^{3}$ While I will make

\footnotetext{
${ }^{3}$ As might be expected, Walcott's poem has received a fair amount of critical attention, particularly in regard to its status as a modern epic, or revision of the epic tradition. One of Walcott's most prolific critics, Robert D. Hamner, calls Omeros an "epic of the dispossessed" because of its utilization of characters representing those who have been historically marginalized. Lorna Hardwick analyzes the use of simile in Homer and Walcott and concludes it operates as a means for Walcott to engage his Homeric forbearer. Charlotte S. McClure examines the image of Helen in Omeros and determines that Helen reveals the tension between Homeric mimicry and originality in the poem -- Helen is an expression, in other words, of Walcott's debt to Homer as well as his desire to break away into "originality." Charles Locke also looks at the figure of Helen and comments on her relative silence, surprising in a contemporary poem. He decides, however, that the silence of Helen is indicative of Walcott's own place within the politics of literary marginalization.
} 
a few references to Homer's text as I go on, my primary concern is with what we find directly in Walcott; after all, Walcott claims to have never read the whole of Homer's poems in interviews. ${ }^{4}$ It is thus the idea of Homer, as much as Homer himself, which Walcott reacts against. ${ }^{5}$ I want to examine Walcott's relationship to the notion of the origin as it is manifested in the figure of Homer as well as in Achille's return to Africa. To do this I will first survey the intense self-reflexivity operative in the poem, particularly in regard to the ways in which it aids Walcott's narrator in engaging Homer. Then I will study how the notion of origin becomes conflated with naming in Omeros as the poem's protagonist, Achille, seeks to fabricate his own origin story. Finally I will look at how Walcott's qualified view of origins influences his relationship to the epic tradition. I will reveal the way in which Walcott employs self-reflexivity to engage a notion of origins that he wishes to acknowledge but also transcend.

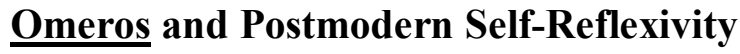

Before looking into the self-reflexivity of Omeros, I want to first consider its use with themes of epic, empire, and origins in a poem from Walcott's Selected Poems of 1964. This volume contains a piece appropriately titled, for our purposes, "Origins." The poem begins with its speaker commenting, "I came among olives of algae, / Foetus of Plankton, I remember nothing" (Collected Poems 11). In Omeros, the figure of Homer

\footnotetext{
${ }^{4}$ In his interview with Luigi Sampietro Walcott comments, "I don't know the history of Achilles' activity in the Iliad. Maybe I was scared of the Iliad because - I don't want to be swallowed up, in a sense, by Homeric comparison." Walcott reveals a Bloomean "anxiety of influence" here which helps explain his continual denial of any intimate knowledge of Homer. In the same interview he says, "anybody looking through my references - my associations - they're simple associations that everybody knows: Odysseus, the Eternal Wanderer; or Helen, the Eternal Beauty; or, in this case, Achilles, the Eternal Warrior; or Hector... These are just magnified, very ordinary symbols that everybody... Household names, really." ${ }^{5}$ Walcott makes reference to the series of "The World's Great Classics" at the end of Book I of his poem which alludes to the cultural capital assigned to particular texts as a result of their distribution as "canonical" works, such as Homer represents (71).
} 
will similarly emerge from the sea. We do not know the name of the speaker of "Origins," 6 but nevertheless he begins a catalogue of heroes from the classical epic and appears to address himself to a Homer-like figure: "I learnt your annals of ocean / Of Hector, bridler of horses, / Achilles, Aeneas, Ulysses" (11). The speaker thus positions himself as one responding to the epic tradition, but his lack of a specified identity (his "namelessness") does not permit us to situate him any further. After this invocation of epic heroes, the speaker of "Origins" offers an image with a strikingly textual basis: "[b]lank pages turn in the wind" (11). The metaphor utilized in this line ("blank pages") anticipates similar text-based images in Omeros. We surmise the pages are blank because they await a poet like Walcott to fill them -- that is, for the marginalized to be present among the literary characters (Achilles, Aeneas, etc.) who embody the apex of Western classical heroism. In this way Walcott responds to the project called for by Bhabha: he represents those whose story has yet to be written.

Walcott's desire to fill the "blank pages" of history becomes clearer in "Origins"” second section. The speaker comments, "[b]etween the Greek and African pantheon, / Lost animist, I rechristened trees" (12). The speaker looks to an alternative tradition, an "animist" one which will help him diversify his worldview outside of a Greek frame of reference. We will see shortly how Achille in Omeros will attempt to reconnect with his own African origins. Although "Origins" is largely hermetic, its speaker is clearly trying to recover some lost origin, and the second section ends with a reference to a "Guinean

\footnotetext{
${ }^{6}$ He says he is "nameless" (11). This anonymity suggests that his is a general, "public" voice. The advantage of this anonymity is that the speaker can speak for a wide group of people without his own motives for doing so becoming apparent. The disadvantage to this approach, of course, is that we do not know from where the speaker speaks. By contrast, in Omeros the narrator's position is quite evident and the poem works to foreground the point of view of its narrator. The issue of naming is apparent also in Omeros, as we shall see.
} 
odyssey" (12). The speaker's mind goes over what has been lost; he remarks, "I seek my own name and a man" (14), echoing Virgil's opening line of The Aeneid: "I sing of arms and of a man" (1). In contrast with celebrated characters like Aeneas, the poem concludes by fulfilling its promise to draw attention to the marginalized figures who do the work that goes uncelebrated:

We praise those whose back on hillsides buckles on the wind To sow the grain of Guinea in the mouths of the dead,

Who kneel in the open sarcophagi of cocoa

To hallow the excrement of our martyrdom and fear,

Whose sweat, touching earth, multiplies in crystals of sugar

Those who conceive the birth of white cities in a raindrop

And the annihilation of races in the prism of the dew. (16)

In "Origins" we thus find issues of race and social dominance discussed in a framework which makes reference to the figures of the classical epic - a strategy Walcott will adopt on a grander scale in Omeros. The self-reflexivity early in the poem (the blank pages) proves a memorable visual metaphor for those figures whose history has yet to be written; it will be Walcott's job to do this in Omeros.

At nearly 330 pages, Omeros contains ample space for the development of selfreflexive strategies which aid its examination of the postcolonial issues that are first raised in "Origins." The poem is notably most self-reflexive when describing the lives of the characters Walcott adds to those he draws directly from Homer, namely Major Plunkett and his wife. Early in the poem the narrator offers an aside that reveals the self- 
reflexive nature of his relationship to these characters: "[t]his wound I have stitched into Plunkett's character. / He has to be wounded, affliction is one theme / of this work, this fiction, since every 'I' is a // fiction finally. Phantom narrator, resume" (28). The call for the "phantom narrator" to proceed after the interpolation of the authorial voice draws attention to the "metaliterary" nature of Walcott's work (to use John Thieme's term). The reader is forced, in other words, to pay close attention to the way the poem constructs itself - there is little chance for us to be swept away by what is otherwise a rather conventional narrative. The narrator's commentary thus qualifies the figure of Plunkett: if he seems the stereotypical colonizer -- who dreams at one point of traveling over the expanse of the once British empire (90) -- it is because he is a necessary "fiction," a figure who must be present to represent the colonial history of the island. The wound "stitched" into Plunkett's character -- and here we might recall the Greek term "rhapsody," which means to "stitch together," as well as the fact that the Homeric singers were called Rhapsodes ${ }^{7}$-- provides balance to the wound borne by the native fisherman Philoctete. ${ }^{8}$ We learn of Philoctete's wound within the first two pages of the poem when he shows tourists "a scar made by a rusted anchor $[\ldots]$ puckered up like the corolla / of a sea-urchin" on his leg (4). The wounds suggest that both the colonizer (Plunkett) and colonized (Philoctete) are afflicted by the history of empire. The figures Walcott appropriates from The Iliad (including Philoctetes) are largely free from the self-reflexive commentary which Walcott applies to Plunkett and Maud. The reason for this is clear:

\footnotetext{
${ }^{7}$ See Gregory Nagy's discussion of these figures in Poetry as Performance: Homer and Beyond.

${ }^{8}$ Jahan Ramazani analyzes the significance of the figure of Philoctete and his wound in The Hybrid Muse. He writes, "[a]s graphic emblem of convulsive, bodily pain, the wound in Omeros memorializes the untold suffering of Afro-Caribbeans, yet as trope it inevitably poeticizes pain, compares this particular experience with others, and thus must either mar or deconstruct experiential uniqueness by plunging it into the whirlpool of metaphorical resemblance and difference" (71).
} 
Walcott wishes to foreground the additions he makes to the Homeric dramatis personae. This move exhibits reverence for Homer, even as it adds to the ancient poet's cast of characters.

To suggest the end of the age of imperialism, Maud, who reluctantly stays on at St. Lucia despite yearnings for her native Ireland, dies near the end of the tale. ${ }^{9}$ While Maud's death is one of the more touching moments in the narrative and is told in a sympathetic way by the narrator, it too is marked by a self-reflexivity which makes it difficult to read Maud as a "real" person instead of as a character intended for allegorical purposes. The narrator -- that fictional "I" -- notes when Maud dies, "I was attending / the funeral of a character I'd created; / the fiction of her life needed a good ending // as much as mine" (266). The fate of the poem's speaker is tied up with Maud's insofar as her death signifies an historical shift for him as the remnants of empire slowly fade away. We might recall the line the speaker of the poem utters to Omeros that we discussed a moment ago: "[m]aster, I was the freshest of all your readers." This declaration receives no real elaboration in the text, but we can gather that it is through his reinvention of Homer in a Caribbean setting that the narrator sees himself as able to read Homer in the "freshest" of ways. Maud's death similarly reflects the "freshness" of Walcott's reading: the aggression of the Greeks against the Trojans is not unlike the intrusion of the British into St. Lucia and by bringing about Maud's demise Walcott suggests this period of forced influence has reached its terminus.

The figure of Omeros in the poem, the "master" in both the literary and the colonial senses, offers an extended case study in self-reflexivity. Sometimes called

\footnotetext{
${ }^{9}$ The name of this character calls to mind Tennyson's expansive poem (Maud: A Monodrama [1855]) that tells the story of a narrator who loses his sanity over love for a woman called Maud.
} 
"Seven Seas," he fails to appear fully in the text until relatively late, at which time it is the narrator's task to update the ancient poet on the changes that have occurred since his passing so many centuries ago. Despite his late appearance, he is anticipated early on, as in the following passage from the poem's second chapter: "므 was the conch-shell's

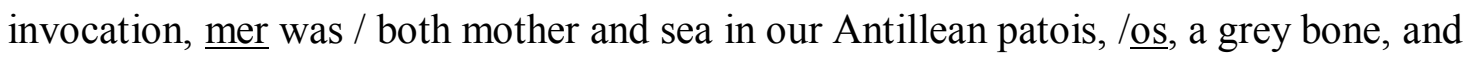
the white surf as it crashes / and spreads its sibilant collar on a lace shore" (14). The emphasis on the morphemes that make up Omeros' name ("O," "mer," "os") suggest he is composed entirely of text; here again, like Maud and Plunkett, we tend to read Omeros more as literary trope than as a dynamic character. When Omeros finally does appear, he rises from the sea, which the metaphor in Walcott's "invocation" foreshadows. This is only one of many references to the sea, another of which we will study in a moment. These references remind us not only of the geographical boundaries of St. Lucia but they also suggest the timelessness of the ways of life on the island that reflect themes which first appear in Homer. One of these themes is the sea voyage as a metaphor for the course of life, which will appear in Achille's search for origins.

The poem is fashioned out of terza rima-like stanzas which are undoubtedly intended to call to mind The Divine Comedy. Invoking Dante's canonical poem adds yet another difficulty to an already complex task of deciding how $\underline{\text { Omeros relates to the }}$ generic expectations of the epic. We are aided in this task, however, by the interaction between Omeros and the narrator. Near the poem's end Omeros plays Virgil to the narrator's Dante: the narrator must undertake a journey to an underworld, an Inferno of sorts, which is inhabited by past poets. Here he is forced to confront the demands of his vocation. Omeros explains, 
Your wanderer is a phantom from the boy's shore.

Mark you, he does not go; he sends his narrator;

he plays tricks with time because there are two journeys

in every odyssey, one on worried water,

the other crouched and motionless, without noise.

For both, the "I" is a mast; a desk is a raft

for one, foaming with paper, and dipping the beak

of a pen in its foam (291)

The problematic nature of the "I" in narrative poetry, reiterated here again, was also emphasized in the passage on Plunkett's wound we reviewed a moment ago. The metaphor is telling: the "I" and his narration are compared to a sea craft, drawing to mind the voyage of Odysseus. There is another ramification of the metaphor as well: if the labyrinthine voyage of Odysseus is taken as an emblem for the circuits in life one must travel to reach enlightenment, it is also indicative of the tangled process of writing, especially when one attempts to engage one's literary progenitor as directly as Walcott seeks to do in this poem. The "I" is both a metaphor for the impulse that drives the narration (as the mast on which the sail is hung) as well as visually evocative of the mast itself. In this way the "I" goes from being one kind of sign (a symbol) to another (an icon). Walcott's recognition of the arbitrariness of the sign enables him to question his own enterprise. If language involves the kind of connotative and denotative slipperiness 
suggested here, how can he use it to adequately represent his narrator's relationship to the past, especially to a literary juggernaut like Homer?

The answer to this question seems to lie with the poem's self-reflexivity. The self-awareness it confers on the poem helps to keep Omeros from naively interpreting its relationship to the past. For instance, when we recall the genre to which the poem is typically assigned -- the epic -- Omeros' self-reflexive nature is all the more important. I want to return to the implications that come with calling Omeros an epic at the end of this chapter. Suffice it to say now, however, that the poem uses self-reflexivity to question its epic leanings:

The ocean had

no memory of the wanderings of Gilgamesh, or whose sword severed whose head in the Iliad.

It was an epic where every line was erased

yet freshly written with sheets of exploding surf

[...] it drenched every survivor

with blessing. It never altered its metre

to suit the age, a wide page without metaphors.

Our last resort as much as yours, Omeros. (296) 
This passage calls on the reader to remember the sea imagery employed earlier in the text, in the references to Homer's name as well as in the image of the speaker's desk as a raft. Like the ocean, which has no concern for the changing styles or conventions of human society ("it never altered its metre"), the conflicts of Walcott's poem work to show how the history of cultural aggression, which is a condition not only of empire but

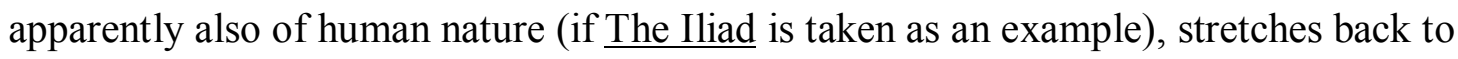
Homer's time and perhaps beyond. Walcott's self-reflexivity might be a factor of his postmodern condition but it ultimately allows him to be more mindful of his place in the continuum of world literature and stress how the postcolonial circumstances St. Lucia finds itself in are symptomatic of the history of the West from Homer's age forward.

If self-reflexivity is taken as a premier strategy of postmodern writers, as Linda Hutcheon suggests, we can begin to see, judging from Walcott's example, how it can help qualify a writer's perspective on origins. While self-reflexivity, like postmodernism in Hutcheon's view, is "politically ambivalent" in and of itself, it clearly can be used to political ends. The precedent we see in "Origins," which uses postmodern self-reflexivity to draw attention to the marginalization of particular groups of people, is carried through in Omeros. Walcott answers Bhabha's call for postmodernism to go beyond only disrupting "the 'grand narratives' of postenlightenment rationalism" by speaking for those who have been historically underrepresented. To illustrate how Walcott uses a direct critique of origins in Omeros to complement his work with self-reflexivity, I would like to now focus on two of the main characters of Omeros: Helen and Achille. My central question is if Walcott is successful in disrupting the "grand narrative" of narration itself, of calling into question the stability of the literary text by pointing to the instability of 
language from which it is built, can the poem also address the social problems of the island in a manner which sheds further light on its relationship to the rest of the world?

\section{Helen, Achille's Search for Origins, and the Politics of Naming}

We have seen how concepts like "history" and "empire" are important in Omeros and indeed the terms themselves are repeated throughout the text. ${ }^{10}$ With the consistent repetition of these words Walcott is able to condition our reading of the poem: their reiteration ensures that the reader will stay attuned to them, even as he or she attempts to follow the plot as it unfolds. The terms work together, then, as a device to aid us in understanding the degree to which the legacy of Homer, as a representative of the West, as an image of what Said calls "cultural domination," is an obstacle for the narrator. The narrator asks, "when would it stop / the echo in the throat, insisting, "Omeros"; / when would I enter that light beyond metaphor" (271). In some sense the poet is confined by his own "metaphor": if Homer is conceived as the origin from which Walcott's narrator descends, this direct address to the classical poet can be regarded as a way of contending with his historical legacy. On the other hand, the poet is also indebted to Homer because his poem would not exist otherwise, depending as it does on the appropriation and recasting of Homer's characters.

If we recall Homer's Iliad, we remember that his epic begins with a conflict between Achilles, the Greeks' greatest fighter, and King Agamemnon. Agamemnon is told by the gods to return the stolen daughter of a Trojan he has taken and out of resentment he snatches away Achilles' bride for his own. This leads to Achilles' "rage" -

\footnotetext{
${ }^{10}$ The reevaluation of history occurs in other book-length poems from the latter half of the twentiethcentury, perhaps most obviously in Robert Lowell's History (1973) and in works such as Pablo Neruda's Canto General (1950) and Galway Kinnell's The Book of Nightmares (1971).
} 
the very first word in the poem and a term that is repeated consistently over the duration of the story, like Walcott's own use of "history" and "empire" - and his abandonment of his fellow Greek warriors. By contrast, the conflict in Omeros centers on the desire for Helen shared by Achille and his rival Hector. This Achille, however, is quite different from his Homeric namesake: Walcott's Achille is a rather diffident main character who only takes action when he embarks on a quest for his origins. We have already noted that two characters of Walcott's own invention, Major Plunkett and his wife Maud, are representatives of colonizing forces in the poem. Significantly, they employ Helen as a housekeeper -- one way for Walcott to illustrate the subservient economic position natives of the island are forced to assume as a result of colonization. Another local figure, Ma Kilman, extends Walcott's analogy between the characters of St. Lucia and those of Homer by assuming the role of an oracle of sorts; she is called a "sibyl," and eventually cures Philoctete of his festering leg wound (58). This healing occurs at the end of the poem and suggests an easing of the wounds caused by imperialism. It asks us to

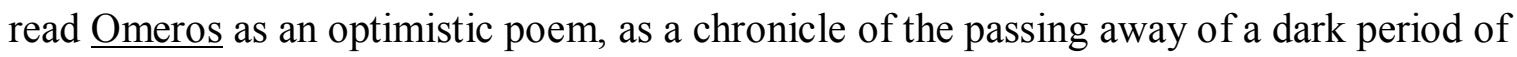
history for the island.

Helen is at the center of Omeros, as she is in Homer's poem. Early in the story, the narrator comments, "Plunkett, in his innocence, / had tried to change History to a metaphor, / in the name of a housemaid; I, in self-defence, / altered her opposite. Yet it was all for her" (270). This statement works as a summation of the respective problems of both Plunkett, the imperialist, and the narrator, the island native. The two characters focus their relationship to history through Helen. For Plunkett she is both an object of desire and pity. For the narrator she is emblematic of the compromised status of the 
islanders. The subordinate position of Helen is made evident in the poem, not only in her role as a maid to the Plunketts, but also in a scene in which she arrives at the Plunketts' house to borrow money. Ultimately she turns away from the money she asks for in defiance. In this gesture Helen indicates she has become cognizant of her subservient status and has repudiated it. The narrator concludes, "[t]here, in her head of ebony, / there was no real need for the historian's / remorse, nor for literature's. Why not see Helen // as the sun saw her, with no Homeric shadow" (271). Like her refusal of the money, the narrator wants Helen to make a break with her past image, to move beyond the "Homeric shadow" which shrouds her, in his view and in ours.

The drawback of Walcott' literary appropriation of Homer's Helen is that it is difficult for the reader to see her without her "Homeric shadow," if only because her name cannot fail to call to mind the famous Helen of Walcott's source text. However, in an attempt to illustrate the difference between the two versions of Helen -- Homer's and his own -- the narrator supplies a useful comparison:

These Helens are different creatures,

one marble, one ebony. One unknots a belt of yellow cotton slowly from her shelving waist, one a cord of purple wool, the other one takes

a bracelet of white cowries from a narrow wrist; one lies in a room with olive-eyed mosaics, another in a beach shack with its straw mattress, 
but each draws an elbow slowly over her face and offers the gift of her sculptured nakedness, parting her mouth. (313)

This gesture of Helen "parting her mouth," an image of wanton sexuality, strikes the reader as peculiar. Surely, one would think Helen would be depicted in a manner beyond the mere vicissitudes of the sexuality by which she has been defined for millennia in European literature. Yet representation is something of a crisis for Walcott: his difficulty comes in attempting to recast the past in a way which allows him, if not wholly to overcome the burden of "history," at least displace it to some degree. Emphasizing the dark skin and impoverished conditions of his Helen seems one way to do this and it forces the reader to reflect on the disparity between the material conditions of the narrator's native island (a "beach shack" with a "straw mat") and the riches of Western empires (a "room of olive-eyed mosaics"). The revealing contrast between the two Helens shows us precisely why Homer's poetics cannot be fully reflective of the narrator's experiences and why The Iliad must be made the subject of Walcott's revisionism. The narrator finds he must utilize materials from his own realm of reference, even as he lifts characters or themes from Homer's famous tale.

As a way to combat the "Homeric shadow," the European influence, that casts itself over the island, the poem's protagonist, Achille, embarks on a search for his origins. Achille thus attempts to move beyond the Western inheritance which is also a sizeable obstacle for the poem's narrator. Achille's origin-seeking comes in the form of a dream journey in which he returns to Africa to recover his ancestral heritage. In his dream 
Achille travels by boat, paralleling the wanderings of Odysseus (and we might recall the metaphor of the narrator's desk as a raft). Despite this promising return to his African source, which had up to this time been unavailable to him, Achille fails to escape the watchful eye of the Christian god of the imperialist. His journey is given official sanction by this god whose very presence prevents Achille from remembering the names of the African deities with whom he feels he must reconnect:

Now the strange, inimical river surrenders its stealth to the sunlight. And a light inside him wakes, skipping centuries, ocean and river, and Time itself.

And God said to Achille, "Look, I giving you permission to come home. Is I send the sea-swift as a pilot, the swift whose wings is the sign of my crucifixion.

And thou shalt have no God should in case you forgot my commandments." And Achille felt the homesick shame and pain of his Africa. His heart and his bare head

were bursting as he tried to remember the name of the river- and the tree-god in which he steered, whose hollow body carried him to the settlement ahead. (134)

The importance of names in this section of the poem ("he tried to remember the name") will recur when Achille speaks with Afolabe, his father; it is precisely this remembrance 
of the old names which the "albino god" disallows (139). The transformation of God's language into a dialect familiar to Achille ("Is I send," etc.) suggests that God dominates the actions of Achille, even as He is figured in Achille's own image. Paula Burnett points out, "it is entirely logical that an individual's interior dialogue with his God would make use of his own language" (142). But we must remember that this is not Achille's god by choice; it is a god who imposes Himself on Achille. There is the sense here, then, that the relationship of Achille to God parallels Walcott's own relationship to Homer which similarly oscillates between dutiful reverence and subversion. Much as Achille must contend with the Christian god, so too must Walcott wrestle with the legacy of Homer. Achille's voyage eventually carries him to Africa, where he meets with his long lost father, Afolabe. The dialogue between the two characters proves the poem's most important meditation on naming and the effectiveness of its medium -- language -- in reflecting perceptions of reality. Afolabe asks his son, "Achille. What does the name mean? I have forgotten the one that I gave you." Achille responds:

Well, I too have forgotten.

Everything was forgotten. You also. I do not know.

The deaf sea has changed around every name that you gave us; trees, men, we yearn for a sound that is missing. (137)

It is significant that the idiom Achille uses here, a more grammatically "correct" register of English, appears nowhere else in his speech in the poem. Only in his dream vision, when he is closest to his unconscious mind, can he express his desire to connect with the origins of his culture, to recover those lost names, that "sound that is missing" which 
could offer some clue as to his source. He hopes to do this in a way less bound by the particulars of his perspective, as represented by his dialect. His experience, in other words, can be taken as universal in the sense that he embodies a search for origins which, as we saw in our introductory chapter, cuts across a number of writers and periods. In any case, Achille's use of "standard" English stands in contrast to the "sub-standard" English utilized in God's exhortation to him.

Afolabe answers Achille's inquiry into names by noting, "[a] name means something. The qualities desired in a son [...] since every name is a blessing, // since I am remembering the hope I had for you as a child. / Unless the sound means nothing. Then you would be nothing. Did they think you were nothing in that other kingdom?" (137). Clearly Afolabe believes in the importance of naming which Achille intimated when struggling with the Christian god. But Achille expresses ambivalence: "I do not know what the name means. It means something / maybe. What's the difference?" he asks (138). Afolabe answers him: "if you're content with not knowing what our names mean, // then I am not Afolabe, your father [...] you, nameless son, are only the ghost // of a name" (138). Afolabe's words are intended to teach his son the importance of remembering the names, of remembering the past. Yet Afolabe also places an emphasis on the signifier which will prove unhelpful to Achille. At the end of the poem, when many of the other characters appear to have attained some degree of self-awareness, Achille still seems stricken with a preoccupation with origins which does him little good. We might trace his anxiety with origin-finding to the suggestion here of Afolabe that Achille could become a function of the signifier, a "ghost of a name," if he does not recognize the importance of naming. Significantly, Achille's name shifts in the last pages 
of the poem from "Achille" to "Achilles" (324). The instability of the signifier used to represent Achille himself suggests the narrator's distrust of Achille's preoccupation with names and the instability of Achille's identity. It also suggests a conflation of Homer's Achilles and Walcott's Achille. Although unlike in most ways, they share a stubbornness that disregards the desires and perspectives of others.

Just as Omeros' interest in self-reflexivity and the epic is anticipated in "Origins," so too is its concern with naming presaged by a short poem entitled "Names" which first appears in Walcott's volume Sea Grapes (1976). Here Walcott offers a vision of an unnamed people, again compared metaphorically with the sea: "[m]y race began as the sea began, / with no nouns, and with no horizon" (Collected Poems 305). This "race" is given names, given a "horizon" and a boundary, by others. Subjectivity appears to be an unwelcome gift to these people: "my race began like the osprey / with that cry, / that terrible vowel, / that I!" (306). As an act of subversion these names are disregarded by the people to whom they are attached: "with nothing in our hands // but this stick / to trace our names on the sand / which the sea erased again, to our indifference" (306). Bhabha has written of this poem, "it signifies the destiny of culture as a site, not simply of subversion and transgression, but one that prefigures a kind of solidarity between ethnicities that meet in the tryst of colonial history" (231). Indeed, Walcott's interest in nomination has less to do with the signifying capacity of words themselves and more to do with the power associated with language as a political tool. We saw this first with God's words to Achille and then again in the exchange between Achille and Afolabe. In both cases language and naming were used as a means for expressing the characters' relationship with origins. 
There is a distinction to be made here, between "imposed" origins, as Homer is to Walcott and the Christian god is to Achille, and what we might call "elected" origins as we find Achille attempting to construct with his return to Africa. Despite the different sources of these origins - whether they come from one's self or from others -- the outcome turns out to be much the same. Achille can establish his own origin story and thereby repudiate the Christian god, but he is ultimately no more empowered when he does so. This is apparent in the final appearance of the theme of naming in Omeros, near the poem's end. After being reunited with Helen after the death of Hector, Achille suggests that they give Helen's unborn child an African name. Ma Kilman tells us, "'Helen don't want no African child. / [Achille] say he'll leave it // till the day of the christening. That Helen must learn / where she from"' (318). Helen is unmoved by Achille's argument and rejects his proposal; through this process she also rejects the origin Achille wishes to evoke. Helen embodies the narrator's argument that there is little to be gained by a return to the origin, whether it is of one's own choosing or not. If Helen agreed with Achille she would be replacing one origin with another. Neither origin offers her a way to move beyond the problems of the past; in fact they both keep her resolutely centered in the past. Hope for the island rests in some middle ground between acknowledging its origins and looking toward its future.

It is perhaps in this way that the poem's admission that "all colonies inherit their empire's sin" makes sense (208). Helen's indifference to her African past is a consequence of her subjection to British sway. On the other hand, Walcott also indicates that the future of the island does not rest with a return to some origin. Ultimately it is within the powers of the inhabitants of the island itself, and not outsiders, to affect the 
changes that bring closure to the poem: Ma Kilman heals the wound of Philoctete, a wound that can be seen as a metaphor for the afflictions of history and empire; Omeros comes to stay on at St. Lucia not as a European figure but as a transformed character who enthusiastically acclimates himself to island life and assumes a speech style akin to Achille's (317); racial divisions are at least partially transcended as Major Plunkett's affinities with Helen are confirmed in a "moment [which] bound him for good to another race" (307). Differences remain, of course: there are still separate "races." But Plunkett has come to value his status as an islander over his place in the old British Empire. The origin for these various characters has been effaced: Plunkett leaves behind his British identity much as Achille is similarly forced to dispense with his African identity by Helen's refusal of his proposal. Origins, whether they are a product of one's birthright (Plunkett), or a matter of one's own selection (Achille), are questioned at the end of the poem.

\section{Omeros as an Epic?}

Despite Philoctete's healing, some wounds stand witness to the effects of history and empire. The poem's narrator, after his meeting with Plunkett, remarks on "the wound of a language I'd no wish to remove" (270). The "language" which is a "wound" is of course English, the idiom that mediates his relationship to Homer. Language can indeed be an affliction, as we saw in Achille's relationship to God as well as in Afolabe's threat that Achille could become a "ghost of a name." Yet language also permits the wounds of the past to be remembered in Omeros by the process of recounting them within the narration. This does not imply, however, that history should be taken at face 
value. In his Noble Prize address, "The Antilles: Fragments of Epic Memory," Walcott argues, "[f]or every poet it is always morning in the world. History a forgotten, insomniac night; History and elemental awe are always our early beginning, because the fate of poetry is to fall in love with the world, in spite of History" (What The Twilight $\underline{\text { Says } 79) . ~ T h i s ~ c u r i o u s ~ m i x t u r e ~ o f ~ a n ~ a w a r e n e s s ~ o f ~ t h e ~ p a s t ~ b u t ~ a l s o ~ a ~ w i l l i n g n e s s ~ t o ~ m o v e ~}$ beyond its tragedies informs many of Walcott's writings, Omeros preeminent among them. Although early in the poem Plunkett can consider "how time could be reworded, / which is the historian's task" in an attempt to render history in his own image, by the end his historiographic impulses have ebbed away as he comes to feel real communion with his fellow islanders (95). The island's conflicts have not been entirely resolved at the close of the poem, despite the symbolic and literal healing of Philoctete's wound, but there is the sense that a new epoch of greater respect and dignity is dawning. This is a moment in which the inhabitants of the island, from Plunkett to Achille, can be united in their love of the island. It is thus "always morning in the world," always a new origin that renders the past origin obsolete.

The poem confirms this notion of moving forward with its ending. Instead of echoing Homer, its last chapter closes with an outright inversion of him. In place of Achille's "rage," the narrator of Walcott's poem declares, "I sang of quiet Achille" (320). "Quiet" is an apt term: throughout the poem Achille is essentially an ineffectual individual, to whom Helen returns only after her loss of Hector. When he does assert himself, in suggesting they give Helen's baby an African name, he is immediately rebuffed. Achille stands as an illustration of the way history and empire have weighed on the islanders; his diffidence reflects his compromised position. This leads us back to the 
question of Omeros' status as an epic. If Achille is to been seen as an epic hero, he is an odd one indeed. His over-valuing of the importance of naming represents a position which clearly offers little opportunity for change. Achille seems more an anti-hero, not only in the sense that he is the antithesis to Homer's character of the same name who is filled with passionate "rage" at the beginning of The Iliad, but also because he fails to acquire the self-awareness which appears to have come to many characters of the poem like Helen and Plunkett.

The audience of Omeros is obviously intended as Caribbean ${ }^{11}$; the narrator remarks, "I sang our wide county, the Caribbean Sea" (320). This fact lends support to the contention that Walcott is working within the confines of the epic tradition in that he adopts a public voice intended for didactic purposes. However, the inversion of Homeric themes and ideals, like the hero, undermines the poem as epic in any conventional sense. Instead I would suggest Walcott should be regarded as using elements of the epic to produce a poem which is of its age politically and stylistically -- it is "hybrid" in the sense Eagleton uses the term to characterize postmodern art (201). Thus when he is asked if Omeros is "the great Caribbean epic," Walcott responds,

I think it would be a terrible irony for the Caribbean, if just for the sake of dignifying a race — of saying: This poem is going to redeem history... It would be a terrible kind of presumption — I think. So, I certainly didn't want to do that. All I wanted to do was to celebrate the diurnal, day-to-day heroism of people who go out and face the

\footnotetext{
${ }^{11}$ For an overview of the issue of Walcott's "literary" nature and how this separates him from Caribbean readers see Hamner's critical discussion in Three Dynamite Authors (9-12). Walcott's address of Omeros to Caribbean readers might be construed as an attempt to engage this audience whom he has been accused of consistently forgetting.
} 
arrogance. Is that destiny? Well, yes, that's admirable. Because such people — fishermen — the ordinary lives that are depicted — they have no idea of expanding power. They think they relate to power they relate to the power of the weather and the power that has been in their past — in history and slavery, and so on.

And that's why I resist so much the idea of this poem as being epic in its undertaking. It has elements of epic. It has widths. It has a variety of subjects, and - I suppose - you can say it has heroes, in a way. But there is not a sort of label outside that says: I will now undertake to - you know — to justify, or condemn, or redeem history. (Sampietro)

Walcott points to the political dimensions of the term "epic" here, and in his admission that he has no interest in "redeem[ing] history" he confirms our suspicion that the poem is intended to stand witness to history. In this process the poem must acknowledge its origins - African and European -- even as it calls them into question with its self-reflexivity. Self-reflexivity, as Linda Hutcheon has said, recurs throughout postmodernist texts and indeed we can recall many postmodern long poems, such as those by Armand Schwerner (The Tablets [1999]), James Merrill (The Changing Light at Sandover [1982]), John Berryman (The Dream Songs [1969]), Edward Dorn (Gunslinger [1975]), and many members of the "Language" School of poets (most importantly Charles Bernstein and Susan Howe) which use this device. The self-qualifying nature of self-reflexivity is certainly more a strategy of the 
postmodern long poem than it is the classical epic. To the extent that he attempts to break away from European-centered thinking, we do Walcott's project a disservice when we hold him stringently to European standards such as the epic. ${ }^{12}$ We might say that the author's relationship with the epic is similar to the island natives' relationship with the British: it is a "configuration of power," to use Said's phrase, which must be usurped to move beyond the Master / Servant binary which colonization forces upon them.

We might summarize, then, by noting that Walcott's poem contains features of the epic, such as its use of a public voice and wide audience, its breadth and episodic narrative. But its employment of postmodern strategies like self-reflexivity and its inversion of the epic hero, Achille, suggest a movement beyond the strictures of the classical epic. There are problems with calling Omeros a "long poem" insofar as the long poem is a largely American form stemming from Whitman, as Thomas Gardner has shown, and in this sense it is a product of a different imperialist power. Yet if we recognize the long poem's lack of genre conventions, we see it is pliable in a way not possible with the epic -- or the lyric for that matter. The eclectic nature of Walcott's poem - its use of a verse form reminiscent of Dante, its appropriation of Homeric themes and characters, its densely-packed narrative style - calls to mind other postmodernist texts, such as Kenneth Koch's Seasons on Earth (1987) and Thomas McGrath's Letter to an Imaginary Friend (1997) which similarly employ elements of the epic to subversive ends. Projects like Walcott's help to expand the boundaries of the relatively recent tradition of the long poem to include those who have been

\footnotetext{
${ }^{12}$ Even a critic as sensitive to Walcott's postcolonial position as Jahan Ramazani insists on calling Omeros a "Caribbean epic" (49). I believe the liabilities of doing so far outweigh the advantages.
} 
historically voice-less; after all, this is what the long poem's early practitioner Whitman wished to do in his "celebration" of women and the culturally disenfranchised. Thus although Walcott's text is unique in many regards, the affinities it shares with many other poems written in the second half of the twentiethcentury help us place it within the context of the postmodern long poem which embraces plurality and alternative points of view at the same time it foregrounds its own form and artifice through strategies like self-reflexivity. In the next chapter we will see how a poet based at the center of the English empire, Geoffrey Hill, similarly questions the hegemonic tendencies of European cultures while also foregrounding the formal elements of his text, including its language and use of anachronism. 


\section{Chapter Four}

Narrating the Origins of the Nation: Geoffrey Hill's Mercian Hymns and "An Apology for the Revival of Christian Architecture in England"

\section{Geoffrey Hill, the Nation, and Anglo-Saxonism}

In chapter one, we surveyed a number of writers who were inspired by AngloSaxon literature and culture. We might recall how Pound argued that "The Seafarer" (which he translated in 1911) and Beowulf were examples of an "indigenous art" which was "an art not newly borrowed" (Literary Essays 34 ). He thus suggested there was something essentially "English" about this literature, which explains to a large degree why he would choose to translate a line in his "Seafarer" as "'mid the English" when it is usually construed as "among the angels." We should recall other figures, more on the periphery of modernism, such as Basil Bunting (Briggflats, 1966) and the Welsh poet and artist David Jones (The Anathemata, 1952) who both posited Anglo-Saxon England as an originary moment. Nicholas Howe points to more recent poets like Thom Gunn and the American Richard Wilbur as others who represent the "afterlife" of Old English Poetry (294). Translations among leading poets in the last century were many, including Scottish poet Edwin Morgan's Beowulf (1952) and his version of the Anglo-Saxon "lyrics" in Dies Irae (1952). Seamus Heaney's Beowulf (2000) continues this tradition. Although drawing on a Middle, rather Old, English text, W.S. Merwin's recent version of Sir Gawain and the Green Knight (2002) is also notable in that it attests to the continuing influence of medieval literature on English-language poets over the course of the last century and into the twenty-first. 
Among these poets stands Geoffrey Hill who most extensively grapples with the problems that arise from trying to connect with historically remote Anglo-Saxon England. In Mercian Hymns (1971) Hill ultimately questions the desire to view the Anglo-Saxon past as the origin of modern Britain as we find in Pound or Bunting. This is a complex struggle because on one hand Hill recognizes the importance of remembering the past; if nothing else, his poem succeeds in drawing our attention back to Anglo-Saxon England and forces us to consider its relevance. On the other hand, the poem seeks to emphasize the disparity between present-day Britain and medieval England. Through the use of linguistic dissonance and the extensive employment of anachronisms, Hill's poem showcases the historical dislocations that result from appropriating an Anglo-Saxon origin. Much of Hill's critique of the impulse to draw on the past to define the present remains well below the surface of his dense work and we have to apply some degree of hermeneutical attention to tease out meaning in Mercian Hymns. Nevertheless, with a careful reading of the poem we find many indications of Hill's dubiousness. Hill's disdain for imperial Britain is evident in another long poem of his from the same period, namely "An Apology for the Revival of Christian Architecture in England" (1978). As Jonathan Bolton points out, in this poem Hill is motivated by a need for "atonement" for British involvement in India. With Mercian Hymns and “An Apology,” Hill presents himself as a writer well aware of the historical grievances that can be leveled against his homeland.

Consisting of thirty short sections which resemble prose poems, Mercian Hymns takes a form reminiscent of Old English poetry as it was written by Anglo-Saxon scribes 
from margin to margin without the lineation of the metrical line we expect today. ${ }^{1}$ Hill's poem evokes eighth-century England, particularly as it is figured through the memorable King Offa (757-96). Offa is well known for his advances in coinage, ${ }^{2}$ defensive works (a dyke along the Welsh border still visible today), and legal codes, if not his contributions to the arts (some speculate that Beowulf ought to be credited to his court ${ }^{3}$ ). He is often celebrated for supplying much needed order to England during his time. ${ }^{4}$ Despite his contributions to the security and prosperity of his homeland of Mercia, Offa was also known for barbarous ways with his enemies, a quality which receives attention in Mercian Hymns. The poem's depiction of the merciless nature of Offa gives us our first suspicion that Hill is up to something different in his poem than his predecessors. After all, if he wished to argue for the Anglo-Saxon origins of his nation why would he choose a rather unlikable ruler for an originary figure whom he depicts as short tempered and intensely paranoid, a character whom he notes is "cushioned on a legend" (Collected Poems 105)? These, surely, are not the characteristics Hill would like to see at the source of his native culture. Attempts to return to the origin typically entail striving to "bring something back" (to use Eliot's phrase) which is desirable, not bringing back the undesirable.

\footnotetext{
${ }^{1}$ Of course one could point to other prose poem traditions, especially that stemming from the French Symbolists. Nevertheless the Anglo-Saxon precedent has been viewed by Hill's critics (Hart 156; Howe 303 ) as the source of his form. Hill himself cites the prose "Mercian Hymns" from Sweet's Anglo-Saxon Reader as the inspiration for his poem (Mercian Hymns np).

${ }^{2}$ Frank Stenton writes, "[t]he continuous history of the English currency begins in Offa's time" (223).

${ }^{3}$ Sam Newton argues, "although positive evidence is still wanting, there are grounds for regarding Beowulf as an eighth-century East Anglian composition" (xi). Along the same lines, Patrick Wormald notes, "Beowulf is undatable, and modern fashion favours a much later date than used to be accepted. But there remains a temptation to fit it into Offa's period, or that of his immediate successors. The poet seems to go out of his way to discuss Offa's illustrious namesake and claimed ancestor, Offa of Angen" (128).

${ }^{4}$ Wormald stresses Offa "was the first Anglo-Saxon king to be called 'king of the English' in reputable charters" (101). Of his international power, Stenton tells us that "[b]etween 784 and 796 Offa was the only ruler in Western Europe who could attempt to deal on equal terms with Charlemagne" (215).
} 
Hill calls on us to examine the figure of Offa in the "Acknowledgments" that he originally published with the poem (this section has been subsequently dropped from the current edition). He is careful to stress the ubiquity of Offa's presence, across the ages:

The historical Offa reigned over Mercia (and the greater part of England south of the Humber) in the years AD 757-796. During early medieval times he was already becoming a creature of legend. The Offa who figures in this sequence might perhaps most usefully be regarded as the presiding genius of the West Midlands, his dominion enduring from the middle of the eighth century until the middle of the twentieth (and possibly beyond). The indication of such a span will, I trust, explain and to some extent justify a number of anachronisms. (Mercian Hymns np)

I want to look into the "anachronisms" Hill speaks of here shortly. For the moment what interests us is the suggestion of Offa's enduring influence, a figure through whom a notion of an essential "Englishness" has been implied by Hill's characterization of him as a "presiding genius of the West Midlands." Yet this is a phrase in which we must detect some irony: what does it say about England if a ruler of such ruthless character is its "presiding genius?" The phrase "his dominion" is also significant because in it we hear the language of tyrannical rule and this gives us a further clue as to Hill's point of view. As Hill indicates in this passage, Mercian Hymns operates as a meditation on the possibility that Offa's influence persists to the present day and "possibly beyond." The logical conclusion to this line of thinking is that if Offa is the originary figure of Britain that which is deplorable in him is also part of its origin. We will recall from chapter one that John B. Vickery speaks of modernism's “elegiac" mood. One way for Hill to 
combat the nostalgia for the past in his predecessors like Eliot and Pound is to emphasize originary thinking's negative side - if Offa is the origin of Britain, he is the origin of its tendencies toward violence and imperialism.

Hill's critics have tended to look at Offa as a representative of the British nation in Mercian Hymns. William Logan contends that he is "a figure whose achievements in coinage and brutal political union continue to preside over notions of Britain as a nationstate." Vincent Sherry concurs: "[t]he historic Offa stands on the edge of the canonical British past, an inceptor in the nascent political life of the nation" (126). Henry Hart argues that Hill's poem is "an indictment [...] of a particularly English inheritance" and emphasizes Hill's role in this "indictment": "Mercian Hymns is a diagnosis of a king and his nation (Offa is the English nation) and Hill is the surgeon [...] to cut open the body, discover the sickness, and administer the cure" $(153 ; 154)$. I want to suggest that Offa stands as a synecdoche for the problems that come with the search for the origins of the nation. ${ }^{5}$ As we have remarked, if Offa is regarded as the origin of the British nation, that origin is ultimately one composed of negative characteristics. This gets at one of the main issues involved in origin-seeking. If one chooses to engage in originary thinking, how does one evaluate the drawbacks that inevitably come with the advantages of positing an origin (the advantage being, apparently, finding prestige for the present in the illustrious past)? Among modernist works this question often goes unanswered but it is a consistent problem for postmodernists. For example, Schwerner's Tablets, as we saw in our introduction, looks into the ramifications of projecting a modern(ist) consciousness onto archaic texts. Similarly, Hill alludes to the search for the origin of the British nation

\footnotetext{
${ }^{5}$ Theorists of nationalism often posit England as the "origin" or first of nations. For an overview of theories of nationalism that start with the emergence of England's nationhood, see Spencer and Wollman, pp. 30-33.
} 
by ironically gesturing to the "long-unlooked-for mansions of our tribe" in Mercian

Hymns (96). And like Schwerner, Hill considers how the past might have been viewed by his literary precursors. Reading Hill's poem against statements like Pound's selfproclaimed search for an "indigenous art" allows us to recognize Hill's response to the search for the origins of a national character evident in many modernist works. ${ }^{6}$

The nation proves, perhaps surprisingly, a relatively recent area of scholarly inquiry. ${ }^{7}$ Perhaps the most frequently cited examination of the nation today is Benedict Anderson's Imagined Communities. As his title implies, Anderson sees the nation as "an imagined political community" which he stresses is "imagined as both inherently limited and sovereign" (6). Anderson calls this an "imagined" community because the people of a nation are dispersed over a wide area and it is only through shared beliefs that they can identify with one another. His theory thus calls for a certain homogeneity of perspective which, as we shall see in a moment, will be scrutinized by others. Anderson says this imagined community is "limited" because there are "finite, if elastic boundaries, beyond which lie other nations" (7). We will observe Hill toying with this notion of the geographical boundaries of the nation in Mercian Hymns. Finally, Anderson stresses the "sovereign" nature of the community because "the concept was born in an age in which Enlightenment and Revolution were destroying the legitimacy of the divinely-ordained, hierarchical dynastic realm" (7). Hill similarly wishes to point out the difference between Offa's kingdom and the British nation. In Anderson's view, the nation is an historically-

\footnotetext{
${ }^{6}$ Aside from Pound and Bunting, one calls to mind especially the cultural nationalism that lies at the heart of work by major Irish figures like W.B. Yeats and Lady Gregory. Their joint project to collect Irish folk tales can be seen as an expression of cultural nationalism, as can be the plays they wrote, such as Gregory's Grania (1910) or Yeats' Cathleen ni Houlihan (1902), for the Irish National Theater.

${ }^{7}$ John Hutchinson and Anthony D. Smith write, "[a]s an ideology and movement, nationalism exerted a strong influence in the American and French Revolutions, yet it did not become the subject of historical inquiry until the middle of the nineteenth century, nor of social scientific analysis until the early twentieth century" (3).
} 
bound concept, one which came into being only with the confluence of two important factors: the advent of advanced capitalism and the establishment of a print culture. He explains that " $[\mathrm{t}]$ he convergence of capitalism and print technology on the fatal diversity of human language created the possibility of a new form of imagined community, which in its basic morphology set the stage for the modern nation" (46).

Homi K. Bhabha has extended and refined Anderson's point of view. He speaks of the "nation as a form of narrative" and, indeed, we can view Hill as producing his own narrative of the British nation. This is a narrative which questions originary thinking by exposing the compromises which result from adopting it, particularly in having to accept the undesirable aspects of the origin (Offa's ruthlessness) with the desirable (Offa's social works). Hill's poem is unique among later twentieth-century long poems in the way it brings consideration of the nation to our attention. As Bhabha points out, constructing the nation and national identity can be viewed as a textual process:

To encounter the nation as it is written displays a temporality of culture and social consciousness more in tune with the partial, overdetermined process by which textual meaning is produced through the articulation of difference in language; more in keeping with the problem of closure which plays enigmatically in the discourse of sign. (Nation and Narration 2)

Bhabha's interest in "textual meaning," "the articulation of difference in language," and "the problem of closure" all point to a poststructuralist perspective on the instability of the signifier which ultimately serves to disrupt the concept of the nation that appears relatively unified in Anderson's paradigm. The instability of the discourse of nation, a discourse upon which the idea of the nation is built, points to a corresponding instability 
in the nation itself. As we shall see, throughout Hill's poem there is a curious mixture of different levels of diction which resists a unified style that would be more felicitous in telling the story of the nation. His distrust of the signifier, in other words, is another reflection of his resistance to the kind of cultural unity that a view of British national origins in Anglo-Saxon England promises.

Elsewhere Bhabha speaks of "the ambivalence of the 'nation' as a narrative strategy" (Location of Culture 140). He continues: "[a]s an apparatus of symbolic power, it produces a continual slippage of categories" (140). It is thus against the relatively homogenous view of Anderson's problematic "imagined community," which assumes a commonality amongst its members, that Bhabha stakes his claim, pointing to the dissenting voices of minorities and other marginalized figures within a nation as a group contrary to the unity of the nation as a single, monolithic entity (158). Certainly Geoffrey Hill, despite an economically humble childhood, cannot be considered a marginalized figure in the same sense Bhabha discusses; in fact given his current, elevated status in the literary world many would consider him firmly planted in the center, not on the margins. ${ }^{8}$ Nevertheless, Hill can write against Anglo-Saxon England as the inevitable national origin of Great Britain. In the manner of the figures Bhabha discusses, Hill offers a narrative of Anglo-Saxon origins filled with "ambivalences" ${ }^{9}$ and "slippages" which allows him to distance himself from his literary precursors.

Hill's postmodern response to the quest for an Anglo-Saxon origin evident in figures like Pound should come as little surprise when we consider the historical situation

\footnotetext{
${ }^{8}$ William Logan, however, points out that Hill "has forced the marginal into our modes of attention, at the risk of seeming bizarre or merely idiosyncratic and therefore a figure of margins himself."

${ }^{9}$ David Perkins sees ambivalence at the heart of Hill's poetry and notes Hill's "lines typically embody an intense, complicated self-conflict, and knot into unresolvable ambivalence" (463).
} 
Allen Frantzen describes in his book A Desire for Origins. Frantzen shows the institutional study of Anglo-Saxonism to be a byproduct of British involvement in the East. Building on the efforts of Edward W. Said (whose work we touched on briefly in the last chapter), Frantzen suggests British Orientalism inspired a search for the origin of some essential "Englishness" to stand in contradistinction to the foreign cultures with whom Britain was in commerce. Frantzen emphasizes "a central characteristic of Orientalism" which he notes is "an acute consciousness of the superiority of Anglo-Saxon heritage without which the stereotypical British view of India would be inconceivable" (28). He argues that "the search for origins is never disinterested; those wishing to trace an idea or tradition to its historical, linguistic, and textual beginnings have always done so with a thesis in mind, and the origin they have found has often been an origin they have produced" (xii). It is precisely this deliberately constructed nature of the origin which we will witness Hill evaluating in Mercian Hymns.

The search for origins among Britain's Anglo-Saxon past, then, can be viewed as contributing to the development of a British national character and ultimately reinforcing a notion of the superiority of the British nation. Frantzen remarks, "[n]ineteenth-century Anglo-Saxonists demonstrated the nationalism that motivated their scholarship; nationalism recalls in many ways the theological and political conditions in which AngloSaxon scholarship began in the Renaissance" (56). Concerning nationalism generally, Ernest Gellner notes, "nationalism is not what it seems, and above all it is not what it seems to itself. The cultures it claims to defend and revive are often its own inventions" (64-65). Gellner's emphasis on the "invented" nature of "cultures" echoes Frantzen's statement that origins are always "produced." Eric Hobsbawm similarly notes, "the 
national phenomenon cannot be adequately investigated without careful attention to the 'invention of tradition'" (14). "Invention" is clearly the operative word for both Gellner and Hobsbawm. The emphasis on "invention" points to the arbitrariness and instability of tradition, how it is fabricated for specific, motivated reasons. What we find when we look into the search for Anglo-Saxon origins, then, is an invention of a tradition, namely Anglo-Saxon England as the origin of the modern British nation, that strengthens the image of the nation projected in contradistinction to the "Oriental" Other. It is against this Other that Frantzen feels early Anglo-Saxon scholars defined themselves.

With the motivated nature of pursuits of tradition and origins in mind, I would now like to look more deeply into Mercian Hymns. Although there would be obvious advantages to dividing up my discussion of the Hymns thematically, I would prefer to work through the poem as it is sequenced. The advantage to this approach is that it allows us to observe the way in which the text progresses, from the invocation of Offa in the first section to his dissolution into thin air in the last, as if his spirit has been exorcised through Hill's "narration.” Hill employs a dissonant diction and playful anachronisms to emphasize the disparity between the (post)modern and the medieval. This is a process which recognizes the "invented" nature of "tradition" and questions a national originary moment. The poem goes far to illustrate how dubious our results can be when we attempt to bring Offa into our own time. I will finish my discussion with a brief overview of "An Apology for the Revival of Christian Architecture in England" which offers a somber view of Britain's status in the world after its long history of cultural and economic hegemony. 


\section{Language and Anachronism in Mercian Hymns}

The very first of the Hymns presents us with one of the anachronisms Hill speaks of in his "Acknowledgement" section. The poem begins auspiciously with an invocation of Offa that proves a strange mélange of the past and present: "King of the perennial holly-groves, the riven sandstone: overlord of the M5: architect of the historic rampart and ditch" its speaker intones (Collected Poems 93). Harold Bloom objects to Hill's assessment of the poem's anachronisms, noting, “[n]othing can be anachronistic when there is no present" (xxiii). I would argue, however, that there is indeed a tangible present in Hill's poem: that of the M5 highway which divides what was once much of Offa's Mercian kingdom. In its second definition for the term, the OED says an anachronism is "[a]nything done or existing out of date; hence, anything which was proper to a former age, but is, or if existed, would be, out of harmony with the present." That which is "out of harmony with the present" here is Offa as "overlord of the M5." Completed in $1977,{ }^{10}$ the M5 links Birmingham and Exeter, in essence running parallel (although to a further degree southward) to the "historic rampart" Offa built on the Welsh border. There is the sense, of course, in which Offa was lord over the region much of the road covers and thus, historically-speaking, he would be its overlord. However, discrepancies in technology make Offa appear unconvincing as the "overlord" of the M5: the modern highway system that webs Britain contrasts strikingly with the nontechnological and archaic (even if effective) dyke Offa built. The historical parallel of the dyke and M5 breaks down on further examination: the M5 is intended to encourage travel; the dyke to inhibit it. Nevertheless, the passage presents Offa as an "architect" of not only the "historic rampart and ditch" which helped determine the Welsh border in

\footnotetext{
${ }^{10}$ A useful description of the M5 can be found at http://euclid.colorado.edu/ rmg/roads/m5.html.
} 
Anglo-Saxon England, but also hints at the way Offa has been depicted as an early "architect" of the later English nation, as Logan and the others suggest.

The anachronism present in the first section of Mercian Hymns is only the first of many that persist throughout the poem. The others will follow this pattern of pulling Offa into the present for the purpose of contrasting his time with our own. The poem's very next section continues this promiscuous mixing of past and present. Here Offa's name is expressed as a "Best-selling brand" (94) which strikes us as ironic, because if anything the name seems exotic and unfamiliar, contrary to what we would expect from a "best-selling brand." The originary nature of Offa's reign is noted in the poem's next sentence: "The starting cry of a race. A name to conjure with" (94). Indeed "Offa" is a name Hill can "conjure with," thereby drawing attention to the Anglo-Saxon King's achievements which are sometimes figured as a "starting cry of a race" of the English people. But clearly this originary moment is also something which can be converted into a modern commodity (rendered as a "best-selling brand"). We thus begin to identify traces of the ambivalence inherent in the poem: even as he questions the desire to view Offa as a source of Englishness, Hill must take into account his own time and his own motivations for doing so (which appear to have something to do with addressing the commercial nature of contemporary life in this second poem of Mercian Hymns). There is something of a doubling of the irony here: not only does Hill appear to critique the desire to generate origins implicit in arguments about the relevance of Anglo-Saxon England, but he must also question his own attempt to write a poem which critiques origins. After all, even if Hill disregards Offa as a "starting cry of a race," he has still been considered as such by virtue of Hill's critique. Ultimately, the use of commercial 
culture in the poem, as with anachronisms, proves a means of promoting the differences between Offa's age and the present era. ${ }^{11}$

As Hart argues, this second hymn contains a series of puns and half-rhymes that make light of Offa's name (162-163). The hymn begins: "A pet-name, a common name. Best-selling brand, curt graffito. A laugh; a cough. A syndicate. A specious gift. Scoffed-at horned phonograph" (94). Hill's notes cite a source which represents "Offa" as a "common name." Hart points to the repetition of sounds here -- "graffito," "laugh," "cough" -- which all mime the sound of "Offa" (163). We might also stress that these terms seek to cast a weak and ineffectual image of Offa: whether being poked fun at ("a laugh"), seen as compromised in health ("a cough"), or made the subject of an illicit inscription ("graffito"), no king would want to be associated with these terms. Hart mentions the other negative words that Offa's name invokes: "offal," "awful," etc. (163). The phrase we have looked at already, "The starting cry of a race," can also be read as pun: what is the starting cry of a race? "They're offa!" This section reflects a concentration on the polysemic nature of language which, like anachronisms, will be a consistently employed motif in the poem. The effect of this consistent word play is to ultimately represent the breakdown in the signifying capacity of the signifier. The continual slippages of language, the by-default medium of the poem, finally renders the poem itself unstable.

Critics have commented on the childlike psyche Hill imbues Offa with (Dodsworth; Sherry). A conflation occurs between the speaker's childhood memories

\footnotetext{
${ }^{11}$ This is the primary way I see Hill differing from Eliot, to whom he is often compared (see Logan, Hart, Dodsworth). Unlike Eliot's (in)famous repudiation of the "Shakespeherian Rag" in The Waste Land (138), Hill is much less worried about the encroachment of commercial culture than he is in the way imagery might persist in it.
} 
and those imagined by Offa. Through this process, the present of the poem's speaker becomes Offa's present. In this way Hill offers an illustration of the manner in which ancient figures are made to inhabit the present, a procedure which casts them in our image (as we saw in Schwerner's poem in chapter one). This conflation is present most notably in section VII which extends a theme of the poem's first section by placing Offa in an automobile, calling to the mind the M5:

Ceolred was his friend and remained so, even after the day of the lost fighter: a biplane, already obsolete and irreplaceable, two inches of heavy snub silver. Ceolred let it spin through a hole in the classroom-floorboards, softly, into the rat-droppings and coins.

After school he lured Ceolred, who was sniggering with fright, down to the old quarries, and flayed him. Then, leaving Ceolred, he journeyed for hours, calm and alone, in his private derelict sandlorry named $\underline{\text { Albion. }}$ (99)

The violent nature of Offa is clearly represented in the second stanza where he "flays" his friend for what seems a rather benign act of losing a toy plane. As with the ironic notion of "Offa" as a best-selling product, the name "Ceolred" stands in sharp contrast to the contemporary scene in which the character is placed. Like Offa, Ceolred was a king of Anglo-Saxon England and thus is a character with a "real" historic basis. ${ }^{12}$ In Ceolred we find another Anglo-Saxon personage placed in a contemporary setting in Mercian

\footnotetext{
${ }^{12}$ Ceolred ruled Mercia from 709 to 716 . He was followed by Aethlbald who ruled for forty-one years and who was then followed by Offa. Of Ceolred, Stenton tells us he was "a dissolute youth, who oppressed monasteries, and according to St. Boniface died insane. He was the last descendant of Penda to rule in Mercia, and his death in 716 ends the first phase of Mercian history" (203).
} 
Hymns to stress the potentially dubious nature of the appropriation of the past. The Anglo-Saxon King Ceolred is transmuted into a boyhood friend who is subject to the whims of a childlike Offa - not an impressive image of either king! If Hill wanted to stress the "kingly" nature of Ceolred he surely would have placed him in a more dignified position than Offa forces him to occupy. The exotic nature of the name "Ceolred" promotes the historical distance between the modern reader and the historical figure who is being evoked so that we finally cannot help but be made more acutely aware of the problems that come with importing the past into the present; we might say a temporal dissonance results from that which is "out of harmony with the present."

After his outbreak of punitive violence, Offa departs in his sandlorry -- its "private" nature accentuates his importance. The name of the sandlorry -- "Albion" gestures to the argument that the historical King Offa's reign helped along the transition of Great Britain from the ancient and mythical "Albion" to the modern nation it is today. ${ }^{13}$ One could also point to "Albion" as something of a poeticism in the history of British literature; one finds it persisting throughout a number of works across the ages. ${ }^{14}$ The sandlorry recalls the automobile imagery present in the first poem. We begin to suspect that for Hill the automobile stands a symbol of false power and freedom in the modern world: it is a machine which Offa can use to flee the scene of his "crime" and thus leave behind the wrecked situation he has created. The other persistent image here,

\footnotetext{
${ }^{13}$ Howe puts this well when he writes, "Albion is a dazzling pun here: an old Latin name for England but also for a now-defunct manufacturer of trucks. In that one word, Hill's themes collide: the violent history of the kingdom, the boy's reveries of power, the fading of English industry (the sandlory is 'derelict') [...] all the immersion in historical and temporal density that is Hill's abiding subject in Mercian Hymns" (302).

${ }^{14}$ One finds it, for instance, in historically canonical works such as "Complaint to His Purse" by Chaucer (line 22); in the Fairie Queene by Edmund Spenser (Second Book, Canto X, line 62); in Shakespeare's Henry V (Act 3, scene 5, line 14) and King Lear (Act 3, Scene 2, line 85); in Don Juan by Lord Byron (Canto 16, line 666); in "On Sitting Down to Read King Lear Once Again" by John Keats (line 9); and "Albion" as a figure in William Blake' personal mythology and as a trope in works like Visions of the Daughters of Albion; the list could go on.
} 
the invocation of Offa's coins, is significant because the coins are now underfoot, among "rat-droppings." As we remarked earlier, Offa's coinage was an important element of his reign and the fact it is represented among detritus such as this suggests that even the achievements of kings are subject to the ravages of time and the natural world. The image acts as yet another reminder of the deep time that separates Offa from us: the only physical evidence left of Offa is a few forgotten and scattered coins. Representative of Mercian Hymns as a whole, this short poem illustrates the compression of time and space evident throughout the text. This compression mimetically gestures to the foreshortening of history which is the potential byproduct of originary thinking.

The next poem in Mercian Hymns reinforces our sense of Offa's violent nature. However, instead of employing the theme of movement introduced by the M5 highway and carried through in the sandlorry imagery, Hill places Offa in a single, static scene. In keeping with our earlier observations about the use of language in Mercian Hymns, we might note how Hill utilizes a diction which is heightened and itself seemingly anachronistic:

The mad are predators. Too often lately they harbour against us. A novel heresy exculpates all maimed souls. Abjure it! I am King of Mercia, and I know.

Threatened by phone-calls at midnight, venomous letters, forewarned I have thwarted their imminent devices.

Today I name them; tomorrow I shall express the new law. I dedicate my 
awakening to this matter. (100)

Here the term "maimed" is used and reminds us of section V where we find the line, "I who was taken to be a king of some kind, a prodigy, a maimed one" (97). We may relate this "maiming" 15 to Hill's biography as Hart does (170). We might also view it as a factor of Hill's worldview. Logan speaks of Hill's vision of a "fallen world," one in which afflictions persist. As this poem demonstrates, Offa's affliction appears to be an intense paranoia which is the result of his political position. Perhaps because of this political position, the last sentence in the poem is ironic: there will be no "awakening." Offa changes in no discernible way through the course of Mercian Hymns and the text closes when he finally "vanishes" at the poem's end (122). Here, in hymn VIII, the modern, mundane reality of a "phone-call" contrasts with the elevated, "poetic" nature of the diction ("forewarned," "thwarted," "imminent devices"). This disjunctive approach to language asks the reader to reflect on the poem's medium and the manner in which it renders Offa's rage. To the extent that the language that Offa uses draws attention to itself we are forced to recognize that language is an unstable medium. We are reminded that Offa is here, and always, a product of text. We might recall Bhabha's intention to "encounter the nation as it is written." As a product of text himself, Offa, in other words, is like the nation: always written, always a textual construction.

\footnotetext{
${ }^{15}$ We might also be reminded of the images of King denigration / degeneration from Rene Girard's Violence and the Sacred (see especially pp. 104-108). Or, to pick a source closer to Hill's own literary heritage, we might recall the image of the wounded king in The Waste Land which Eliot admits he borrows from Jessie Weston's From Ritual to Romance (The Waste Land 147).
} 
Later in Mercian Hymns, in section XVII, automobiles appear again. Since he has already traveled over the geography of England -- over "Albion" in his sandlorry “Albion" -- Offa is now in Europe, apparently on a mission to Rome: ${ }^{16}$

He drove at evening through the hushed Vosges. The car radio, glimmering, received broken utterance from the horizon of storms...

"God's honour --- our bikes touched; he skidded and came off." "Liar." A timid father's protective bellow. Disfigurement of a village king. "Just look at the bugger..."

His maroon GT chanted then overtook. He lavished on the high valley its haleine. (109)

John Needham suggests we read the middle section of this poem as a childhood recollection of Offa -- provided we assume, of course, Offa is a child of the twentiethcentury (83-84). However, we have little reason to doubt Needham's reading and what it demonstrates is how far we must go to confer on Offa a modern interiority to make him seem "contemporary" in his outlook. Hill's diction again proves distracting, this time marked by the word "haleine" which he notes derives from La Chanson de Roland. ${ }^{17}$ The poem's punctuation is an issue here as well: we find nothing more than a set of ellipses

\footnotetext{
${ }^{16}$ Offa had good relations with Pope Hadrian I. Stenton writes, "[e]ven at Rome Offa seemed a real, though inscrutable, force in the international world" (215).

${ }^{17}$ Martin Dodsworth explains the tenuous nature of the associations here: "[t]he incongruous phonetic link between 'GT' and 'chanted,' as though the machine evoked a pilgrim's chorus, is precursor to the greater incongruity present in the link between the entirely unheroic and unpaid-for emotional excess of the 'lavished' and the heroic excess paid for in lives of the Chanson de Roland, the sound of whose horn is evoked in 'haleine' - the link itself being made possible only by the mediation of the phrase "high valleys"' (59).
} 
to indicate a change in scene to the middle stanza. This stanza clearly occupies a different space and time than the two stanzas which frame it. Significantly, Offa has traded his sandlorry for a sports car now, the vehicles apparently working as devices to represent his moods: the sandlorry's slow, methodical movement may have been well coupled to his melancholy after "flaying" his friend Ceolred, but now that childhood memories fly through his mind the sports car appears better matched to his reflective state. The extravagance of the sports car also serves as a symbol of the vanity and power that is evident in Offa's character in his dealing with Ceolred in poem VII and his unnamed enemies of VIII.

Hymn XVIII finds Offa apparently committing the violence he promised earlier in section VIII: "He willed the instruments of violence to break upon meditation. Iron buckles gagged; flesh leaked rennet over them; the men stooped, disentangled the body" (110). After utilizing his "instruments of violence," Offa returns to his car and Hill's play with words minimizes the impact of the violent imagery which the previous passage evoked: "He wiped his lips and hands. He strolled back to the car, with discreet souvenirs for consolation and philosophy. He set in motion the furtherance of his journey. To watch the Tiber foaming out much blood" (110). The playful side of Mercian Hymns that emerges in the word play on Boethius' Consolation of Philosophy ("souvenirs for consolation and philosophy") distracts us from Offa's act of violence by calling on us to regard the flippancy of the pun on the title of Boethius' well known work. ${ }^{18}$ Similarly, there are no such things as "discreet" souvenirs in modern society. Souvenirs are made to be kitschy reminders of a trip or experience; if anything they strive

\footnotetext{
${ }^{18}$ We should recall that there is a connection with Anglo-Saxon England and Boethius: Alfred (King of West Saxons, 871-899) was credited with translating Consolation. Later, Chaucer would also translate it.
} 
to be indiscreet. 19 Offa's "souvenirs" propel us back to the second poem and its emphasis on a "best-selling brand" and the rhetoric of modern commercialism. Mercian

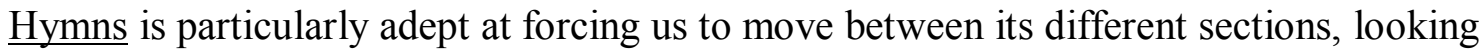
for unities in theme and character. In this way the poem itself is the site of much traversing, textually, as we attempt to extract meaning from the densely-packed hymns. The poem is ultimately against unity, however; whether it is unity of time (as figured in the anachronisms) or unity of discursive style (as in the language we have examined) the poem resists unification.

As in the hymn of Offa's phone-call, the diction in XVIII is humorously elevated in its final two lines: "furtherance" comes from a higher register of speech than the rather common phrase "he set in motion" and we must consider "much blood" in contradistinction to what, a little blood ${ }^{20}$ Hill's speaker is intent on making every situation in which Offa appears finally seem ridiculous: whether his language (or the narrator's, as here) is pedantic and overwrought, or whether the focus is on locomotive imagery which stresses the anachronistic nature of using Offa as a figure of English origins -- Offa as a maker of roads, as riding in his sandlorry after mercilessly handling his friend, as remembering a childhood biking accident while zooming down the highway in his maroon GT, or in returning to his car after another act of senseless violence -Offa's "kingly" nature is only evident in the merciless power he does not hesitate to use. There is something undeniably humorous about placing a medieval king in a modern automobile, a juxtaposition of the past and present that is anything but "harmonious."

\footnotetext{
${ }^{19}$ There is of course the possibility that Hill wants us to think of "souvenir" in another sense: the OED's first definition calls it "[a] remembrance, a memory." Given his earlier invocation of the language of commercialism ("best-selling brand"), however, this reading seems less likely.

${ }^{20}$ As Hill indicates in his notes, "To watch the Tiber foaming out much blood" comes from Virgil.
} 
Moreover, few of the Anglo-Saxon King's entourage seem to have made the time warp with him: aside from the men who help him commit his violence in hymn XVIII, menial tasks, like driving a car, he performs entirely by himself in the poem. This suggests a certain lowered status for Offa when he is brought into our time, an expression of doubt in his importance.

In order to accentuate the disparity between Offa's wealth and power and the reality of more recent British social conditions, particularly in the fallout of the Industrial Revolution, a moving image of poverty is presented near the end of the poem in hymn XXV. XXV depicts the humble scene of a nailer's shop like one Hill's own grandmother labored in. The "I" here thus appears very close to Hill himself. The scene stands in sharp relief to the opulence of Offa, with his henchmen and striking sports car in XVIII. Though one of the longer of the Hymns, it deserves to be quoted at length:

Brooding on the eightieth letter of Fors Clavigera, I speak this in memory of my grandmother, whose childhood and prime womanhood were spent in the nailer's darg.

The nailshop stood back of the cottage, by the fold. It reeked of mineral sweat. Sparks had furred its low roof. In dawn-light the troughed water floated a damson-bloom of dust --

Not to be shaken by posthumous clamour. It is one thing to celebrate the 'quick forge', another to cradle a face hare-lipped by the searing wire. 
Brooding on the eightieth letter of Fors Clavigera, I speak this in memory of my grandmother, whose childhood and prime womanhood were spent in the nailer's darg. (117)

E.M. Knottenbelt points out that Hill's allusion here is to John Ruskin's expansive "Letter to Workmen and Labourers of Great Britain," Fors Clavigera. As Knottenbelt indicates, the "eightieth letter" of the Fors presents an image strikingly similar to the one Hill presents of the speaker's grandmother in this section (186-87). The term "darg"-which Hill glosses in his notes (following the OED) as "“a day's work, the task of a day"'-- comes from Ruskin's description. What Knottenbelt does not mention is that Fors Clavigera begins by expressing a desire to improve the British nation itself. In the second paragraph of his first letter, Ruskin describes Britain as being "afraid of the Russians; afraid of the Prussians; afraid of the Americans; afraid of the Hindoos; afraid of the Chinese; afraid of the Japanese" for the reason that "our only real desire respecting any of these nations has been to get as much out of them as we could" (3). In Ruskin's mind this deplorable foreign policy is reflective of the problem that "we have not courage to defend the right, when we have discerned it" (3). A few pages later, he writes, "I am sure it will be beneficial for the British nation to be lectured upon the merits of Michael Angelo, and the nodes of the Moon. But I should strongly object myself to being lectured on either, while I was hungry and cold" (9). Ruskin's indignation with the current state of the nation proves a useful analogue for Hill who similarly seeks to question the way in which the nation is figured in his reader's imagination. As we shall see, like Ruskin Hill 
will express his regrets for Britain's imperialistic endeavors in “An Apology for the Revival of Christian Architecture in England."

The disparity between the mean working conditions of the workers of the nailer's shop and the excesses of Offa proves the most instructive comparison in the poem. The depiction of the woman spending her "childhood and prime womanhood" in the nailer's shop is antithetical to the image of Offa driving freely in his maroon GT: the dangers of the nailer's trade contrast with Offa's memories of the relatively innocuous bicycle wreck he had as a boy. Hill is careful, however, to resist over-romanticizing "his" grandmother's condition; in fact her labor is rendered in images that stress the harsh reality of her working conditions ("reek of mineral sweat," "face harelipped by searing wire"). Given his recognition of the hardships of the nailer's trade, one cannot say Hill calls for a return to the days of pre-modern cottage industry. If anything, the hard work of the grandmother is intended as a striking contrast with the nonchalance and affluence of King Offa; this contrast is not provided to argue the glories of nineteenth-century Britain over Anglo-Saxon England. Both periods are clearly filled with their own dangers and difficulties. The twentieth-century is marked by problems particular to it as well; after all, its intense need for a connection with the past is the locus of Hill's meditation in the poem.

It might say as much about our habits of reading as it does about the section itself that this hymn is often considered Hill's most successful and affecting (Rosenthal and Gall 300; Needham 81). This surely has much to do with the relative ease with which we read it -- it is markedly less dense than many of the Hymns -- but also because it eschews the ironic anachronisms and disunity characteristic of most of the poems depicting Offa. 
Clearly this section does not need to qualify itself as the others do: its relatively cogent portrait of the speaker's grandmother laboring in the nailer's shop is locked in a specific time and place. It is an image apparently built from living memory and thus its realism frees it from the ironies -- or extravagant diction -- of many sections of the poem centered on Offa alone. The repetition of its stanzas ("Brooding on the eightieth letter...") also helps to give it a greater sense of closure than most of the hymns offer. This repetition suggests the formulaic nature of two poems that survive from the Anglo-Saxon period: "Deor" and "Wulf and Eadwacer." Alluding to Old English verse does not render Hill beholden to the past, mainly because he only wants to hint at its elements by his repetition and use of internal alliteration in the stanzas ("damson-bloom of dust"). This is a step removed from replicating or imitating past poetics, strategies which betray an attempt to return to the origin as we find in the overwrought line "Nathless there knocketh now" in Pound's "Seafarer," to cite only one example (Personae 61).

As Mercian Hymns reaches its end, section XXVIII offers a nearly panoramic view of the past that sweeps over several epochs in England's history. Its first stanza represents the most basic of enduring concerns, the importance of familial ties:

Processes of generation; deeds of settlements. The urge to marry well; wit to invest in the properties of healing-springs. Our children and our children's children, o my masters.

The hymn then widens its perspective:

Tracks of ancient occupation. Frail ironworks rusting in the thorn-thicket. Hearthstones; charred into lullabies. A solitary axe-blow that is the echo of a lost sound. 
Tumult recedes as though into the long rain. Groves of legendary holly; silverdark the ridged gleam. (120)

The section pulls many of the images of earlier hymns back into view. We might note, for instance, the "groves of legendary holly" evoked in this passage that call on us to remember the first section of the poem which named Offa "King of the perennial hollygroves." 21 Thus from prehistoric, pre-Christian time ("groves of legendary holly"), to the Roman era ("ancient occupation"), to the industrial age ("frail ironworks"), within a few lines Hill is able to evoke several major eras in English history. The idea that links these disparate periods is their subjection to the ravages of time, which yields only "tracks" of "ancient occupation." The reader is also reminded of the childhood reveries of the speaker and Offa by the mention of "our children and our children's children." But unlike Offa's foggy memories, the speaker looks forward to the future, not back to the past. This focus on Britain's future generations causes us to look beyond Offa. In fact, at this point in the text Offa has begun to disappear from view: in the penultimate poem we are told "he entered into the last dream of Offa the King" (121).

The process of Offa's dissipation continues. In the final poem "he vanished" into thin air and "left behind coins, for his lodging" (122). Offa's "lodging" occurs as much in Hill's mind as anywhere else. But if Hill is seen as "conjuring" Offa, as the second poem says, he must also dispel Offa's spirit at some point and this comes with emphasizing Offa's proper "lodging" in our imagination. His poem asks us to assess the veracity of viewing Offa as an inadvertent originator of the English nation. Ultimately Hill wants us

${ }^{21}$ The holly-groves are presumably intended to call to mind Celtic England and thus a pre-Offa time. W.S. Milne conjectures that the "holly-grove" here might remind the reader of Sir Gawain and the Green Knight (113). 
to think of Offa as a figure strictly of his own time and motivations. The poem has proven a mediation on the problem of engaging the past in a meaningful way by a singular psyche, one who bears striking resemblances to Hill at times (in particular in the For Clavigera poem). Hill has questioned the assumption that a return to the origin of Englishness will throw light on the present that we find in the statements of his precursors such as Pound and Bunting. We might recall that Hart argues that Hill's poem is "an indictment [...] of a particularly English inheritance" (153). This is certainly true insofar as we see Hill's literary precursors serving as representatives of this "English inheritance." I would suggest that Hill's solution to the problem of literary origins is to take the work of Pound and Bunting to its logical extreme and show us how doubtful the results can be when we concern ourselves too much with defining the present by the past, by focusing too intently on what has been lost (in Vickery's sense of modernism's elegiac mood). Hill's findings are not unlike Schwerner's in that we are offered an illustration of the effect of the modern mind projected onto a figure of the distant past. Like Schwerner, Hill uses textual play to draw attention to this process of "modernizing" the historically distant figure.

Yet we must not lose sight of the ambivalence at the heart of the poem. Offa should remain "lodged" in the mind, Hill implies, not necessarily as an origin of the modern British state, but instead as a figure of history whose presence is felt through an eroding dyke and some extant coins. Hill suggests that we should recognize the past, be cognizant of Offa's presence in British history, but the dangers of seeing him -- and the Anglo-Saxon period - as the singular "origin" of modern Britain should be considered. I would now like to look briefly at Hill's poem "An Apology for the Revival of Christian 
Architecture in England" as a means of concluding. This poem provides a contrast with Mercian Hymns' ambivalence toward history. While "An Apology" is similar to Mercian Hymns in that it is dense and allusive, it nevertheless offers a clear condemnation of British imperialistic practices around the world.

\section{Conclusion: "An Apology for the Revival of Christian Architecture in England"}

Originally published in the volume following Mercian Hymns (Tenebrae [1978]), “An Apology" dramatizes "the conflict between commercial and national interests," as Jonathan Bolton writes. Comprised of thirteen sonnets, at its heart rests a series of sections subtitled “A Short History of British India.” Here Hill takes a penetrating look at England's involvement in the East. Thus looking abroad where Mercian Hymns was concerned with domestic issues, the inspiration for "An Apology" appears to have been Hill's own trip to India. The speaker of its fifth sonnet asks: "Suppose they sweltered here three thousand years patient for our destruction." He ironically continues,

Destiny is the great thing, true lord of annexation and arrears.

Our law-books overrule the emperors.

The mango is the bride-bed of light. Spring jostles the flame-tree. But new mandates bring new images of faith, good subahdars!

Lugging the earth, the oxen bow their heads. The alien conscience of our days is lost 
among the ruins and on endless roads. (144)

The "good subahdars" Hill mentions here are named in the next poem: "Malcolm and Frere, Colebrooke and Elphinstone" (145). Though apparently well-intentioned, ${ }^{22}$ these men nevertheless represent the intrusion of an "alien conscience" that marks the cultural and economic infiltration of England into India. Bolton notes that the poem is "a plea for forgiveness" for this intrusion, and points to Hill's belief that "poetry can serve as an act of penitence." Indeed the irony which is such an important aspect of the poem - evident in the haughty "law-books" that "over-rule" the local rulers; that "they" waited patiently for "three thousand years"; that "destiny" of the kind that brought England into India is a "great thing," etc. -- leaves us with little doubt where the speaker stands on cultural and political imperialism. As with Mercian Hymns, the speaker of "An Apology" feels it is the function of poetry to stand witness to, and comment on, public history in this way. If he cannot repair history, he can at least memorialize it so it is not forgotten. The function of "An Apology" is thus quite different from Mercian Hymns: not to question the origin of the nation but rather to recall one of its more unconscionable historic moments.

Later in the sequence, the speaker's reflections on British-occupied India force him to take stock of the British nation itself:

Platonic England, house of solitudes, rests in its laurels and its injured stone, replete with complex fortunes that are gone, beset by dynasties of moods and clouds.

\footnotetext{
${ }^{22}$ Bolton notes, "however misguided, [they] worked to improve the education, agriculture, and health conditions and attempted to codify laws in accordance with Indian customs and religious doctrine."
} 
It stands, as though at ease with its own world,

the mannerly extortions, languid praise,

all that devotion long since bought and sold[.] (148)

Here we find "Platonic England",23 bereft of its acquired provinces, a "house of solitudes" where the "complex fortunes [...] are gone," where integrity itself appears to have been up for sale ("devotion [...] bought and sold"). Yet England somehow finds itself "at ease with its own world," seemingly unable or unwilling to recognize its impoverished image. It is important to note that the "world" invoked is its "own," not "the" world, and this suggests a certain preoccupation with the self which Hill implies is a factor of British national identity - a self-centeredness we saw quite readily with King Offa and which Ruskin also intimated in Britain's dealings with other countries in the first letter of Fors Clavigera. Hill is speaking from a sense of indignation and bewilderment, taking the only action he can in standing witness to Britain's historical injustices. In this pose he reminds us more of Irish writers like Ciaran Carson and Seamus Heaney than he does of British poets such as Bunting and Jones who were not motivated to write a poetry of political engagement.

In the poem's thirteenth and final sonnet, Hill incorporates religious imagery of a kind which is prevalent in much of his writing. ${ }^{24}$ Here images of the natural world are mixed with a commentary on the diminished status of England, beginning with a first line which is tersely ironical:

So to celebrate that kingdom: it grows greener in winter, essence of the year;

\footnotetext{
${ }^{23}$ The phrase comes from the epigraph from Coleridge with which Hill begins his poem.

${ }^{24}$ Religious imagery and themes are especially prevalent in Hill's first book, For the Unfallen (1959), but persist up to one of his most recent publications, Speech! Speech! (2000).
} 
the apple-branches musty with green fur.

In the viridian darkness of its yews

it is an enclave of perpetual vows

broken in time. Its truth shows disrepair,

disfigured shrines, their stones of gossamer,

In grange and cottage girls rise from their beds

by candlelight and mend their ruined braids.

Touched by the cry of the iconoclast,

how the rose-window blossoms with the sun! (152)

As we can see, the idea that Britain stands "as though at ease with its own world" from sonnet 9 controls "An Apology" up to its final lines. Logan's metaphor of Hill's "fallen world" is clearly present, a fallen world in which "truth shows disrepair" and "disfigured shrines" persist. This scene seems to sum up Hill's view of modern England: it is a nation marred by its impulse to colonize, tarnished even in the eyes of its own inhabitants. Its only hope, it would seem, is to somehow transcend its troubled past. The poem's final image, presumably an icon-breaker of Henry VIII's reign poised to smash the image of England's past (the rose-window), recalls the violence inherent in England's own history.

If Britain is projected as an "imagined community" as Anderson says, Hill sees it as his duty to be a dissenting voice in the community and disrupt the homogeneous 
worldview suggested by Anderson's paradigm. The "cottage girls" who "rise from their beds / by candlelight and mend their ruined braids" offer a depiction of the common people of England awakening to do the work that must be done, despite England's historic misjudgments. Like the grandmother of Mercian Hymns' Fors Clavigera section, it is notably the cottage dweller, the economically downtrodden, who emerge as a source of inspiration for Hill -- not the King, not the "good" subhadars. In the manner Bhabha describes, Hill "narrates" the British nation, clearly questioning its validity insofar as he feels the people of England (and elsewhere) have been made the victims of its machinations. Yet there is an underlying hope that persists. The image of the sun coming through the rose-window at "An Apology's" close indicates that the sun can still rise on Britain -- even if it did finally set on the British Empire.

Knottenbelt points out the similar missions of Mercian Hymns and "An Apology":

[the sonnets of "An Apology"] are not so much a reaction or qualification as a complement to [the] Hymns. There Hill's concern had been with his more personal roots; here, with an attempt to define his sense of poetry as a witness to his roots as an English poet. Both point towards and name origins, and show how he is marked by his past. (247)

I would disagree with Knottenbelt's assessment that Hill's poem is about his "personal roots." As I have hoped to show, Hill is concerned with larger issues of the culture-wide appropriation of past historical moments as "origins"; he uses the personal only as a way to get at the public, and the poems are only vaguely personal. However, I am in perfect agreement with Knottenbelt's belief that "both [poems] point towards and name origins." 
The poems do in fact appear to be "complementary": where Mercian Hymns shows us the results of not being mindful of our distance from the past, "An Apology" is a call for recognizing the oversights of the past but also moving beyond them. Hill's work has continued to be a poetry with political motivations, although it has grown more recondite with a more rarified sense of humor in recent volumes such as Speech! Speech! (2000) and The Orchards of Syon (2002). Nevertheless, Hill is committed to producing a poetry which, while not necessarily being easily accessible, insists on an engagement with its cultural context. This is a poetry that throws light on our shared dilemma of how to use the past in a way which pays homage to important figures and periods but also refuses to elevate them to originary status. If Hill finally rejects originary thinking it is to free Britain to embrace its future and move beyond the grip of its past, to place its fate in the hands of "[o]ur children and our children's children." 


\section{Chapter Five}

\section{Conclusion}

The three long poems I have analyzed by Judy Grahn, Derek Walcott, and Geoffrey Hill each examine the past's continuity with the present as it is figured through originary thinking. These writers adopt different points of view on this issue, however. For Grahn, considering one's origins entails rethinking the function of myth in presentday society. Her method differs from the modernists who preceded her in her embrace of popular culture -- a clear indicator of her postmodernity. Walcott considers how his postcolonial position mediates his relationship to Homer. Walcott uses motifs (such as the voyage as a metaphor for self-discovery) and characters (Helen, Achilles, etc.) that first appear in Homer. To qualify his borrowings, he employs a distinctive selfreflexivity. In Hill we witness a contemporary poet thinking over his relation to history and ultimately rejecting Britain's Anglo-Saxon period as the definitive origin of the modern British nation. This is a process which questions the very relevance of originary thinking.

Each of these writers utilizes some device common to postmodern literature: popular culture and play in Grahn, self-reflexivity in Walcott, anachronism in Hill. Each focuses his or her examination of origins through solitary figures: Grahn with a composite Helen, Walcott through a transformed Homer as Omeros, Hill in the form of the Anglo-Saxon King Offa. This is reminiscent of the epic's focus on a single figure, even if there is the twist here that Helen, Omeros, and Offa are not the heroic characters we find in the classical epic such as Odysseus or Achilles. Grahn, Walcott, and Hill each reevaluate themes and concerns central to writers from the first half of the century. 
Grahn appropriates and transmutes the myth-obsession of modernism. Walcott filters the epic tradition revived by figures like Pound and Olson through his Caribbean consciousness. Hill responds to modernist enthusiasm for Anglo-Saxonism. A poststructuralist distrust in the signifier and skepticism about origins is carried through in each of these writers as well. All of this is to say that family resemblances persist among these otherwise strikingly disparate poets.

Although Mercian Hymns (1971), The Queen of Wands (1982), and Omeros (1990) cover the last three decades of the twentieth-century and thus sit comfortably not only within the conceptual but also within the historical framework of postmodernism, we should nevertheless also emphasize the differences in their poets' perspectives. These writers were selected for their differing national origins (Grahn an American, Walcott from St. Lucia, Hill a native-born Englishman), and their differences in race (Walcott with a "mixed" ancestry) and sexual orientation (Grahn as a lesbian). Of course these three writers do not represent all of the identities or political positions currently available in postmodernism, but they at least gesture to the breadth of diversity which postmodernity embraces in its insistence on plurality. They also hint at the host of writers who have used the long poem as a tool for an inquiry into the past in the latter half of the twentieth-century. Postmodern long poems often posit alternative histories neglected by the white, male-centered poetics of mainstream modernism, as we saw in Grahn's and Walcott's revisionary poems.

Grahn, Walcott, and Hill contrast in their approaches to originary thinking as well. Because of her desire to promote a view of culture (and literature) based around women, Grahn feels she must fabricate the origin herself; she thus rejects the historical 
and patriarchal view of the source of Western culture and literature in Homeric Greece. Walcott is more ambivalent about Homer as a literary origin. He grapples with the ancient poet's influence on postcolonial culture throughout Omeros. He ultimately shows Homer can be made relevant only by being rendered in the image of a native islander and thereby incorporated into St. Lucia's way of life. Geoffrey Hill decides it is his duty to question originary thinking by pointing out the historical dislocations that result from trying to peer into the past to identify the source of the present. King Offa finally appears ridiculous in Mercian Hymns because his point of view belongs to another age.

These poets thus differ in their evaluation of the function of originary thinking in present-day society. Hill abandons the search for origins altogether. Grahn, on the other hand, finds use for it, albeit in a form modified from what she finds among the male modernists who came before her. Walcott, perhaps, falls somewhere in between Grahn's reworking of originary thinking and Hill's repudiation of it. Walcott illustrates how Achille's search for his African roots in Omeros fails to make good on the promise of individuation, even though Achille's journey represents a movement beyond the slavish obedience the colonizer's god seeks to enforce in him.

Despite the fact that these three writers bear out my premise that postmodernists have taken up the search for origins initiated by modernist writers and consistently altered it, they also indicate that origins are still a considerable problem in postmodernity. Recognizing this fact has consequences for the way we read modernism and postmodernism. While I would not suggest we completely jettison the categories -indeed I believe they hold heuristic value and thus I have used them here -- we should recognize that there is a greater fluidity between the periods than is typically admitted. 
The persistence of origins in twentieth-century poetry suggests there is a difference of degree, not kind, in the literary movements that literary historians divide from one another by World War II. Given our own position at the outset of the twentieth-firstcentury, we are beginning to gain the historical perspective necessary to look at the literature of the last century as a whole. As this study demonstrates, considering how writers respond to themes like origins allows us to identify the ways in which postmodernism responds to modernism.

We clearly gain a broader view of twentieth-century poetry from this process of reevaluating the assumed modernism / postmodernism divide. I want to be careful of minimizing the differences between the two periods, however. For instance, I would maintain that they are antithetical in their relations to social equality. Modernism is generally elitist in orientation. Postmodernism, on the other hand, is more democratic and inclusive by nature. Their approaches and general ethos are also contrastive. Modernism is typically difficult and serious; postmodernism is less densely allusive and more interested in play. However, if the theme of origins is any indication, they engage some of the same cultural problems. Striking a balance between promoting difference and recognizing similarity in modernism and postmodernism is no doubt a difficult endeavor. Yet for all its challenges this is a balance we should strive to maintain in our critical views so that we can recognize the dialectic of continuity and change that marks the twentieth-century's literary practices.

We might also consider the effect studying originary poems has on our understanding of manifestations of the nation as they appear in twentieth-century poetry. Chapter four focused exclusively on Geoffrey Hill's struggle with the nationalist 
impulses that become apparent when the origin of Britain is identified as Anglo-Saxon. Derek Walcott's work also engages issues of national identity. As a native of St. Lucia, Walcott speaks from a site of past European imperial activities, and he thus represents a figure outside of the American and British literary traditions that typically are considered in studies of the long poem. Walcott seeks to represent the aftereffects of empire by using characters of his own invention as well as those he inherits from the classical epic. The goodwill expressed between his characters at his poem's end suggests that the island will be unified in a manner that gestures toward nationhood. However, this is not a nation with the imperialistic motivations common to those foreign powers that long sought to occupy St. Lucia - namely, England and France. In contrast to Walcott's marginal status, Geoffrey Hill speaks from a position resolutely at the center of the old English empire. As we have seen, however, Hill acknowledges the historical grievances which are leveled at his homeland. He is just as critical of England's past as Walcott is, registering his contempt for British imperialistic endeavors in India in "An Apology for the Revival of Christian Architecture in England."

The other poet I have examined, Judy Grahn, does not focus on the nation. For Grahn, gender issues supercede concerns with nationalism. In fact her poem is resolute in overlooking local differences like national boundaries in its mission to depict the subjugation of women that has marked Western culture for millennia. Her Helen is a combination of a number of mythological figures culled from different story-telling traditions and is informed by contemporary feminism. Grahn is thus concerned with the global where Walcott is focused on St. Lucia as a microcosm for postcolonial struggle. Walcott is similar to Grahn, however, in that he offers women a prominent place in his 
poem through his use of figures such as Helen and Maud. By comparison, women occupy relatively little space in Hill's Mercian Hymns. ${ }^{1}$ Conversely, we might recall the imagery from "An Apology" in which "[i]n grange and cottage girls rise from their beds // by candlelight and mend their ruined braids." This image suggests a renewal of English culture after many centuries of decay with women taking an important role in this change. Nevertheless, these are hardly individuated women in the sense that Grahn's Helen is at the close of The Queen of Swords and that Walcott's Helen is at least on her way to becoming, if she has not become so already, at Omeros' end.

Thinking about origins thus allows us to consider a number of side issues, such as nationalism and gender equality, in a context which also permits us to look at the poetic output of the last century as a whole. We have seen how poets with styles and social agendas as diverse as T.S. Eliot, Ezra Pound, H.D., Armand Schwerner, Basil Bunting, Louise Glück, Christopher Logue, and Seamus Heaney all engage in a search for, or examination of, origins. Originary thinking clearly holds a pervasive influence over twentieth-century poetry. Whether or not origins will factor into the next age's response to twentieth-century poetics' obsession with the present's continuity with the past will remain to be seen. It is possible that the search for origins will end with the century that devoted so much time and effort to its consideration. Such a possibility seems unlikely, however, since origin-seeking appears fundamental to the human desire to know and understand the past. The fact that this desire has been scrutinized by postmodernists such as Schwerner and Hill, as I have said, should be regarded as proof of its persistence as a

\footnotetext{
${ }^{1}$ The only mention of women comes in Hymn XXI which notes " $[\mathrm{t}]$ he young women wept and surrendered" as Offa's "province" is "fanfared" by "[c]ohorts of charabancs" (113) and the "[t]roll-wives, groaners in sweetness, tooth-bewitchers" of Hymn XXVI. The world of Mercian Hymns is clearly a man's world in which women appear only en masse.
} 
concern for poets rather than evidence that interest in origins is waning. Even if poets are deeply questioning origins, they are still talking about them. We will see if this dialogue persists into the next generation of poets. 


\section{Works Cited}

Altieri, Charles. "Motives in Metaphor: John Ashbery and the Modernist Long Poem." Genre 11.4 (Winter 1978): 653-87.

Anderson, Benedict. Imagined Communities: Reflections on the Origin and Spread of Nationalism. Revised Ed. New York: Verso, 1991.

Appiah, Kwame Anthony. "The Postcolonial and the Postmodern." Ashcroft et al 119124.

Ashcroft, Bill, Gareth Griffiths, and Helen Tiffin. The Post-Colonial Studies Reader. New York: Routledge, 1995.

Baker, Deborah. In Extremis: The Life of Laura Riding. New York: Grove P, 1993.

Baker, Peter. Obdurate Brilliance: Exteriority and the Modern Long Poem. Gainesville: U of Florida P, 1991.

Beach, Christopher. "Migrating Voices in the Poetry of Edward Dorn." Contemporary Literature 32 (Summer 1991): 211-228.

Bernstein, Michael André. The Tale of the Tribe: Ezra Pound and the Modern Verse Epic. Princeton: Princeton UP, 1980.

Berryman, John. The Dream Songs. New York: Noonday, 1969.

Bhabha, Homi K. The Location of Culture. New York: Routledge, 1994.

---, ed. Nation and Narration. New York: Routledge, 1990.

Bloom, Harold. Introduction. Somewhere is Such a Kingdom: Poems 1952-1971 by Geoffrey Hill. Boston: Houghton Mifflin, 1975. xiii-xxv.

Bolton, Jonathan. "Empire and Atonement: Geoffrey Hill's 'An Apology for the Revival 
of Christian Architecture in England."' Contemporary Literature 38.2 (Summer 1997): Academic Search Elite. 9 June 2003. <www.library.proxy.wvu.edu>. Bunting, Basil. The Complete Poems. Ed. Richard Caddel. New York: Oxford UP, 1994.

Burnett, Paula. Derek Walcott: Politics and Poetics. Gainesville: UP of Florida, 2000. Butler, Judith. "Imitation and Gender Subordination." Literary Theory: An Anthology. Eds. Julie Rivkin and Michael Ryan. Malden, MA.: Blackwell, 1998. 722-730.

Caddel, Richard and Peter Quartermain, eds. Other: British and Irish Poetry Since 1970. Hanover: Wesleyan UP, 1999.

Case, Sue-Ellen. "Judy Grahn's Gynopoetics: The Queen of Swords." Studies in the Literary Imagination 21.2 (Fall 1988): 47-67.

Clark, Tom. Charles Olson: The Allegory of a Poet's Life. New York: W.W. Norton, 1991.

Conte, Joseph. Unending Design: The Forms of Postmodern Poetry. Ithaca: Cornell UP, 1991.

De Man, Paul. Blindness and Insight: Essays in the Rhetoric of Contemporary Criticism. 2nd Ed. Minneapolis: U of Minnesota P, 1983.

Dehler, Johanna. Fragments of Desire: Sapphic Fictions in Works by H.D., Judy Grahn, and Monique Wittig. New York: Peter Lang, 1999.

---. "Lesbos Revisited: Judy Grahn's The Queen of Swords as Sapphic Mythmaking." Women, Creators of Culture. Ed. Ekaterini Georgoudaki. Thessaloniki, Greece: Hellenic Association of American Studies, 1997. 205-216. Derrida, Jacques. A Derrida Reader. Ed. Peggy Kamuf. New York: Columbia UP, 
1991.

Dickie, Margaret. On the Modernist Long Poem. Iowa City: Iowa, 1986.

Dodsworth, Martin. "Mercian Hymns: Offa, Charlemagne and Geoffrey Hill." Geoffrey Hill: Essays on His Work. Ed. Peter Robinson. Philadelphia: Open UP, 1985. 49-61.

D[oolittle], H[ilda]. Helen in Egypt. New York: New Directions, 1961.

Eagleton, Terry. The Illusions of Postmodernism. Oxford: Blackwell, 1996.

---. Literary Theory: An Introduction. 2nd Ed. Minneapolis: U of Minnesota P, 1996.

Eliot, T.S. Selected Prose. Ed. Frank Kermode. New York: Harvest, 1975.

---. The Uses of Poetry and the Uses of Criticism: Studies in the Relation of Criticism to Poetry in England. Cambridge: Harvard UP, 1964.

---. The Waste Land: A Facsimile and Transcript of The Original Drafts Including the Annotations of Ezra Pound. Ed. Valerie Eliot. New York: Harvest, 1971.

Fletcher, Angus. Allegory: the Theory of a Symbolic Mode. Ithaca: Cornell UP, 1964. Frantzen, Allen J. Desire for Origins: New Language, Old English, and Teaching the Tradition. New Brunswick: Rutgers UP, 1990.

Friedman, Susan Stanford. "When a 'Long' Poem is a 'Big' Poem: Self-Authorizing Strategies in Women's Twentieth-Century 'Long Poems.” LIT 2 (1990): 9-25.

Gardner, Thomas. Discovering Ourselves in Whitman: The Contemporary American Long Poem. Urbana: U of Illinois P, 1989.

Gellner, Ernest. "Nationalism and High Cultures." Hutchinson and Smith 63-69. Glück, Louise. Meadowlands. Hopewell, NJ: Ecco, 1996. 
Grahn, Judy. Blood, Bread, and Roses: How Menstruation Created the World. Boston: Beacon P, 1993.

---. Foreword. Inanna, Lady of Largest Heart: Poems of the Sumerian High Priestess, Enheduanna. By Betty De Shong Meador. Austin: U of Texas P, 2000. xi-xvi.

---. The Highest Apple: Sappho and the Lesbian Poetic Tradition. San Francisco: Spinsters Ink, 1985.

---. The Queen of Swords. Boston: Beacon P, 1987.

---. The Queen of Wands. Trumansburg, NY: The Crossing P, 1982.

---. The Work of a Common Woman: The Collected Poetry of Judy Grahn, 1964-1977. New York: St. Martin’s P, 1978.

Graves, Robert. The White Goddess: A Historical Grammar of Poetic Myth. New York: Noonday, 1966.

Hamner, Robert D. Epic of the Dispossessed: Derek Walcott's “Omeros." Columbia: U of Missouri P, 1997.

---. "Introduction to Critical Perspectives on Derek Walcott." Three Dynamite Writers: Derek Walcott, Naguib Mahfouz, Wole Soyinka. Ed. Donald E. Herdeck. Colorado Springs: Three Continents P, 1995. 3-20.

Hardwick, Lorna. "Reception as Simile: The Poetics of Reversal in Homer and Derek Walcott." International Journal of the Classical Tradition 3.3 (Winter 1997): Academic Search Elite. 28 March 2003. <www.library.proxy.wvu.edu>. Hart, Henry. The Poetry of Geoffrey Hill. Carbondale: Southern Illinois UP, 1986. Heaney, Seamus. Beowulf: A New Verse Translation. New York: W.W. Norton, 2000. ---. Poems: 1965-1975. New York: Noonday, 1988. 
Heidegger, Martin. Poetry, Language, Thought. Trans. Albert Hofstadter. New York: Perennial, 1971.

Henneberg, Sylvia B. "When Helen Awakens: Revisionary Myth in Judy Grahn's The Queen of Wands." Women's Studies 29.3 (June 2000): EbscoHost. 16 July 2003. <www.library.proxy.wvu.edu>.

Hill, Geoffrey. Mercian Hymns. London: Andre Deutsch, 1971.

---. New and Collected Poems: 1952-1992. New York: Houghton Mifflin, 1994.

Hobsbawm, Eric and Terence Ranger, eds. The Invention of Tradition. New York: Cambridge UP, 1983.

Homer. The Iliad. Trans. Robert Fagles. New York: Penguin, 1990.

Howe, Nicholas. "Praise and Lament: The Afterlife of Old English Poetry in Auden, Hill, and Gunn." Words and Works: Studies in Medieval English Language and Literature in Honour of Fred C. Robinson. Eds. Peter S. Baker and Nicholas Howe. Buffalo: U of Toronto P, 1998. 293-310.

Hutcheon, Linda. "Circling the Downspout of Empire." Ashcroft et al 130-135.

---. A Poetics of Postmodernism: History, Theory, Fiction. New York: Routledge, 1988.

Hutchinson, John and Anthony D. Smith, eds. Nationalism. Oxford: Oxford UP, 1994. Hutton, Ronald. The Triumph of the Moon: A History of Modern Pagan Witcheraft. New York: Oxford UP, 1999.

Huyssen, Andreas. After the Great Divide: Modernism, Mass Culture, Postmodernism. Bloomington: Indiana UP, 1986. 
Jameson, Fredric. Postmodernism; or, The Cultural Logic of Late Capitalism. Durham: Duke UP, 1991.

Jones, David. The Anathemata: Fragments of an Attempted Writing. Boston: Faber and Faber, 1952.

Keller, Lynn. Forms of Expansion: Recent Long Poems by Women. Chicago: U of Chicago P, 1997.

Kenner, Hugh. The Pound Era. Berkeley: U of California P, 1973.

Knottenbelt, E.M. Passionate Intelligence: The Poetry of Geoffrey Hill. Atlanta: Rodopi, 1990.

Lehman, David. The Last Avant-Garde: The Making of the New York School of Poets. New York: Anchor Books, 1999.

Locke, Charles. "Derek Walcott's Omeros: Echoes from a White-throated Vase" Massachusetts Review 40.1 (Spring 2000): Academic Search Elite. 28 March 2003. <www.libraries.wvu.edu>.

Logan, William. "The Fallen World of Geoffrey Hill." New Criterion 12.7 (March 1994): Academic Search Elite. 9 June 2003. <www.library.proxy.wvu.edu.> Logue, Christopher. War Music: An Account of Books 1-4 and 16-19 of Homer's “Iliad." New York: Noonday, 1997.

Maier, John. Gilgamesh: A Reader. Wacuonda, IL: Bolchazy-Caduci Publishers, 1997.

Manganaro, Marc. “'Beating a Drum in a Jungle': T.S. Eliot on the Artist as 'Primitive."' Modern Language Quarterly 47.4 (December 1986): 393-421.

---. Myth, Rhetoric, and the Voice of Authority: A Critique of Frazer, 
Eliot, Frye, and Campbell. New Haven: Yale UP, 1992.

McClure, Charlotte S. "'Helen of the 'West Indies': History or Poetry of a Caribbean Realm." Studies in the Literary Imagination 26 (Fall 1993); Academic Search Elite. 28 March 2003. <www.library.proxy.wvu.edu>.

Milne, W.S. An Introduction to Geoffrey Hill. London: Bellew, 1998.

Montefiore, Jan. ““What Words Say’: Three Women Poets Reading H.D.” Agenda 25.3-4 (Autumn / Winter 1988): 172-190.

Moretti, Franco. Modern Epic: The World System from Goethe to García Márquez. New York: Verso, 1996.

Nagy, Gregory. Poetry as Performance: Homer and Beyond. New York: Cambridge UP, 1996.

Newton, Sam. The Origins of Beowulf and the Pre-Viking Kingdom of East Anglia. Cambridge: D.S. Brewer, 1993.

Olson, Charles. The Collected Poems, Excluding the "Maximus" Poems. Ed. George F. Butterick. Berkeley: U of California P, 1987.

---. Collected Prose. Ed. Donald Allen and Benjamin Friedlander. Berkeley: U of California P, 1997.

---. The Maximus Poems. Ed. George F. Butterick. Berkeley: U of California P, 1983.

---. Selected Writings. Ed. Robert Creeley. New York: New Directions, 1966.

Paz, Octavio. The Other Voice: Essays on Modern Poetry. New York: Harcourt Brace Jovanovich, 1991.

Pearce, Roy Harvey. The Continuity of American Poetry. Princeton: Princeton UP, 1961. 
Perkins, David. A History of Modern Poetry: Modernism and After. Cambridge: Belknap P, 1987.

Perloff, Marjorie. The Dance of the Intellect: Studies in the Poetry of the Pound Tradition. New York: Cambridge UP, 1985.

Pound, Ezra. Guide to Kulchur. London: Peter Owen, 1966.

---. Literary Essays. Ed. T.S. Eliot. New York: New Directions, 1968.

---. Personae: The Shorter Poems. Eds. Lea Beachler and A. Walton Litz. New York: New Directions, 1990.

Ramazani, Jahan. The Hybrid Muse: Postcolonial Poetry in English. Chicago: U of Chicago P, 2001.

Rich, Adrienne. Introduction. The Work of a Common Woman. By Judy Grahn. 7-21. Rosenthal, M.L. and Sally Gall. Modern Poetic Sequence: The Genius of Modern Poetry. New York: Oxford UP, 1986.

Rothenberg, Jerome. Technicians of the Sacred: A Range of Poetries from Africa, America, Asia, and Oceania. Garden City, NY: Doubleday, 1968.

Rothenberg, Jerome and Pierre Joris. Poems for the Millennium: Volume One. Berkeley: U of California P, 1995.

Ruskin, John. Fors Clavigera: Letters to the Workmen and Labourers of Great Britian, Volume I. Boston: Dana Estes \& Company, n.d.

Said, Edward W. Beginnings: Intention and Method. New York: Columbia UP, 1985. ---. Culture and Imperialism. New York: Vintage, 1993.

---. Orientalism. New York: Vintage, 1978.

Salvato, Nick. "Louis Zukofsky's Old English Sources for 'A'-23." Notes and Queries 
49.1 (March 2002): 85-88.

Sampietro, Luigi. Derek Walcott on “Omeros": An Interview. 7 May 2003.

$<$ http://users.unimi.it/caribana/OnOmeros.html $>$.

Schwerner, Armand. The Tablets. Orono, ME: The National Poetry Foundation, 1999.

Scroggins, Mark. Louis Zukofsky and the Poetry of Knowledge. Tuscaloosa: U of Alabama P, 1998.

Sherry, Vincent. The Uncommon Tongue: The Poetry and Criticism of Geoffrey Hill. Ann Arbor: U of Michigan P, 1987.

Shetley, Vernon. After the Death of Poetry: Poet and Audience in Contemporary America. Durham: Duke UP, 1993.

Spencer, Philip and Howard Wollman. Nationalism: A Critical Introduction. London: Sage Publications, 2002.

Spivak, Gayatri Chakravorty. “Can the Subaltern Speak?” Ashcroft et al 24-28.

Stenton, Frank. Anglo-Saxon England. 3rd Ed. New York: Oxford UP, 2001.

Stone, Merlin. When God Was a Woman. New York: Harvest, 1976.

Storey, John. Inventing Popular Culture: From Folklore to Globalization. Malden, MA: Blackwell, 2003.

Sword, Helen. "James Merrill, Sylvia Plath, and the Poetics of Ouija." American Literature 66 (September 1994): 553-572.

Thieme, John. Derek Walcott. New York: Manchester UP, 1999.

Torgovnick, Marianna. Gone Primitive: Savage Intellects, Modern Lives. Chicago: U of Chicago P, 1991. 
Tytell, John. Ezra Pound: The Solitary Volcano. New York: Anchor P, 1987.

Vickery, John B. "Frazer and the Elegiac: The Modernist Connection." Modernist Anthropology: From Fieldwork to Text. Ed. Marc Manganaro. Princeton: Princeton UP, 1990. 51-68.

Virgil. The Aeneid. Trans. Allen Mandelbaum. New York: Bantam, 1971.

Walcott, Derek. Collected Poems: 1948-1984. New York: Farrar, Straus and Giroux, 1986.

---. Omeros. New York: Noonday, 1990.

---. What the Twilight Says. New York: Farrar, Straus and Giroux, 1998.

Walker, Jeffrey. Bardic Ethos and the American Epic Poem: Whitman, Pound, Crane, Williams, Olson. Baton Rouge: Louisiana State UP, 1989.

Weil, Simone. "The Iliad"; or the Poem of Force: A Critical Edition. Trans. and Ed. James P. Holoka. New York: Peter Lang, 2003.

Wormald, Patrick. "The Age of Offa and Alcuin." The Anglo-Saxons. Ed. James Campbell. New York: Penguin, 1991. 101-131.

Yeats, William Butler. The Yeats Reader: A Portable Compendium of Poetry, Drama, and Prose. Ed. Richard J. Finneran. New York: Scribner, 1997.

Zukofsky, Louis. “A.” Baltimore: Johns Hopkins UP, 1978. 


\section{Joe W. Moffett}

West Virginia University

Department of English

230 Stansbury Hall

P.O. Box 6296

Morgantown, WV 26506

jmoffett@mix.wvu.edu
1201 Milton Street

Morgantown, WV 26505

(304) 292-7781

jkdmoffett@aol.com

\section{Education}

$\mathrm{PhD}$ in English, West Virginia University, May 2004

Dissertation: Origins and the Twentieth-Century Long Poem

Director: Brian McHale

MA in English, West Virginia University, August 2000

Thesis: Carnivalized Narratives in the Postmodern Long Poem

BA in English, Pennsylvania State University, Behrend College, May 1998

Thesis: "Back to the Geography of It": Olson's Reaction to Place in The

Maximus Poems

\section{Academic Awards and Activities}

2003-2004 Stephen F. Crocker Dissertation Fellowship

1998-2003 Stephen F. Crocker Scholarship

1999 Participant in West Virginia Writers' Workshop

1998 Second place, Kenneth Sonnenberg Poetry Award

1997 Undergraduate Summer Research Grant

1997-1998 Eugenie Bauman Smith Creative Writing Scholarship

1993-1994 Contributing Writer on Penn State-Beaver's Campus Newspaper

\section{Teaching Experience}

Research and Argumentative Writing (English 102): Summer 2002-Summer 2003 (four sections)

Designed and conducted courses which focused on students developing research skills and practicing forms of argumentation

Business and Professional Writing (English 202): Spring 2003 (one section)

Designed and taught a portfolio-driven course with an emphasis on analyzing and practicing forms of business writing

Tutoring: Fall 2002

Tutored both regularly scheduled students from English courses as well as drop-in student from other disciplines 
Freshman Composition and Rhetoric (English 101): Fall 1998-Spring 2002 (eleven sections)

Conducted portfolio-driven composition courses which emphasized collaborative work in the form of peer reviews and group conferencing

\section{Publication}

"Charles Olson." Who's Who in Twentieth-Century World Poetry. Eds. Mark Willhardt and Alan Michael Parker. New York: Routledge, 2002.

\section{Professional Presentations}

"Representations of the Witch in Jacobean Drama: The Case of The Witch of Edmonton," West Virginia Shakespeare and Renaissance Association (WEVSARA), Morgantown, WV, Apr. 19-20, 2002

"Olson's Maximus, Schwerner's Tablets, and the Shift from Modernist to Postmodernist Long Poem," WVU-CMU Graduate Student Colloquium, Morgantown, WV, Mar. 15-16, 2002

"The Dialogics of James Merrill's The Changing Light at Sandover," The West Virginia Association of College English Teachers (WVACET), North Bend State Park, WV, Oct. 15-16 1999

“"Making a Mappemunde': Space and Ontology in The Maximus Poems," WVU Graduate Student Colloquium, Morgantown, WV, Feb. 26-27, 1999

"From the Imaginary to the Symbolic: The Monster's Acquisition of Language in Frankenstein," The Pennsylvania College English Association (PCEA), Erie, PA, Apr. 17-19 1997

\section{Relevant Graduate Coursework}

Recent Literary Theory Postmodernism

American Literature 1915-Present American Studies Seminar: The Long Poem $20^{\text {th }}$-Century British Studies Contemporary American Poetry

Independent Study in $20^{\text {th }}$-Century British Poetry

\section{University Service}

Member, WVU-CMU Graduate Colloquium Steering Committee, 2002

Member, Undergraduate Writing Program Assessment Committee, 1999-2000

\section{Professional Affiliations}

Modern Language Association 
Charles Olson Society

The Modernist Studies Association

My dossier, containing my letters of recommendation and my transcript, is available from Career Services Center, West Virginia University, P.O. Box 6008, Morgantown, WV 26505-6008, (304) 293-2221. 